\title{
Butterfles (Lepidoptera) OF ChizAMi, PHeK District, NAGALAND, INDIA
}

\section{Tshetsholo Naro ${ }^{1} \&$ Sanjay Sondhi ${ }^{2}$}

${ }^{1}$ North East Network, P.O. Chizami, Phek District, Nagaland 797102, India

${ }^{2}$ Titli Trust, 49 Rajpur Road Enclave, Dhoran Khas, Dehradun, Uttarakhand 248001, India

${ }^{1}$ tshetsholo@gmail.com, ${ }^{2}$ sanjay.sondhi1@gmail.com (corresponding author)

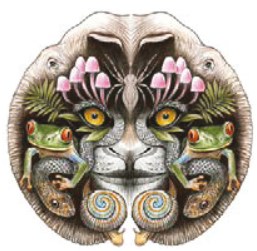

ISSN 0974-7907 (Online) ISSN 0974-7893 (Print)

OPEN ACCESS

Abstract: The butterflies of Chizami, Phek District of Nagaland, India were documented over a period of three years (2011-2014). This represents the first list of butterfly records from Nagaland after publications by Tytler between 1911 and 1914. Two-hundred-and-twelve (212) species were recorded of which 34 species are legally protected under various schedules of the Wildlife (Protection) Act, 1972. Amongst the many significant records during the survey, two species, the Tawny Emperor Chitoria ulupi ulupi and the Comic Oakblue Arhopala comica were recorded from India after a period of 100 years.

Keywords: Butterfly diversity, checklist, Chizami, Arhopala comica, inventory, Lepidoptera, Nagaland, record, Chitoria ulupi.
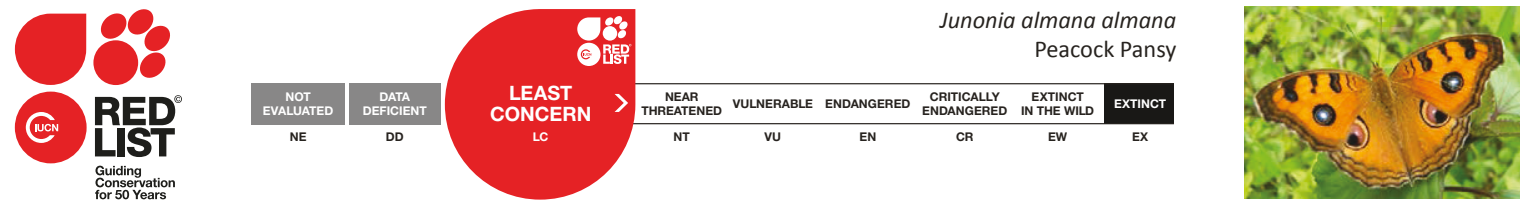

DOI: http://dx.doi.org/10.11609/JoTT.03995.6593-634 | ZooBank: urn:Isid:zoobank.org:pub:9D2FB576-3CEC-42A2-BE43-EE817DD23F00

Editor: Anonymity requested.

Date of publication: 12 December 2014 (online \& print)

Manuscript details: Ms \# 03995 | Received 12 April 2014 | Final received 16 October 2014 | Finally accepted 28 November 2014

Citation: Naro, T. \& S. Sondhi (2014). Butterflies (Lepidoptera) of Chizami, Phek District, Nagaland, India. Journal of Threatened Taxa 6(13): 6593-6634; http:// dx.doi.org/10.11609/JoTT.03995.6593-634

Copyright: @ Naro \& Sondhi 2014. Creative Commons Attribution 4.0 International License. JoTT allows unrestricted use of this article in any medium, reproduction and distribution by providing adequate credit to the authors and the source of publication.

Funding: The North East Network (NEN) with the support of EED \& Misereor, Germany (2010-March 2013) and Nagaland Wildlife and Biodiversity Conservation Trust (May 2013- December 2014) funded NEN's Conservation Education Programme and enabled Sanjay Sondhi's visit to Chizami and Tshetsholo Naro with the HGEC to do the study.

Competing Interest: The authors declare no competing interests.

Author Contributions: TN surveyed butterflies in the area from 2011 to 2014. TN and members of the HGEC took most of the photographs of this paper. SS made five visits to Chizami and surveyed butterflies during his visits. TN identified many of the species, and SS confirmed their identities. SS conducted the literature review. The paper was written jointly with both authors contributing their records. TN prepared the plates.

Author Details: TSHETSHOLO NARO (Alo) is a young nature conservationist based in Chizami, Phek District, Nagaland and currently working with an NGO, North East Network (NEN), in its Nature Conservation Education Programme which involves constant engagement with youths and children towards creating a consciousness for conservation. Alo has an enthusiastic interest in studying butterflies and has been identifying butterflies in and around Chizami since 2011; he also has keen interest in nature photography and videography. SANJAY SONDHI, Founder Trustee Titli Trust, is a naturalist with an interest in Lepidoptera, herpetofauna and avifauna. He supports conservation research and action and conservation education programs in eastern and western Himalaya.

Acknowledgements: TN thanks the North East Network for the opportunity they have given him to get involved in nature conservation education programme and in many other ways. SS acknowledges the support given to him by North East Network during his various visits to Nagaland. The authors would like to thank the reviewers for their feedback and comments.

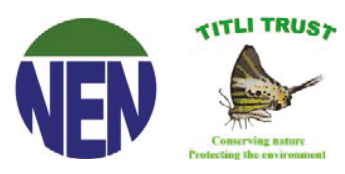




\section{INTRODUCTION}

The hill state of Nagaland has a geographical area of $16,579 \mathrm{~km}^{2}$ of which $30 \%$ is under forest with $88 \%$ of this being private forests. Nagaland falls in the eastern Himalaya region of the Himalaya Global Biodiversity Hotspot, one of 34 global biodiversity hotspots. Nagaland is home to a variety of forest types (altitudes vary from 184-3,841 m) varying from northern tropical wet evergreen forest, northern tropical semievergreen forest, northern sub-tropical broad-leaved wet hill forest $(500-1,800 \mathrm{~m})$, northern sub-tropical pine forest $(1,000-1,500 \mathrm{~m})$, northern montane wet temperate forest $(2,000-2,500 \mathrm{~m})$ and temperate forest (above 2,500m) (http://ibcn.in/wp-content/ uploads/2011/12/33-793_812- Nagaland.pdf).

Chizami is located in the Phek District in southeastern Nagaland. Phek District, covering an area of $2,026 \mathrm{~km}^{2}$ is bordered by Myanmar on the east and the state of Manipur on the south. To its north are Kiphire and Zunheboto districts, while Kohima District is to its west. The village of Chizami is $88 \mathrm{~km}$ due east of Kohima (Fig. $1)$.

It covers an area of 85,242 ha approximately and the altitudinal range varies from 981-2000 m. The forest type at Chizami is mainly sub-tropical pine forest and some northern sub-tropical broad-leaved wet hill forest. The Chakhesang tribe inhabits Chizami. Chizami village shares its boundary with Pholami villages on the north; Khomi, Sumi and Losami Village on the northeast; Lai Village of Manipur State on the east, Thetsumi Village on the south; Enhulumi Village on the west and Porba and Sakraba villages on the northwest. The Kuwari River is to the east and the Tuphale River to the west of Chizami.

North East Network (NEN) (www.northeastnetwork. org) is a women's rights organization working in the northeastern region of India with a focus on women's rights. NEN has also been working on the issue of natural resource management in the area. As part of the Natural Resource Management activity, wildlife and biodiversity conservation education programme was launched in 2010 and the Hoolock Gibbon Eco Club was formed. The Hoolock Gibbon Eco Club (HGEC) is a children's eco club consisting of 40 members from the villages of Chizami and Enhulumi between the age group of 10-14 years. The HGEC is focused on conservation education, conservation research and conservation action. As part of the HGEC's activities, primarily Tshetsholo Naro (TN), Kewekhrozo Thopi, NEN and Sanjay Sondhi (SS), Titli Trust (www.titlitrust.com), introduced the children to butterfly watching and identification. Quite a few of the records in this paper are through photographs taken by members of the HGEC.

\section{METHODS}

The authors conducted butterfly surveys in the area over a period of three years. The butterfly study was mainly conducted in the following areas (Fig. 2). (i) NEN compound $\left(25^{\circ} 24^{\prime} 0^{\prime \prime} \mathrm{N} \& 94^{\circ} 24^{\prime} \mathrm{E}, 1440 \mathrm{~m}\right)$; (ii) In and around Chizami Village; (iii) The road leading to Thetsumi Village approximately $5 \mathrm{~km}$ away from Chizami Village; (iv) The Ewelu path up to approximately $3 \mathrm{~km}$ from Chizami Village; (v) Erule River bank - a mini hydro project area $10 \mathrm{~km}$ away from Chizami Village. Areas that were primarily visited are listed below along with photographs of their habitats (Appendix 1).

More than $50 \%$ of the butterflies seen were in the NEN compound. TN lives in Chizami, and opportunistically recorded and photographed butterflies in the area beginning 2010. SS made five visits to Chizami in July 2011, February 2012, October 2012, January 2013

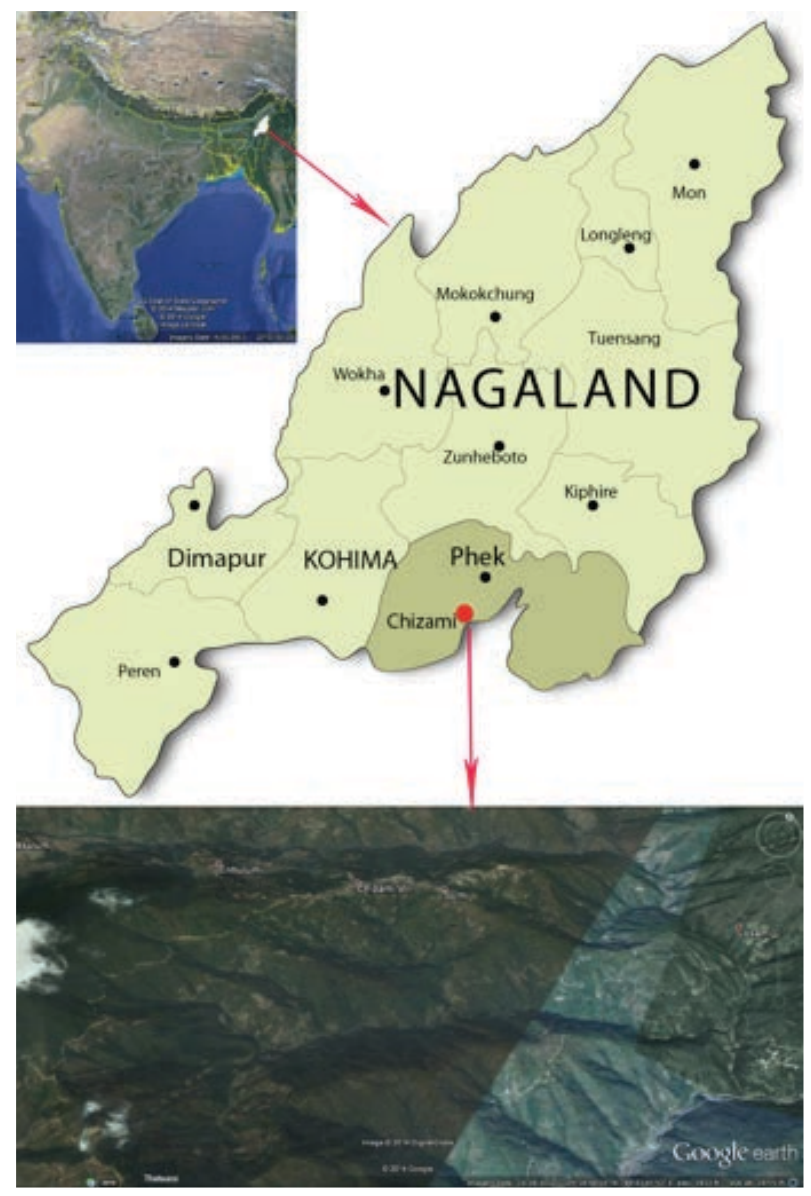

Figure 1. Map of Nagaland, Phek District, Chizami 


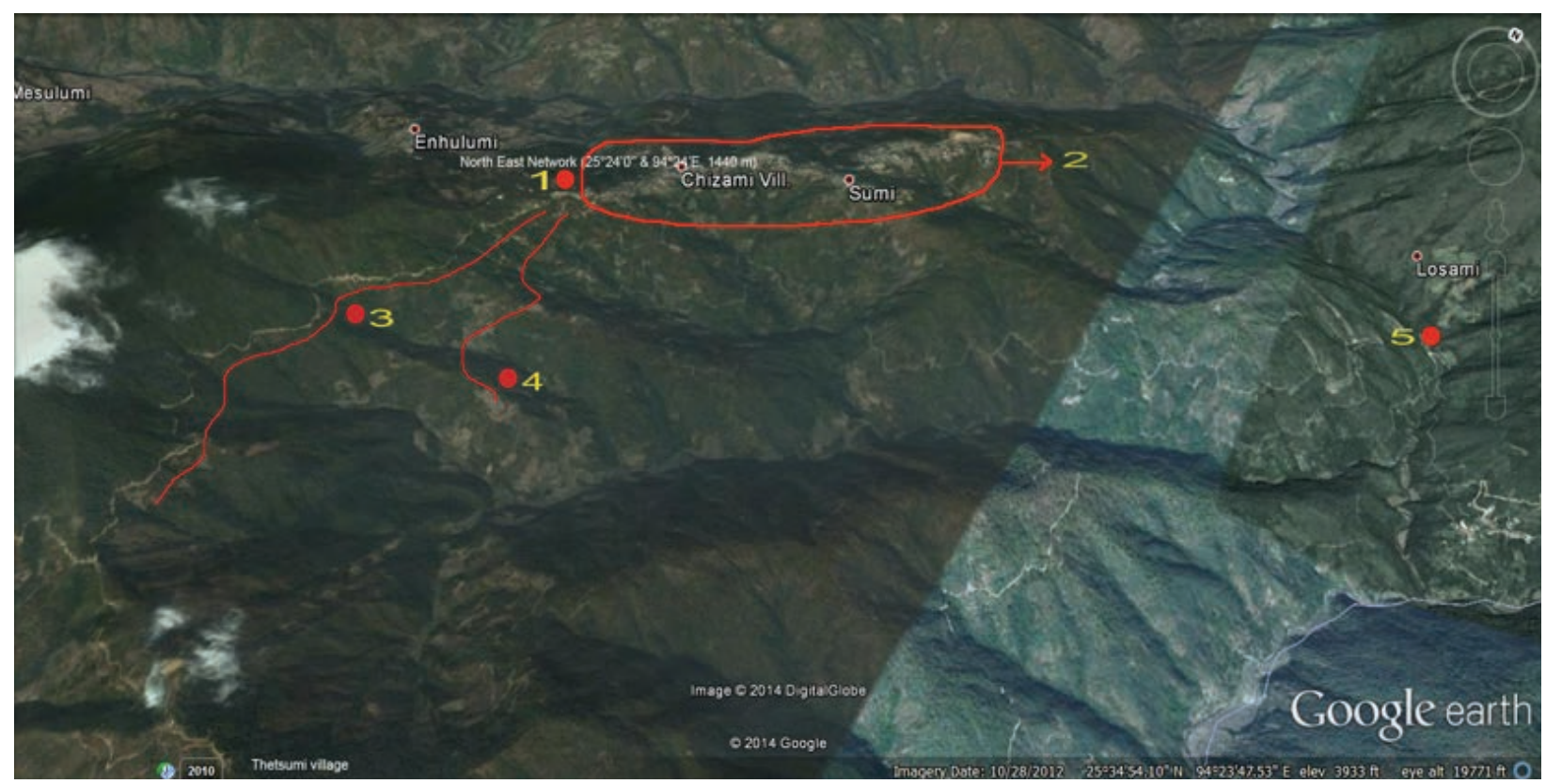

Figure 2. Map of Chizami and surrounding areas.

1 - NEN compound; 2 - In and around Chizami Village; 3 - Thetsumi Road; 4 - Ewelu path; 5 - Erule River.

and March 2013 during which he surveyed butterflies along with TN. The butterflies were photographed and identified using existing literature (Marshall 1882-90; Bingham 1905-07; Swinhoe 1912-13; Evans 1932, 1949; Talbot 1939, 1947; Wynter-Blyth 1957; Eliot 1969; Corbet et. al 1992; Haribal 1992; Smith 1993; Smith 1994; Kunte 2000; Kinyon 2004; Kehimkar 2008; Singh 2011; Sondhi et. al 2013; Sondhi \& Kunte 2014). Cryptic species were netted and their external features relevant for identification were observed and photographed. Wherever possible, the identification of the individuals were done up to the subspecies level. In numerous species, there are different common names in use. Alternate common names, if in use, are mentioned in brackets.

\section{RESULTS AND DISCUSSION}

Two-hundred-and-twelve (212) species were recorded during the survey. The family Nymphalidae with 102 species representing 48\% of the species seen was the most abundant family followed by Lycaenidae with 36 species (17\%) and Hesperiidae with 30 species (14\%). Of the 212 species recorded in Chizami, 34 species are legally protected under various schedules of the Wildlife (Protection) Act, 1972 (Table 1).

Surveys and collections of butterflies from the Naga Hills are scanty and Varshney's bibliography (Varshney $2008,2009)$ was consulted along with SS's perusal of older literature. Amongst the earliest publications on butterflies from the Naga Hills was the publication by Elwes on the collection of butterflies by Mr. W. Doherty during two expeditions in 1889 and 1890 (Elwes 1891). In 1889 , Doherty spent the rainy season collecting in the Naga Hills from June to September. Subsequent to Mr. Doherty's butterfly collection in the Naga Hills, Major H.C. Tytler spent many years collecting and reporting on the butterflies of the Naga Hills (Tytler 1911, 1912). Tytler's collection covered the lower, medium and higher altitudes of the Naga Hills covering areas between 200 and 2,100 $\mathrm{m}$. Later, Tytler, who had by then become a Lieutenant Colonel, was posted in Imphal in Manipur and further collected butterflies from Manipur and Naga hills (Tytler 1914, 1915a,b). In this paper, we will be referring to only these species recorded from the Naga Hills.

Amongst the significant records during the survey, two species, the Tawny Emperor Chitoria ulupi ulupi and the Comic Oakblue Arhopala comica have been recorded from India after 100 years, having last been recorded during surveys by Tytler (1915a,b). The Comic Oakblue Arhopala comica has previously only been known from a few specimens collected in Manipur, hence this record extends its range marginally to Nagaland. There are numerous others species and subspecies for which there exist no or very few recent published records from India such as Assam Darter Ochlodes siva siva, Purple Swift Caltoris tulsi, Ruddy Pied Flat Pseudocoladenia fatua, Khaki Silverline Spindasis rukmini, Hedge Cupid Bothrinia chennelli, Blue Duke Euthalia durga splendens, and 
Table 1. Species recorded from Chizami covered in WLPA schedules

\begin{tabular}{|l|l|}
\hline Schedule I & Nymphalidae \\
Lycaenidae & Aemona amathusia \\
Arhopala comica & Calinaga brahma brahma \\
Spindasis rukmini & Euthalia franciae franciae \\
& Euthalia aconthea garuda \\
Nymphalidae & Faunis eumeus assama \\
Bassarona durga splendens & Hestina persimilis persimilis \\
Chitoria ulupi ulupi & Parthenos sylvia gambrisius \\
Dilipia morgiana & Kallima knyvettii \\
Mimathyma chevana chevana & Lethe sinorix sinorix \\
Sephisa Chandra Chandra & Libythea lepita lepita \\
& Melanitis zitenius zitenius \\
Schedule II & Mycalesis mestra sadona \\
& Symbrenthia niphanda niphanda \\
Lycaenidae & Pieridae \\
Anthene lycaenina lycambes & Appias albina darada \\
Arhopala ganesa watsoni & \\
Bothrinia chennelli & Schedule IV \\
Euchrysops cnejus cnejus & Hesperiidae \\
Flos areste & Hyarotis adrastus praba \\
Heliophorus moorei tytleri & \\
Jamides elpis pseudoelpis & Nymphalidae \\
Lampides boeticus & Euploea mulciber mulciber \\
Poritia hewitsoni hewitsoni & Euthalia lubentina lubentina \\
& Pieridae \\
& Appias galba \\
\hline
\end{tabular}

Green Duke Euthalia sahadeva nadaka. These species are discussed in more detail in the notes below.

The present work is significant because it reports numerous species not recorded by Tytler and Elwes during their extensive collections of butterflies in the Naga Hills. Equally significant, there are more than a hundred species that were collected by them that were not recorded at Chizami, though the survey area and elevations covered during their surveys were far more extensive.

\section{NOTES ON THE BUTTERFLIES OF CHIZAMI}

\section{Family Hesperiidae, Subfamily Coeliadinae}

\section{Brown Awl Badamia exclamationis Fabricius, 1775}

Recorded from the NEN compound in June 2012 and July 2013 at the same location. Rare. Reported to be not uncommon at Kohima (Tytler 1912).

\section{Green Awlet Bibasis vasutana Moore, 1865}

Recorded from the NEN compound in October 2011. Rare. Reported from the Naga Hills (Elwes 1892). Reported to be common at Kohima (Tytler 1912).

\section{Indian Awlking Choaspes benjaminii japonica Murray, 1875}

Recorded from near the stream on the Thetsumi roadside at Chizami in July and November 2011. It should be noted that while this subspecies is the one that is most commonly recorded in northeastern India, species of this genera are best separated by examining male genitalia. Rare. Reported from the Naga Hills (Elwes 1892). Several individuals collected at Kohima (Tytler 1912).

\section{Slate Awl Hasora anura anura de Nicéville, 1889}

Recorded at NEN compound in November 2011. Very rare.

\section{White-banded Awl Hasora taminatus bhavara Fruhstorfer, 1911}

Recorded from the NEN compound in the month of July 2012. Rare.

\section{Family Hesperiidae, Subfamily Hesperiinae}

6. Blue-spotted Scrub Hopper Aeromachus kali de Nicéville, 1885

Recorded on the Chizami road leading to Enhulumi Village in May 2012. Rare. Reported to be common in the Naga Hills (Elwes 1892; Tytler 1912).

\section{Veined Scrub Hopper Aeromachus stigmata obsoleta Moore, 1878}

Recorded from the NEN compound and the Erule River at Chizami during the post-monsoon season. Uncommon. Reported from the Naga Hills (Elwes 1892; Tytler 1912).

\section{Forest Hopper Astictopterus jama olivascens Moore, 1878}

Recorded from the Erule River and the Thetsumi trail at Chizami between March and July in the pre-monsoon season. Common. Reported from the Naga Hills (Elwes 1892; Tytler 1912).

\section{Purple Swift Caltoris tulsi de Nicéville, $\mathbf{1 8 8 3}$}

Recorded from the NEN compound in late November 2011. Few recent published records from India. Rare.

\section{Straight Swift Parnara cf. guttatus Bremer \& Grey, 1852}

Recorded in the flower garden at NEN compound in August 2011 and October 2012. Members of this genus are best separated by male genitalia; hence this has only been provisionally identified. Common. Reported from the Naga Hills (Elwes 1892). Reported to be not common at Kohima (Tytler 1912). 


\section{Small Branded Swift Pelopidas mathias mathias} Fabricius, 1798

Recorded from the NEN compound in the flower garden in August 2011. Uncommon.

\section{Large Branded Swift Pelopidas sinensis Mabille,} 1877

Recorded from the NEN compound in the month of February 2012. Reported from the Naga Hills (Elwes 1892). Reported to be common at Kohima (Tytler 1912).

\section{Yellow Spot Swift Polytremis eltola eltola Hewitson, 1869}

Recorded from all locations at Chizami. Mostly seen during the pre- and post- monsoon seasons. Common. Reported to be common at Kohima (Tytler 1912).

\section{Dart spp. Potanthus spp.}

Numerous records from the Chizami area in the preand post-monsoon seasons. Numerous species reported from the Naga Hills (Elwes 1892).

\section{Assam Darter Ochlodes siva siva Moore, 1878}

Two individuals sighted by TN. Seen $400 \mathrm{~m}$ away from NEN office (West) in May 2010 and at the NEN compound in May 2014. The first individual was a female, lacking the UPF brand. However, UPH discal spots were as opaque as the opaque spots in space $1 \mathrm{~b}$ UPF and not hyaline as are the other spots UPF, separating it from Ochlodes brahma (Evans 1949). In addition, the spot in $1 b$ in 0 . brahma is much smaller. Rare. These are the first records of this species from Nagaland, having been recorded from Khasi Hills in Meghalaya, Mussoorie in Uttarakhand, Assam and north Myanmar (Evans 1949). These sightings are also the first published record of this species from India in many decades.

16. Light Straw Ace Pithauria stramineipennis stramineipennis Wood-Mason \& de Nicéville, 1886

Single record from Erule River bank at Chizami in August 2013. SS had observed this species in the foothills from other parts of northeastern India, while it has been recorded up to 640m in Nepal (Smith 1994), hence this record from $700 \mathrm{~m}$ is unusual. Very rare in the survey area. Reported from the Naga Hills at low elevations in March and October (Tytler 1912).

\section{Tufted Ace Sebastonyma dolopia Hewitson, 1868}

Recorded from the NEN compound in October 2012. Rare in the survey area. Reported from the Naga Hills (Tytler 1912).
18. Indian Palm Bob Suastus gremius gremius Fabricius, 1798

Single record from Erule River bank at Chizami in August 2013. Very rare in the survey area.

\section{Sikkim Palm Red-eye Erionota torus Evans, 1941}

Recorded from all locations at Chizami. Separated from similar-looking $E$. thrax by the rounded FW apex and convex termen, though it is pertinent to note that this species is best separated from E. thrax by male genitalia. Mostly seen during the pre-monsoon season. An individual entered the training room at night on two consecutive nights in July 2011, evidently attracted to light. Common. Erionota thrax reported from the Naga Hills with individuals captured at Kohima inside a bungalow, apparently attracted to light, just as we had observed (Tytler 1912). However, Evans described $E$. torus as a separate species from E. thrax only in 1941, hence Tytler's records could have been either of these two species.

\section{Black-veined Branded Red-eye Matapa cf. sasivarna Moore, 1865}

Recorded on the Chizami road leading to Thetsumi in October. The upperside of this individual was not observed. This species could be $M$. cresta, $M$. purpurascens or M. sasivarna. In the field, these species are best separated by a combination of the male UPF brands and wing markings and coloration. While in $M$. cresta and $M$. purpurascens the male brand is black and inconspicuous, in M. sasivarna, it is grey and conspicuous. However, on the basis of the absence of paler UNF apex and UNH base, present in $M$. cresta, and the metallicgreen scales at HW base and wing coloration, this is provisionally identified as M. sasivarna (de Jong 1983; Evans 1949). Very rare.

\section{Restricted Demon Notocrypta curvifascia curvifascia Felder \& Felder, 1862}

Recorded from all locations at Chizami. Mostly seen in the post-monsoon season. Common. Reported to be common at Kohima (Tytler 1911).

\section{Spotted Demon Notocrypta feisthamelii alysos Moore, 1865}

Recorded on the Chizami to Awelu trail near the stream in the pre-monsoon season. Uncommon. Reported to be common at Kohima (Tytler 1912). 
23. Common Banded Demon Notocrypta paralysos asawa Fruhstrofer, 1911

Single record from the NEN compound in July 2011. Rare in the survey area.

\section{Tree Flitter Hyarotis adrastus praba Moore, 1865}

Recorded on the Chizami to Erule trail in the premonsoon season. Uncommon. This subspecies is legally protected under Schedule IV of the Wildlife (Protection) Act, 1972. Reported from the Naga Hills (Tytler 1912).

\section{Family Hesperiidae, Subfamily Pyrginae}

25. Common Spotted Flat Celaenorrhinus leucocera Kollar, 1844

Worn individuals were recorded from the NEN compound in October 2012. Uncommon. Reported from the Naga Hills in September (Tytler 1912).

\section{Ruddy Pied Flat Pseudocoladenia cf. fatua Evans,} 1949

Recorded from the Thetsumi roadside near the stream and at the NEN compound in May and June. Rare. This species most closely resembles $P$. fatua with the spot in two extended to beyond origin of vein 3 , UPF, and being brighter, similar to the West Himalayan species $P$. fatih and its wings being more produced than $P$. festa which also occurs at similar altitudes (Evans 1949). The similar looking $P$. dan is more of a low elevation species. It is pertinent to note that while Evans (1949) had treated fatua and festa as a subspecies of Pseudocoladenia dan, subsequent work has elevated both these subspecies to species level (Huang \& Xue, 2004). However, P. fatua and $P$. festa are best separated by differences in male genitalia, hence this species is provisionally identified. Reported as Coladenia faith from Kohima in the Naga Hills in September and October between 1,800 and 2,130 $\mathrm{m}$ (Tytler 1915b), and possibly represents the species $P$. fatua as described by Evans (1949).

\section{Spotted Snow Flat Tagiades menaka menaka Moore, 1865}

Recorded from the NEN compound in October 2011. Rare. Reported from the Naga Hills (Elwes 1892; Tytler 1912).

28. Spotted Angle Caprona agama agama Moore, 1857 Recorded from the Erule River at Chizami in March 2012. Rare.
29. Tawny Angle Ctenoptilum vasava vasava Moore, 1865

Recorded from the Erule River at Chizami in March 2012. Rare. A single male collected from Nichuguard in the Naga Hills (Tytler 1912).

\section{Chestnut Angle Odontoptilum angulata angulata Felder, 1862}

Recorded from the Erule River at Chizami in March 2013. Rare in the survey area. Reported to be common from the Naga Hills at low elevations (Tytler 1912).

\section{Family Lycaenidae, Subfamily Curetinae}

31. Bright Sunbeam Curetis bulis bulis Westwood, 1851

Recorded two individuals at the NEN compound and on the Erule trail at Chizami in October 2012. Rare in the survey area. Reported from the Naga Hills (Elwes 1892; Tytler 1912).

\section{Family Lycaenidae, Subfamily Lycaeninae}

32. Golden Sapphire Heliophorus brahma brahma Moore, 1857

Recorded from all locations at Chizami, throughout the year, though less common in the winter months. Very common. Reported to be common in the Naga Hills (Elwes 1892; Tytler 1912).

\section{Naga Sapphire Heliophorus kohimensis kohimensis Tytler, 1912}

Recorded from only two locations at Chizami. On the Ezilu road to Enhulumi and around NEN compound. Both males and females seen at NEN compound. Seen from May to October. Uncommon. Described as a new species by Tytler from the Naga Hills (1911).

\section{Green Sapphire (Azure Sapphire) Heliophorus moorei tytleri Riley, 1929}

Recorded from the Government High school area and NEN compound. Very common. This species is legally protected under Schedule II of the Wildlife (Protection) Act, 1972. Reported as very abundant in the Naga Hills (Elwes 1892). Tytler (1911) reports it to be the most common of the genus in the Naga Hills.

\section{Family Lycaenidae, Subfamily Polyommatinae}

35. Pointed Ciliate Blue Anthene Iycaenina lycambes Hewitson, 1878

A single record from the Erule River at Chizami in July 2012. Seen mud-puddling at the riverside. Very rare in the survey area. This species is legally protected under Schedule II of the Wildlife (Protection) Act, 1972. 
Reported from the Naga Hills (Elwes 1892; Tytler 1912).

36. Common Hedge Blue Acytolepis puspa gisca Fruhstorfer, 1910

Recorded from all locations at Chizami. Very common. Reported to be very common from the Naga Hills (Elwes 1892; Tytler 1912).

\section{Plain Hedge Blue Celastrina lavendularis limbata} Moore, 1879

A single record by SS in July 2011. Very rare in the survey area. Reported from the Naga Hills (Elwes 1892).

\section{Pale Hedge Blue Udara dilecta dilecta Moore, 1879} Recorded from the NEN compound and Erule River at Chizami. Only two individuals seen in October 2011. Rare in the survey area. Reported from the Naga Hills (Elwes 1892).

\section{Hedge Cupid Bothrinia chennelli de Nicéville, 1884}

Recorded from the Erule trail at Chizami. Seen in October 2011 (TN) and March 2013 (SS). Rare. This species is legally protected under Schedule II of the Wildlife (Protection) Act, 1972. Reported from the Naga Hills (Elwes 1892). Reported to be not common by Tytler (1911).

\section{Chapman's Cupid Everes argiades diporides} Chapman, 1909

Single record from the NEN compound at Chizami in the month of October 2011. Very rare in the survey area. Reported from the Naga Hills (Elwes 1892; Tytler 1912).

41. Indian Cupid Everes lacturnus assamica Tytler, 1915 Recorded from the Erule River and the NEN compound in the pre- and post-monsoon seasons. Rare in the survey area. Reported from the Naga Hills (Tytler 1912).

\section{Silver Forget-me-not Catochrysops panormus exiguus Distant, 1886}

Recorded from two locations at Chizami; the NEN compound and on the Erule trail. Seen mostly during summer. Rare in the survey area. Reported from the Naga Hills (Tytler 1912).

43. Forget-me-not Catochrysops strabo strabo Fabricius, 1793

Recorded from the NEN compound. Two individuals seen. Rare in the survey area. Reported from the Naga Hills (Elwes 1892; Tytler 1912).
44. Gram Blue Euchrysops cnejus cnejus Fabricius, 1798

A single record from the NEN compound at Chizami in May 2012. Very rare in the survey area. This species is legally protected under Schedule II of the Wildlife (Protection) Act, 1972.

45. Dark Cerulean Jamides bochus bochus Stoll, 1782 Recorded from all locations at Chizami. Mostly seen in May. Very common. Reported from the Naga Hills (Elwes 1892; Tytler 1912).

\section{Cerulean Jamides species in DSF}

A butterfly was observed by TN at Chizami in November 2012, which looked like a Jamides in DSF and could not be identified to the species level. The upperside markings were not observed in the field. This individual looked superficially like J. celeno in DSF, but the UNH discal markings were narrower and broken, somewhat like a Nacaduba species, compared with individuals observed by SS in other areas of the Himalayas.

\section{Glistening Cerulean Jamides elpis pseudoelpis Butler, 1879}

Recorded at Chizami near the village (east of Chizami). A single record in the month of January 2011. Very rare in the survey area. This species is legally protected under Schedule II of the Wildlife (Protection) Act, 1972. Reported to be common from the Naga Hills (Elwes 1892; Tytler 1912).

\section{Pea Blue Lampides boeticus Linnaeus, 1767}

Recorded from all locations at Chizami. Most common in the pre-monsoon season. Visits flowers. Very common. This species is legally protected under Schedule II of the Wildlife (Protection) Act, 1972. Reported to be very common from the Naga Hills (Tytler 1912).

\section{Zebra Blue Leptotes plinius plinius Fabricius, 1793}

Recorded from all locations at Chizami in April and May. Common. A single individual collected at Kohima (Tytler 1912).

\section{Dingy Lineblue Petrelaea dana de Nicéville, 1883}

A single record from the Erule riverside at Chizami in October 2011. Very rare in the survey area. Reported from the Naga Hills (Tytler 1912).

51. Common Lineblue Prosotas nora ardates Moore, 1874

Mostly recorded from the Erule riverside, mud- 
puddling in groups in the summer. Very common. Reported sparingly from $600 \mathrm{~m}$ altitude in the Naga Hills (Tytler 1912).

\section{Dark Grass Blue Zizeeria karsandra Moore, 1865}

Recorded from the NEN compound. Mostly seen during summer. Common. Reported from the Naga Hills (Tytler 1912).

\section{Family Lycaenidae, Subfamily Poritiinae}

53. Common Gem Poritia hewitsoni hewitsoni Moore, 1865

Recorded at Government High School area, Tahulu trail at Chizami. Recorded two individuals at different locations in the month of June 2012. This subspecies is legally protected under Schedule II of the Wildlife (Protection) Act, 1972. Rare. A few individuals collected from Kohima (Tytler 1912).

\section{Family Lycaenidae, Subfamily Theclinae}

54. Leaf Blue Amblypodia anita dina Fruhstrofer, 1907

This species was recorded on the Erule trail and mostly seen mud-puddling near the riverside. Subspecies level identity could not be confirmed; this could also be the ssp. gigantea, known from Manipur. Rare.

55. Bi-spot Royal Ancema ctesia ctesia Hewitson, 1865

A single record from the NEN compound in September 2013. Very rare in the survey area. Reported to be common at 1,500m in the Naga Hills (Tytler 1912).

\section{Powdered Oakblue Arhopala bazalus teetsa de Nicéville, 1886}

A single record from NEN compound in November 2013. Very rare in the survey area. Reported from the Naga Hills (Elwes 1892).

\section{Comic Oakblue Arhopala comica de Nicéville, 1900}

Two records by TN from the NEN compound on 1 April 2013 and 12 April 2014. Very rare. This Arhopala species is easily told by the markings on the underside as well as the shape of the hindwing tornus and its tail (de Nicéville, 1900). The type locality of this species is Bhamo in Myanmar while it was recorded as Surendra learmondi (=Arhopala comica) from Loimwe in the Southern Shan States (Tytler, 1940). From India, two females of this species were recorded from Sebong, Manipur in March (Tytler 1915b; Evans 1957). Hence this record of Arhopala comica marginally extends the range of this species into Nagaland, and is the first record from India in a hundred years, since Tytler's (1915b) collection in Manipur. This species is legally protected under Schedule I of the Wildlife (Protection) Act, 1972. Rare.

58. Tailless Bushblue Arhopala ganesa watsoni Evans, 1912

A single record from the Thetsumi roadside at Chizami in January 2013. Very rare in the survey area. This species is legally protected under Schedule II of the Wildlife (Protection) Act, 1972.

59. Yellowdisc Oakblue Arhopala singla de Nicéville, 1885

Single record from the New Town area at Chizami in September 2013. Very rare in the survey area. Reported from the Naga Hills (Elwes 1892; Tytler 1912).

\section{Tailless Plushblue Flos areste Hewitson, 1862}

Recorded from the NEN compound and the Erule trail at Chizami in November 2011 and January 2013. Four individuals sighted. Rare. This species is legally protected under Schedule II of the Wildlife (Protection) Act, 1972.

\section{Common Tinsel Catapaecilma major major Druce,} 1895

Recorded only once at the Erule riverbank at Chizami in March 2013. Very rare in the survey area. Reported from the Naga Hills (Tytler 1912).

62. Silverstreak Blue Iraota timoleon timoleon Stoll, 1790

Recorded two individuals from the NEN compound in May 2013. Very rare in the survey area. Reported from the Naga Hills in May (Tytler 1915b).

\section{Common Flash Rapala nissa nissoides Swinhoe, 1915}

Recorded from the NEN compound and the Erule trail in the pre-monsoon season from February to July. Rare. Reported from the Naga Hills (Elwes 1892) where it is not as common as in the Khasi Hills. Tytler (1911) reports it to be very common in Kohima throughout the year.

64. Khaki Silverline Spindasis rukmini de Nicéville, 1888 Recorded from the North East Network office compound. Single sighting in October 2012. Very rare. This species is legally protected under Schedule I of the Wildlife (Protection) Act, 1972. A single individual collected from the Naga Hills (Tytler 1912). 
65. Club Silverline Spindasis syama peguanus Moore, 1884

Recorded from the Government High school area and on the Erule trail at Chizami in the pre-monsoon season. Rare in the survey area. Reported from the Naga Hills (Elwes 1892; Tytler 1912).

66. Common Acacia Blue Surendra quercetorum quercetorum Moore, 1857

Recorded from many different locations at Chizami through most of the year. Very common. Reported from the Naga Hills (Elwes 1892; Tytler 1912).

Family Nymphalidae, Subfamily Apaturinae

67. Purple Emperor Apatura ambica ambica Kollar, 1844

Recorded from the Thetsumi trail and Erule riverside at Chizami. Seen sitting in groups, mud-puddling. Common. Reported to be common in the Naga foothills up to $1,370 \mathrm{~m}$ (Tytler 1911).

68. Tawny Emperor Chitoria ulupi ulupi Doherty, 1889

Recorded by TN from the NEN compound on 14 June 2013 at 12:57hr. Seen sitting on human clothes. This species is a powerful flier. There have been no published records of this species from India in more than a hundred years, having been last reported from India in 1915 (Tytler 1915a). Very rare. The subspecies florenciae, which is now synonymized with subspecies ulupi, is legally protected under Schedule I of the Wildlife (Protection) Act, 1972. Reported to be rare in the Naga Hills (Tytler 1911, 1915a). Tytler (1911) initially believed this to be a separate species from $C$. ulupi but later stated (Tytler 1915a) that it would turn out to be a race of the same species.

69. Golden Emperor Dilipia morgiana Westwood, 1850

Recorded from the Thetsumi trail and the Erule riverside at Chizami in October 2012 and August 2013 respectively. Common. Seen visiting an animal shed. This species is legally protected under Schedule I of the Wildlife (Protection) Act, 1972. Reported to be rather rare in the Naga hills (Tytler 1911).

\section{Sergeant Emperor Mimathyma chevana chevana} Moore, 1865

Only two individuals recorded from the NEN compound and Erule riverside at Chizami in October 2012. Rare. This subspecies is legally protected under Schedule I of the Wildlife (Protection) Act, 1972. A single individual recorded from the Naga Hills (Tytler 1911).
71. Courtesan Euripus nyctelius nyctelius Doubleday, 1845

Recorded from Khili and inside the village at Chizami in September and October 2011 respectively. Uncommon. Reported to be common in the Naga Hills (Tytler 1911).

72. Pasha Herona marathus marathus Doubleday, 1848 A single record from Sitikho at Chizami in October 2011. Rare.

\section{Circe Hestinalis nama nama Doubleday, 1844}

Recorded from many different locations at Chizami in the pre- and post-monsoon seasons. Very common. Reported to be very common in the Naga Hills (Tytler 1911).

\section{Siren Hestina persimilis persimilis Westwood, 1850}

Two individuals recorded from NEN compound and Chizami village in Aug 2011 and July 2013 respectively. This species is legally protected under Schedule II of the Wildlife (Protection) Act, 1972. Rare. A single individual recorded in October in the Naga Hills (Tytler 1911).

\section{Black Prince Rohana parisatis parisatis Westwood, 1850}

Recorded from the Erule riverside at Chizami in October 2012. Seen sitting on moist stones and mudpuddling. Common. Males reported to be exceedingly common in the Naga Hills (Tytler 1911).

\section{Eastern Courtier Sephisa chandra chandra Moore,} 1857

Recorded from two locations at Chizami-the Thetsumi trail and the Erule riverside in October 2011 and October 2012. Rare. This subspecies is legally protected under Schedule I of the Wildlife (Protection) Act, 1972. Numerous records from the Naga Hills (Tytler 1911).

Family Nymphalidae, Subfamily Biblidinae

77. Angled Castor Ariadne ariadne pallidior Fruhstorfer, 1899

Recorded by SS from Chizami in October 2012. Rare in the survey area.

\section{Common Castor Ariadne merione tapestrina Moore, 1884}

A single record from Etsoshulu at Chizami in October 2012. Very rare in the survey area. Only one individual collected from the Naga Hills (Tytler 1911). 
Family Nymphalidae, Subfamily Charaxinae

79. Common Nawab Charaxes athamas athamas Drury, 1770

Recorded from the Erule riverside at Chizami. Seen mud-puddling during the summer. Uncommon. Reported to be common from the Naga Hills up to 1,500m (Tytler 1911).

\section{Great Nawab Charaxes eudamippus eudamippus} Doubleday, 1843

Recorded two individuals from NEN compound and Erule riverside at Chizami in August 2011 and August 2013. Rare. Reported to be not uncommon in the Naga foothills (Tytler 1911).

Family Nymphalidae, Subfamily Cyrestinae

81. Common Map Cyrestis thyodamas thyodamas Boisduval, 1836

Recorded by SS in January 2013, but no photographic evidence. Rare in the survey area. Only a single individual collected, not common in the Naga Hills (Tytler 1911).

\section{Family Nymphalidae, Subfamily Danainae}

82. Plain Tiger Danaus chrysippus chrysippus Linnaeus, 1758

Records by SS in flight at Chizami in July 2011 and October 2012. Outside of Chizami, recorded by TN at Pungro, Kiphire District, Nagaland in the month of October 2013 where he sighted 2-3 individuals. Rare in the survey area. A few individuals reported from the foothills of the Naga Hills (Tytler 1911).

83. Striped Tiger (Common Tiger) Danaus genutia genutia Cramer 1779

Recorded from all locations at Chizami. Mostly seen during summer. Common. Reported from the Naga Hills from the foothills up to $1,500 \mathrm{~m}$ throughout the year (Tytler 1911).

\section{Striped Blue Crow Euploea mulciber mulciber Cramer, 1777}

Males and females recorded from the NEN compound and the Thetsumi trail at Chizami in the preand post-monsoon seasons. Uncommon. This species is legally protected under the Schedule IV of the Wildlife (Protection) Act, 1972. Reported as very common in the Naga Hills (Tytler 1911).

\section{Glassy Tiger Parantica aglea melanoides Moore, 1883}

Single record on the road linking Kuwari and Chizami.
Rare in the survey area. Reported to be common near Kohima from August to October (Tytler 1911).

86. Chocolate Tiger Parantica melaneus plataniston Fruhstorfer, 1910

Recorded from many different locations at Chizami. Common. Reported to be not common; collected near Kohima from August to October (Tytler 1911).

\section{Chestnut Tiger Parantica sita sita Kollar, 1844}

Recorded from many different locations at Chizami. Common. Reported to be common near Kohima from August to October (Tytler 1911).

\section{Dark Blue Tiger Tirumala septentrionis septentrionis Butler, 1874}

Recorded from all locations at Chizami between April and October. Common. Reported to be common; collected near Kohima from August to October and in the foothills in February and March (Tytler 1911).

\section{Family Nymphalidae, Subfamily Heliconiinae}

89. Yellow Coster Acraea issoria issoria Hübner, 1818

Recorded from many different locations at Chizami. Mostly seen during the summer. Very common. Reported to be very common from the Naga Hills in the post-monsoon season (Tytler 1911).

\section{Large Silverstripe Argynnis childreni childreni Gray,} 1831

Recorded from all locations at Chizami between March and October. Visits flowers. Very common. Reported to be fairly common from the Naga Hills (Tytler 1911).

91. Tropical Fritillary (Indian Fritillary) Argynnis hyperbius hyperbius Linnaeus, 1763

Recorded from all locations at Chizami. Both males and females (less common) seen between March and October. Common. Reported to be very common from the Naga Hills (Tytler 1911).

92. Red Lacewing Cethosia biblis tisamena Fruhstorfer, 1912

Recorded from all locations at Chizami between March and October. Very common. Reported to be exceedingly common from the Naga Hills (Tytler 1911).

93. Leopard Lacewing Cethosia cyane cyane Drury, 1770 Recorded from many different locations at Chizami. Mostly seen visiting flowers during summer. Uncommon. 
Reported to be not common from the Naga Hills (Tytler 1911).

94. Large Yeoman Cirrochroa aoris aoris Doubleday, 1847

Recorded from many different locations at Chizami between March and October. Seen visiting animal droppings and flowers. Common. Reported to be not very common from the Naga Hills (Tytler 1911).

\section{Common Yeoman Cirrochroa tyche mithila Moore, 1872}

Single record from the NEN compound in November 2011. Rare in the survey area. Reported to be not uncommon from the Naga Hills (Tytler 1911)

\section{Rustic Cupha erymanthis lotis Sulzer, 1776}

Single record from Kuwari at Chizami in November 2013. Very rare in the survey area. Reported to be rather scarce from the Naga Hills (Tytler 1911).

\section{Common Leopard Phalanta phalantha phalantha Drury, 1773}

Recorded from the NEN compound and the Erule riverside at Chizami. Two records from these two locations, seen during the pre-monsoon season. Rare in the survey area. Reported to be common from the Naga Hills (Tytler 1911).

\section{Vagrant Vagrans egista sinha Kollar, 1844}

Recorded from the Erule riverside at Chizami in the summer months. Seen visiting animal droppings and mud-puddling. Rare in the survey area. Reported to be common at low elevations from the Naga Hills (Tytler 1911).

\section{Cruiser Vindula erota erota Fabricius, 1793}

Recorded from Chizami. Both males and females (less common) seen between March and October. Seen visiting flowers. Uncommon. Males reported to be fairly common from the Naga Hills (Tytler 1911).

Family Nymphalidae, Subfamily Libytheinae

100. Common Beak Libythea lepita lepita Moore, 1857

Two individuals recorded from the NEN compound and the Erule River at Chizami in October 2012. Rare in the survey area. This species is legally protected under Schedule II of the Wildlife (Protection) Act, 1972. A few individuals collected from the Naga Hills (Tytler 1911).
Family Nymphalidae, Subfamily Limenitidinae 101. Himalayan Sergeant Athyma opalina orientalis Elwes, 1888

Several individuals recorded from two locations at the Thetsumi roadside at Chizami between March and October. Uncommon. Reported to be not uncommon from the Naga Hills (Elwes 1891; Tytler 1911).

\section{Common Sergeant Athyma perius perius Linnaeus,} 1758

Recorded from all locations at Chizami between March and October. Common. Reported to be very common from the Naga Hills (Tytler 1911).

\section{Orange Staff Sergeant Athyma cama cama Moore,} 1857

Recorded from the NEN compound in October 2012. Both male and female seen. Rare. Reported to be not uncommon from the Naga Hills (Tytler 1911).

104. Staff Sergeant Athyma selenophora selenophora Kollar, 1844

Two records from the NEN compound and the Erule trail at Chizami in October 2011. Rare. Reported to be very common from the Naga Hills (Tytler 1911).

\section{Freak Calinaga brahma brahma Butler, 1885}

Recorded from the NEN compound. Two individuals seen at the same location in May 2011 and March 2012. Rare. This species is legally protected under Schedule II of the Wildlife (Protection) Act, 1972. A few individuals collected in April and May, near Kohima (Tytler 1911).

\section{Blue Duke Bassarona durga splendens Tytler, 1915}

Recorded from Kuwari at Chizami in November 2013. Seen mud-puddling at the riverside. This is the rare subspecies splendens in which the blue discal band forms lunules throughout its length from tornus to costa described by Tytler (1915a) from the Naga Hills. Very rare. This species is legally protected under Schedule I of the Wildlife (Protection) Act, 1972. Reported from near Imphal in Manipur (Tytler 1915a).

\section{French Duke Euthalia franciae franciae Felder \&} Felder, 1859

Mostly recorded from the Thetsumi trail at Chizami. Common between July and October. This species is legally protected under Schedule II of the Wildlife (Protection) Act, 1972. Reported from the Naga Hills (Elwes 1891). It is reported to be not uncommon in August to October between 1,500-1,600 m in the Naga 
Hills (Tytler 1911).

108. Bronze Duke Euthalia nara nagaensis Tytler, 1940

A single record on the village footpath leading to the NEN office in September 2012. Very rare. Reported from the Naga Hills (Elwes 1891; Tytler 1911).

\section{Green Duke Euthalia sahadeva nadaka Fruhstorfer,} 1913

A male recorded basking high up on a tree in July 2011, below the NEN compound. Females recorded in the summer in the NEN compound. Common. Reported to be not uncommon from the Naga Hills (Elwes 1891; Tytler 1911; Tytler 1915a).

\section{Common Baron Euthalia aconthea garuda Moore,} 1857

Recorded from many different locations at Chizamiboth males and females seen. Recorded in the pre- and post-monsoon seasons. Common. This species is legally protected under Schedule II of the Wildlife (Protection) Act, 1972. Reported to be not common from the Naga Hills (Tytler 1911).

\section{Gaudy Baron Euthalia lubentina lubentina Cramer,} 1777

A single record from the Chizami Village in March 2012. Very rare in the survey area. This species is legally protected under Schedule IV of the Wildlife (Protection) Act, 1972. Only a few individuals collected in the Naga Hills (Tytler 1911).

112. White-edged Blue Baron Euthalia phemius phemius Doubleday, 1848

A single record of a male from the NEN compound in October 2011. Very rare in the survey area. Reported from the Naga Hills (Tytler 1911).

113. Yellow Sailer Neptis ananta ochracea Evans, 1924

Two individuals recorded from the Thopfu trail and the NEN compound in Sep 2013. Rare in the survey area. Reported to be not uncommon in the Naga Hills from July to October (Tytler 1911).

114. Namba Sailer Neptis cf. namba namba Tytler, 1915

A single unconfirmed record from the NEN compound in Oct 2011. Generally N. namba has brighter orange markings compared with $N$. ananta (Eliot, 1969), but this is not always true based on SS's experience in the field as well as images available online http://www. ifoundbutterflies.org/2773-Neptis/Neptis-namba and
http://www.ifoundbutterflies.org/2770-Neptis/Neptisananta wherein some individuals of $N$. namba have paler orange markings. While this individual was worn, and its cilia not clearly visible, the UNF/H bluish tinge on the markings below, so typical of namba was clearly visible hence we are inclined to provisionally identify this as $N$. namba. Neptis namba and Neptis ananta have often been considered as a single species and forms/subspecies of the latter. While Eliot suggested these were separate species, he also stated "dissections of the male genitalia have not helped greatly to establish whether there are one, two or three species in the complex." Clearly more work on the phylogeny and ecology of these species are necessary to establish their true status. Neptis namba was described by Tytler (1915a) as a new species on the basis of his collection from the Naga Hills. Tytler (1915a) states that $N$. ananta is mostly found between 1,500$2,100 \mathrm{~m}$, while $N$. namba is mostly found in the foothills. However, SS's records from the NE India show that while $N$. ananta is generally found at higher altitudes, both species have been recorded from the foothills at least up to $600 \mathrm{~m}$. However this record, if correct, extends its altitudinal range even further.

\section{Broad-banded Sailer Neptis sankara amba Moore, 1858}

Two individuals recorded from NEN compound in June 2012 and August 2012. Rare.

\section{Pallas's Sailer Neptis sappho astola Moore, 1872}

Recorded from all locations at Chizami between March and October. Very common. Reported to be very common from the Naga Hills (Tytler 1911).

117. Commander Moduza procris procris Cramer, 1777

A single record in flight by TN from the Erule River at Chizami in 2012. Very rare in the survey area.

118. Clipper Parthenos sylvia gambrisius Fabricius, 1787

A single record from the NEN compound in November 2011. Very rare in the survey area. This species is legally protected under Schedule II of the Wildlife (Protection) Act, 1972. Reported to be fairly common at low elevations in the Naga Hills (Tytler 1911).

\section{Family Nymphalidae, Subfamily Nymphalinae}

119. Indian Tortoiseshell Aglais caschmirensis aesis Fruhstorfer, 1912

Recorded from many different locations at Chizami in the pre- and post-monsoon seasons. Common. This species has extended its range eastwards over time from 
the western and central Himalaya and has established a known population in western Arunachal Pradesh and Nagaland (Naro 2012).

\section{Mongol Araschnia prorsoides dohertyi Blanchard,} 1875

Recorded only from Thetsumi trail near the Tsoyiphe stream in July 2011 and from Ezilu in March 2011 at Chizami. Some authors treat Araschnia dohertyi as a separate species. Rare. Reported to be abundant from the Naga Hills between 1,800-2,400 m (Elwes 1891) who states that its larval food plant is a nettle. Tytler (1911) states that it is fairly common post-monsoon.

121. Autumn Leaf Doleschallia bisaltide indica Moore, 1899

Recorded from the NEN compound and the Erule trail at Chizami, seen during summer season. Uncommon. Common at low elevations but scarce near Kohima (Tytler 1911).

\section{Orange Oakleaf Kallima inachus inachus Boisduval,} 1836

Recorded from the Erule riverside at Chizami between February and July. Common. Reported to be fairly common from the Naga Hills (Elwes 1891; Tytler 1911).

123. Scarce Blue Oakleaf Kallima knyvettii de Nicéville, 1886

Recorded from the Thetsumi trail at Chizami in July 2011. Rare. This species is legally protected under Schedule II of the Wildlife (Protection) Act, 1972. Reported to be "not uncommon" from the Naga Hills (Elwes 1891). Tytler (1911) reports it to be rather rare from the Naga Hills.

\section{Great Eggfly Hypolimnas bolina jacintha Drury, 1773}

Recorded from NEN compound and Erule riverside at Chizami. Uncommon. Reported to be common at low elevations from the Naga Hills (Tytler 1911).

\section{Peacock Pansy Junonia almana almana Linnaeus, 1758}

Recorded from many different locations at Chizami during the summer. Uncommon. Reported to be not uncommon from the Naga Hills (Tytler 1911).

126. Yellow Pansy Junonia hierta hierta Fabricius, 1798 Recorded only one individual at Erule River in October
2012, Chizami. Rare in the survey area. Reported to be fairly common from the low elevations of Naga Hills (Tytler 1911).

\section{Chocolate Pansy Junonia iphita iphita Cramer, 1779}

Recorded from many different locations at Chizami. Seen in both pre- and post-monsoon seasons. Very common. Reported to be very common from the Naga Hills (Tytler 1911).

\section{Lemon Pansy Junonia lemonias lemonias Linnaeus, 1758 \\ Recorded from NEN compound between January} and July. Uncommon. Reported to be very common from the low elevations of Naga Hills and not collected above 1,200 m (Tytler 1911).

\section{Blue Pansy Junonia orithya ocyale Hübner, 1816}

Recorded from many different locations at Chizami in February, July and October. Very common. Reported to be very common from the Naga Hills (Tytler 1911).

\section{Indian Blue Admiral Kaniska canace canace} Linnaeus, 1763

Recorded from many different locations at Chizami. Common. Reported to be common from the Naga Hills (Tytler 1911).

131. Spotted Jester Symbrenthia hypselis cotanda Moore, 1874

A single record from the NEN compound in August 2011. Rare. Reported to be rather common from the Naga Hills (Tytler 1911).

\section{Common Jester Symbrenthia lilaea khasiana Moore, 1874}

Recorded from the NEN compound, the Government high school area and many other different parts of Chizami through most of the year. Common. Reported to be common from the Naga Hills (Tytler 1911).

\section{Blue-tailed Jester Symbrenthia niphanda niphanda Moore, 1872}

A single record from the NEN compound in June 2013. Very rare. This species is legally protected under Schedule II of the Wildlife (Protection) Act, 1972. Reported to be rare in the Naga Hills with only three individuals being collected in two years in August and October (Tytler 1911). 
134. Painted Lady Vanessa cardui cardui Linnaeus, 1758

Recorded from different locations of Chizami during the summer season. Common. Reported to be very common from the Naga Hills (Tytler 1911).

\section{Indian Red Admiral Vanessa indica indica Herbst} 1794

Recorded from many different locations at Chizami during the pre- and post- monsoon seasons. Common. Reported to be common from the Naga Hills (Tytler 1911).

Family Nymphalidae, Subfamily Pseudergolinae 136. Constable Dichorragia nesimachus nesimachus Doyère, 1840

A single record from below the NEN compound in August 2011. Very rare in the survey area.

\section{Tabby Pseudergolis wedah wedah Kollar, 1844}

Recorded from Thetsumi and Erule trails at Chizami mostly post- monsoon from July onwards. Often seen mud-puddling. Common. Reported to be not uncommon from the Naga Hills (Tytler 1911).

\section{Popinjay Stibochiona nicea nicea Gray, 1846}

Records from the Thopfu and Tsetsumi trails at Chizami in February 2010 and July 2011. Rare in the survey area. Reported to be not uncommon in the Naga Hills (Tytler 1911).

Family Nymphalidae, Subfamily Satyrinae 139. Yellow Dryad Aemona amathusia Hewitson, 1862 Recorded from the NEN compound area at Chizami in the summer. Uncommon. This species is legally protected under Schedule II of the Wildlife (Protection) Act, 1972. Reported to be very rare in the Naga Hills (Tytler 1911).

140. Common Duffer Discophora sondaica zal Westwood, 1851

A single record from the NEN compound in May 2012. Very rare in the survey area. Reported to be common from low elevations in the Naga Hills (Tytler 1911).

141. Large Faun Faunis eumeus assama Westwood, 1858

A single record from the Tahulu trail at Chizami in September 2011. Very rare in the survey area. This species is legally protected under Schedule II of the Wildlife (Protection) Act, 1972.
142. Jungle Glory Thaumantis diores diores Doubleday, 1845

A single record from Chizami Village late evening in November 2012. Very rare in the survey area. Reported from the Naga Hills (Tytler 1911).

\section{Callerebia orixa Moore, 1872}

Recorded from the NEN compound. A few worn and poorly marked individuals were recorded and could not be identified to the species level with certainty, though it is likely that these were $C$. orixa. Rare in the survey area. Several specimens collected from the Naga Hills and reported to be common post-monsoon (Elwes 1891; Tytler 1911).

\section{Common Palmfly Elymnias hypermnestra undularis} Drury, 1773

Recorded from Erule and Kuwari at Chizami during the summer months. Common. Reported to be common in the Naga Hills (Tytler 1911).

145. Spotted Palmfly Elymnias malelas malelas Hewitson, 1863

Recorded from many different parts of Chizami's forests. Common.

146. Banded Treebrown Lethe confusa confusa Aurivillius, 1898

Recorded below the NEN compound in Mar 2013. Rare. Reported to be common from Kohima (Tytler 1911).

147. Common Treebrown Lethe rohria rohria Fabricius, 1787

Recorded from many different locations at Chizami between March and October. Common. Reported to be common from Kohima (Tytler 1911).

148. Straight-banded Treebrown Lethe verma sintica Fruhstorfer, 1911

Recorded from many different locations of Chizami forests between March and October. Common. Seen visiting animal sheds. Reported to be very common at altitudes between 1,500-2,000 $\mathrm{m}$ in the Naga Hills (Tytler 1911).

149. Angled Red Forester Lethe chandica chandica Moore, 1857

Recorded from inside the village and from the NEN compound in July 2011 and March 2013. Rare. 
150. Common Red Forester Lethe mekara mekara Moore, 1857

A single record from the NEN compound at Chizami in October 2012. Very rare in the survey area.

\section{Tailed Red Forester Lethe sinorix sinorix Hewitson,} 1863

Recorded from many different locations at Chizami sporadically throughout the year including the winter months. Common. This subspecies is legally protected under Schedule II of the Wildlife (Protection) Act, 1972. Reported from the Naga Hills (Elwes 1891; Tytler 1911).

\section{Bamboo Forester Lethe cf. kansa Moore, 1857}

Two sightings of this butterfly in the same locationjust outside NEN compound, near a clump of bamboo in January 2013. UNH ocellus in four on an even curve hence seems to be Lethe kansa in its dry season form. However, the upperside could not be seen, and hence this identification is only provisional. Rare. Reported from the Naga foothills from May to August (Tytler 1911).

153. Pale Forester Lethe latiaris latiaris Hewitson, 1863

Recorded from the NEN compound at Chizami and the forest trail below NEN compound in April 2011, October 2012 and August 2013. Rare. Reported to be not uncommon between 1,500-2,000 m, September and October (Tytler 1911).

\section{Common Woodbrown Lethe sidonis Hewitson, 1863}

Two individuals recorded from the NEN compound in the summer months. Rare in the survey area. Reported from the Naga Hills (Elwes 1891). Reported to be very common at altitudes between 1,500-2,000 $\mathrm{m}$ in the Naga Hills (Tytler 1911).

\section{Lilacfork Lethe cf. sura Doubleday, 1849}

A single unconfirmed record on the Thopfu trail at Chizami in November 2012. The butterfly was photographed sitting on the upper surface of a leaf, high up in the canopy, and its upperside could not be observed. Reported to be very common in the Naga Hills (Tytler 1911).

\section{Common Evening Brown Melanitis leda leda Linnaeus, 1758}

Recorded from different locations at Chizami in the pre- and post- monsoon seasons. Common. Reported to be fairly common in the Naga Hills (Tytler 1911).
157. Dark Evening Brown Melanitis phedima bela Moore, 1857

Recorded from the NEN compound in July 2011 and October 2012. Uncommon. Reported to be common in the Naga Hills (Tytler 1911).

\section{Great Evening Brown Melanitis zitenius zitenius} Herbst, 1796

A few records of individuals identified in hand in DSF in forest below NEN compound in Oct 2012. Rare. This species is legally protected under Schedule II of the Wildlife (Protection) Act, 1972.

159. White-line Bushbrown Heteropsis malsara Moore, 1857

Recorded from many different locations of the forested areas at Chizami and at the NEN compound in July 2011 and October 2012. This species was earlier considered to be part of the Genus Mycalesis but recent phylogenetic studies have re-classified them in Genus Heteropsis (Kodandaramaiah et al. 2010). Common. Only a single record from the Naga Hills (Tytler 1911).

160. Lilacine Bushbrown Mycalesis francisca sanatana Moore, 1857

Recorded from many different locations at Chizami in July and October. Common. Seen mud-puddling at the riverside occasionally, but seen mostly on the footpaths leading to the fields and inside the bushes. Reported from the Naga Hills (Elwes 1891, Tytler 1911).

161. Lepcha Bushbrown Mycalesis lepcha kohimensis Tytler, 1914

Recorded from many different locations of the forested areas at Chizami. Common. Dry season form reported in March and April and wet season form in August and October from Kohima (Tytler 1911; Tytler 1914).

\section{White-edged Bushbrown Mycalesis mestra sadona Tytler, 1939}

Recorded from two locations at Chizami-the NEN compound and at Awu in October 2012. Rare in the survey area. This species is legally protected under Schedule II of the Wildlife (Protection) Act, 1972.

163. Veined Labyrinth Neope pulaha pulaha Moore, 1857

Recorded from the NEN compound, near the kitchen. Two individuals recorded at the same location in September 2011 and May 2013. Rare. Reported from 
the Naga Hills (Elwes 1891).

164. Tiger Brown Orinoma damaris damaris Gray, 1846

Two individuals recorded from different locations at Chizami in October 2012. Rare. Reported at 1,500m in September and October and reported to be not common in the Naga Hills (Tytler 1911).

165. Common Five-ring Ypthima baldus baldus Fabricius, 1775

Recorded from all locations at Chizami mostly between March and July. Common. Reported to be common from the Naga Hills (Tytler 1911).

166. Newar Three-ring Ypthima cf. newara newara Moore, 1874

Recorded from all locations at Chizami area in July and October. Common. All the individuals recorded had a larger sub-apical ocellus UNH and lacked UNF/H submarginal dark lines, than individuals recorded elsewhere in northeastern India by SS. It is difficult to separate $Y$. newara and $Y$. confusa without examining male genitalia hence only provisionally identified.

167. Himalayan Five-ring Ypthima sakra sakra Moore, 1857

Recorded from all locations at Chizami in the preand post-monsoon seasons. Common. Reported from the Naga Hills (Elwes 1891; Tytler 1911).

\section{Ypthima spp.}

At least two separate individuals, which did not match any of the large-sized fiverings: Ypthima savara, Ypthima methora, Ypthima dohertyi or Ypthima persimilis. Both these individuals had wingspans $>45 \mathrm{~mm}$, were heavily striated on both wings UNF/H. UNF: in addition to large sub-apical doubled-pupilled ocellus, and additional ocellus in two. UNH: with five mostly equal-sized ocelli, with pupils. Tornal ocelli merged. Seen at Chizami in the forested areas in Oct 2012.

\section{Family Papilionidae, Subfamily Papilioninae}

169. Green Dragontail Lamproptera meges indistincta Tytler, 1912

Recorded from all locations at Chizami. Mostly seen during the summer between March and July. Often seen mud-puddling. Common. Reported to be not uncommon between 1,200-1,500 m from April to October (Tytler 1912).
170. Tailed Jay Graphium agamemnon agamemnon Linnaeus, 1758

Recorded by Kewekhrozo Thopi on the village approach road leading to Chizami Village near NEN area and by SS in October 2012. Rare in the survey area. Reported to be common from the Naga Hills (Tytler 1912).

171. Glassy Bluebottle Graphium cloanthus cloanthus Westwood, 1841

Recorded from the NEN compound. Often seen visiting flowers during the summer. Rare. Reported to be not common from the Naga Hills (Tytler 1912).

\section{Common Bluebottle Graphium sarpedon sarpedon Linnaeus, 1758}

Recorded from all locations at Chizami. Mostly seen visiting flowers and mud-puddling on the riverbank. Uncommon. Reported to be common from the Naga Hills (Tytler 1912).

\section{Common Mime Papilio clytia clytia Linnaeus, 1758}

Form dissimillis recorded from the Erule riverbank at Chizami. Seen mud-puddling. Rare. Form dissimilis reported to be common from the Naga Hills (Tytler 1912).

174. Lesser Mime Papilio epycides epycides Hewitson, 1862

A single record from the NEN compound in April 2014. Very rare.

175. Red Helen Papilio helenus helenus Linnaeus, 1758

Recorded from all locations at Chizami between March and October. Mostly seen visiting flowers. Locally common. Reported to be common from the Naga Hills (Tytler 1912).

176. Yellow Helen Papilio nephelus chaon Westwood, 1845

Recorded from the Erule riverbank at Chizami in August 2013. Rare. Reported at low elevations from the Naga Hills (Tytler 1912).

\section{Great Mormon Papilio memnon agenor Linnaeus, 1758}

Recorded from the Erule riverbank and other forested areas at Chizami in July and October. Seen mudpuddling, Forms agenor and distantianus seen. Rare. Reported "sparingly" from the Naga Hills (Tytler 1912). 
178. Common Mormon Papilio polytes romulus Cramer, 1775

Recorded from the Awelu trail at Chizami. Rare in the survey area. Reported to be common from the Naga Hills (Tytler 1912).

179. Redbreast Papilio alcmenor alcmenor Felder \& Felder, 1864

Recorded from the Erule riverbank at Chizami. Seen mud-puddling. Rare. Reported from the Naga Hills (Tytler 1912).

180. Spangle Papilio protenor euprotenor Fruhstorfer, 1908

Recorded from all locations at Chizami. Seen mostly in the months of March and July. Twenty-five individuals were recorded in March alone. Very common. Reported to be common from the Naga Hills (Tytler 1912).

181. Lime Butterfly Papilio demoleus demoleus Linnaeus, 1758

Recorded from all locations at Chizami mostly during the summer season. Common. Reported from the Naga Hills (Tytler 1912).

182. Blue Peacock Papilo arcturus arcturus Westwood, 1842

Recorded from the NEN compound in October 2012. Rare. Reported to be not uncommon from the Naga Hills (Tytler 1912).

183. Common Peacock Papilio bianor ganesa Doubleday, 1842

Recorded from numerous locations at Chizami. Common. Reported rather commonly from the Naga Hills (Tytler 1912).

184. Paris Peacock Papilio paris paris Linnaeus, 1758 Recorded from all locations at Chizami. Seen mostly visiting flowers in gardens. Common. Reported to be very common from the Naga Hills (Tytler 1912).

185. Common Batwing Atrophaneura varuna astorion Westwood, 1842

Recorded from the NEN compound. Rare. Collected "sparingly" in the Naga Hills (Tytler 1912).

186. Common Windmill Byasa polyeuctes polyeuctes Doubleday, 1842

Recorded from many different locations at Chizami. Common. Collected "commonly" from the Naga Hills
(Tytler 1912).

187. Birdwing spp. Troides spp.

A birdwing seen in flight by SS though species level identification was not possible.

Family Pieridae, Subfamily Coliadinae

188. Three-spot Grass Yellow Eurema blanda silhetana Wallace, 1867

Recorded from all locations at Chizami. Common. Reported to be not common from August to September at Kohima (Tytler 1912).

189. Small Grass Yellow Eurema brigitta rubella Wallace, 1867

Recorded from all locations at Chizami. Common. Reported to be not very common from the Naga Hills (Tytler 1912).

190. Common Grass Yellow Eurema hecabe hecabe Linnaeus, 1758

Recorded from all locations at Chizami. Common. Reported to be very common from the Naga Hills (Tytler 1912).

191. Spotless Grass Yellow Eurema laeta sikkima Moore, 1906

Recorded from many different locations at Chizami. Common. Reported to be rather common from Kohima (Tytler 1912).

Family Pieridae, Subfamily Pierinae

192. Common Albatross Appias albina darada Felder \& Felder, 1865

Recorded from the NEN compound. Male and female seen. Rare in the survey area. This subspecies is legally protected under Schedule II of the Wildlife (Protection) Act, 1972. Reported to be rare from the Naga Hills (Tytler 1912).

193. Orange Albatross Appias galba Wallace, 1867

Two individuals recorded from Chizami Village. Seen mud-puddling. Rare. This subspecies is legally protected under Schedule IV of the Wildlife (Protection) Act, 1972. Reported to be not uncommon from the Naga Hills (Tytler 1912).

194. Spot Puffin Appias lalage lalage Doubleday, 1842 Recorded from many different locations at Chizami. Common. Reported to be rather common from the Naga Hills (Tytler 1912). 
195. Lesser Gull Cepora nadina nadina Lucas, 1852

Recorded from two locations-the NEN compound and Erule riverbank at Chizami. Rare in the survey area. A few individuals recorded from the Naga Hills (Tytler 1912).

196. Common Emigrant Catopsilia pomona pomona Fabricius, 1775

Recorded from the NEN compound. Uncommon. Reported to be not uncommon from the Naga Hills (Tytler 1912).

197. Mottled Emigrant Catopsilia pyranthe pyranthe Linnaeus, 1758

Recorded from the NEN compound. Uncommon.

198. Red-breast Jezebel Delias acalis pyramus Wallace, 1867

Recorded from the NEN compound and the Erule riverbank at Chizami in October 2012. Rare.

199. Hill Jezebel Delias belladonna lugens Jordan, 1925

Recorded from many different parts at Chizami. Common. Recorded as common between 1,200-2,100 $m$ in August and September in the Naga Hills (Tytler 1912).

200. Red-spot Jezebel Delias descombesi descombesi Boisduval, 1836

A single record from Chizami Village in November 2012. Very rare. A few individuals reported from the Naga Hills (Tytler 1912).

201. Red-base Jezebel Delias pasithoe pasithoe Linnaeus, 1767

Recorded from the NEN compound and the Erule riverbank at Chizami during summer. Rare.

\section{Great Orange-tip Hebomoia glaucippe glaucippe Linnaeus, 1758}

Recorded from many different locations of Chizami. Common. Reported to be common from low elevations up to $600 \mathrm{~m}$ in the Naga Hills (Tytler 1912).

203. Yellow Orange-tip Ixias pyrene familiaris Butler, 1874

Recorded from many different locations at Chizami between March and October. Common. Reported to be common from the Naga Hills (Tytler 1912).
204. Pale Wanderer Pareronia avatar Moore, 1857

Recorded from different locations of Chizami. Common. A few individuals reported from the Naga Hills (Tytler 1912).

205. Large Cabbage White Pieris brassicae nepalensis Doubleday, 1846

Recorded from all locations at Chizami through most of the year. Very common. Reported to be very scarce from the Naga Hills (Tytler 1912).

206. Indian Cabbage White Pieris canidia indica Evans, 1926

Recorded from all locations at Chizami through most of the year. Very common. Reported to be abundant throughout the year from the Naga Hills (Tytler 1912).

\section{Bath White Pontia daplidice moorei Röber, 1907}

Recorded from many different parts of Chizami. Common. This species has extended its range eastwards in recent times from the western and central Himalaya to many locations in eastern Himalaya including Assam, Arunachal Pradesh, Nagaland and Manipur (Naro \& Sondhi 2013; Singh \& Gogoi 2013).

208. Green-veined White Pieris melete ajaka Moore, 1865

Recorded from all locations at Chizami through most of the year. Very common. Reported to be rather uncommon from the Naga Hills (Tytler 1912).

209. Spotted Sawtooth Prioneris thestylis thestylis Doubleday, 1842

Recorded from many different parts at Chizami. Female recorded feeding on flower nectar in July 2011 in the NEN office complex. Males common, females rare. Reported to be common from the Naga Hills (Tytler 1912)

Family Riodinidae, Subfamily Nemeobiinae 210. Dark Judy Abisara fylla Westwood, 1851

Recorded from all locations at Chizami. Seen throughout the year. Very common. Reported to be abundant and common from the Naga Hills (Elwes 1891; Tytler 1911).

211. Striped Punch Dodona adonira adonira Hewitson, 1865

A single record from Thetsumi roadside near the stream in February 2013. Rare. Reported to be "not common" from the Naga Hills (Elwes 1891; Tytler 1911). 
212. Punchinello Zemeros flegyas fleygas Cramer, 1780

Recorded from all locations at Chizami. Seen throughout the year. Very common. Reported to be very common from the Naga Hills (Tytler 1911).

\section{REFERENCES}

Bingham, C.T. (1905-07). The Fauna of British India including Ceylone and Burma: Butterflies. Vols. I-II. Taylor and Francis Ltd., London.

Corbet, A.S. \& H.M. Pendlebury (1992). The Butterflies of the Malay Peninsula. 4th Edition revised by J.N. Eliot. Malayan Nature Society, Kuala Lumpur, 595pp.

de Jong, R. (1983). Revision of the oriental Genus Matapa Moore (Lepidoptera: Hesperiidae) with discussion of its phylogeny and geographic history. Zoologische Mededelingen 57: 21.

de Nicéville, C.L.A. (1900). On new and little-known Lepidoptera from the Oriental Region. Journal of Bombay Natural History Society 13(1): 157-175.

Eliot, J.N. (1969). An Analysis of the Eurasian and Australian Neptini (Lepidoptera: Nymphalidae). Bulletin of the British Museum (Natural History) Entomology. Supplement 15.

Elwes, H.J. (1891). On butterflies collected by Mr. W. Doherty in the Naga and Karen Hills and in Perak. Proceedings of the Zoological Society of London 1891: 249-289.

Elwes, H.J. (1892). On butterflies collected by Mr. W. Doherty in the Naga and Karen Hills and in Perak. Proceedings of the Zoological Society of London 1892: 617-664.

Evans, W.H. (1932). The Identification of Indian Butterflies. 2nd Revised Edition. Bombay Natural History Society, Bombay, $x+454 p p+32 p l$.

Evans, W.H. (1949). A catalogue of the Hesperiidae from Europe, Asia and Australia in the British Museum (Natural History). British Museum (Natural History), London, 502pp.

Evans, W.H. (1957). A revision of the Arhopala group of Oriental Lycaenidae (Lepidoptera: Rhopalocera). Bulletin of the British Museum (Natural History), London Entomology Volume 5: 85-141.

Haribal, M. (1992). The Butterflies of The Sikkim Himalaya and Their Natural History. Sikkim Nature Conservation Foundation, Gangtok, 217pp.

Huang, H. \& Y.P. Xue (2004). The Chinese Pseudocoladenia skippers. Neue Entomologische Nachrichten 57: 161-170.

Kehimkar, I. (2008). The Book of the Indian Butterflies. Bombay Natura History Society and Oxford University Press, Oxford, xvi+497pp.

Kinyon, S. (2004). Illustrated Checklist for the Butterflies of Myanmar. Smithsonian Institution, 197pp.

Kodandaramaiah, U., D.C. Lees, C.J. Müller, E. Torres, K.P. Karanth \& N. Wahlberg (2010). Phylogenetics and biogeography of a spectacular Old World radiation of butterflies: the subtribe Mycalesina (Lepidoptera: Nymphalidae: Satyrini). BMC Evolutionary Biology 10: 172

Kunte, K. (2000). Butterflies of Peninsular India. Universities Press (Hyderabad) and Indian Academy of Sciences (Bangalore), 254pp.

Marshall, G.F.L. \& L. de Nicéville (1882). The Butterflies of India, Burmah and Ceylon. Vol. I. The Calcutta Central Press Co., Calcutta, 398pp

Marshall, G.F.L. \& L. de Nicéville (1886). The Butterflies of India, Burmah and Ceylon. Vol. II.The Calcutta Central Press Co., Calcutta, 370pp.

Marshall, G.F.L. \& L. de Nicéville (1890). The Butterflies of India, Burmah and Ceylon. Vol. III. The Calcutta Central Press Co., Calcutta, $552 \mathrm{pp}$
Naro, T. (2012). Sighting of Aglais cashmirensis aesis Fruhstorfer, 1912 (Nymphalidae) from Nagaland, India. Journal of Threatened Taxa 4(4): 2534-2535; http://dx.doi.org/10.11609/JoTT.o3019.2534-5

Naro, T. \& S. Sondhi (2013). Sightings of Bath White Pontia daplidice moorei Röber, 1907 (Lepidoptera: Pieridae: Pierinae: Pierini) from Arunachal Pradesh and Nagaland, India. Journal of Threatened Taxa 5(7): 4122-4124; http://dx.doi.org/10.11609/JoTT.03308.4122-4

Singh, A.P. (2011). Butterflies of India. Om Books International, 183pp.

Singh, I.J. \& M.J. Gogoi (2013). A new range record for the Bath White butterfly Pontia daplidice for north-east India. Bionotes 15(2): 59.

Smith, C. (1993). Illustrated Checklist of Nepal's Butterflies. T.C. Majupuria (Ed.). Rohit Kumar, Gwalior. M.P., India, 127pp.

Smith, C. (1994). Butterflies of Nepal. Revised Edition, Tecpress Service L.P., Bangkok, Thailand, 368pp.

Sondhi, S. \& K. Kunte (2014). Butterflies and Moths of Pakke Tiger Reserve. Titli Trust (Dehradun) and Indian Foundation for Butterflies (Bengaluru), vi+202pp.

Sondhi, S., K. Kunte, G. Agavekar, R. Lovalekar \& K. Tokekar (2013). Butterflies of the Garo Hills. Samrakshan Trust (New Delhi), Titli Trust (Dehradun), and Indian Foundation for Butterflies (Bengaluru), xvi+200pp.

Swinhoe, C. (1912-13). Lepidoptera Indica. Vol. X. Rhopalocera. Family Hesperiidae. Reeve \& Co, London, 361pp+78pl.

Talbot, G. (1939). The Fauna of British India, including Ceylone and Burma: Butterflies. Vol. 1. Taylor and Francis, London, $600 \mathrm{pp}+3 \mathrm{pl}$

Talbot, G. (1947). The Fauna of British India, including Ceylone and Burma: Butterflies. Vol. 2. Taylor and Francis, London, 506pp $+2 \mathrm{pl}$.

Tytler, H.C. (1911). Notes on butterflies from the Naga Hills - Part II. Journal of Bombay Natural History Society 21: 588-606.

Tytler, H.C. (1912). Notes on butterflies from the Naga Hills - Part I. Journal of Bombay Natural History Society 21: 48-65.

Tytler, H.C. (1914). Notes on some new and interesting butterflies from Manipur and the Naga Hills. Part - I. Journal of Bombay Natural History Society 23: 216-229.

Tytler, H.C. (1915a). Notes on some new and interesting butterflies from Manipur and the Naga Hills. Part - II. Journal of Bombay Natural History Society 23: 502-515.

Tytler, H.C. (1915b). Notes on some new and interesting butterflies from Manipur and the Naga Hills. Part - III. Journal of Bombay Natural History Society 24: 119-155.

Tytler, H.C. (1940). Notes on Some New and Interesting Butterflies chiefly from Burma. Part - 2. Journal of Bombay Natural History Society 42: 109-123.

Varshney, R.K. (2008a). First Bibliography of the Butterflies of Indian Region. Bionotes 10(2): 43-46.

Varshney, R.K. (2008b). First Bibliography of the Butterflies of Indian Region. Bionotes 10(3): 81-86.

Varshney, R.K. (2008c). First Bibliography of the Butterflies of Indian Region. Bionotes 10(4): 143-146.

Varshney, R.K. (2009a). First Bibliography of the Butterflies of Indian Region. Bionotes 11(1): 30-33.

Varshney, R.K. (2009b). First Bibliography of the Butterflies of Indian Region. Bionotes 11(2): 47-50.

Varshney, R.K. (2009c). First Bibliography of the Butterflies of Indian Region. Bionotes 11(3): 86-89.

Varshney, R.K. (2009d). First Bibliography of the Butterflies of Indian Region. Bionotes 11(4): 119-121.

Wynter-Blyth, M.A. (1957). Butterflies of The Indian Region. Bombay Natural History Society, Bombay, $x x+523 p p+72 p l$. 


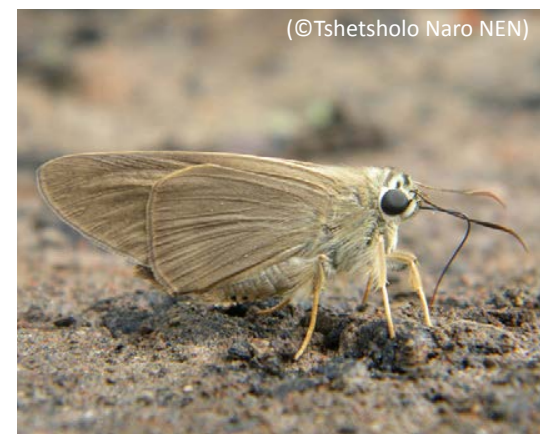

Image 1. Brown Awl Badamia exclamationis

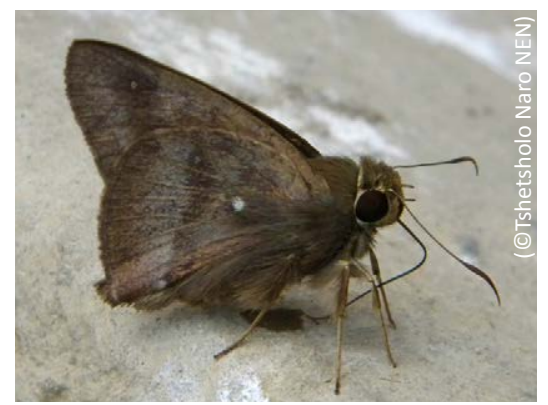

Image 4. State Awl Hasora anura anura

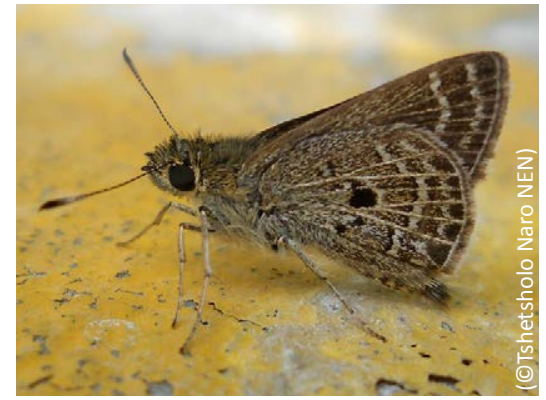

Image 7. Veined Scrub Hopper Aeromachus stigmata obsoleta

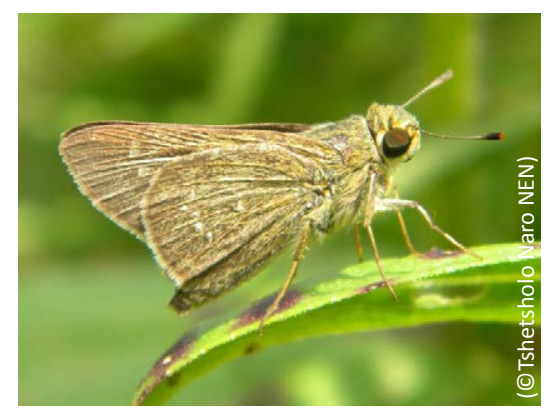

Image 10. Straight Swift Parnara cf. guttatus

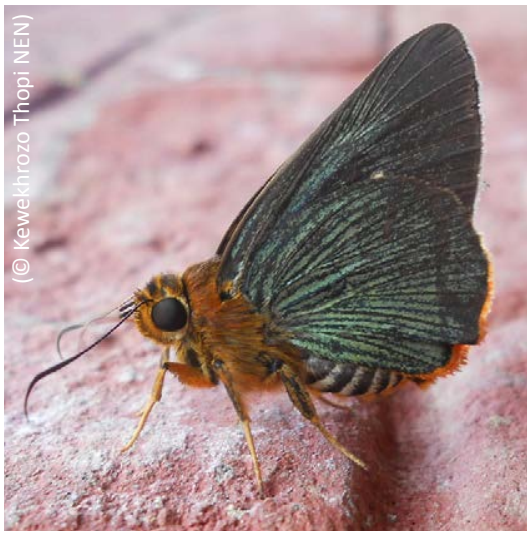

Image 2. Green Awlet Bibasis vasutana

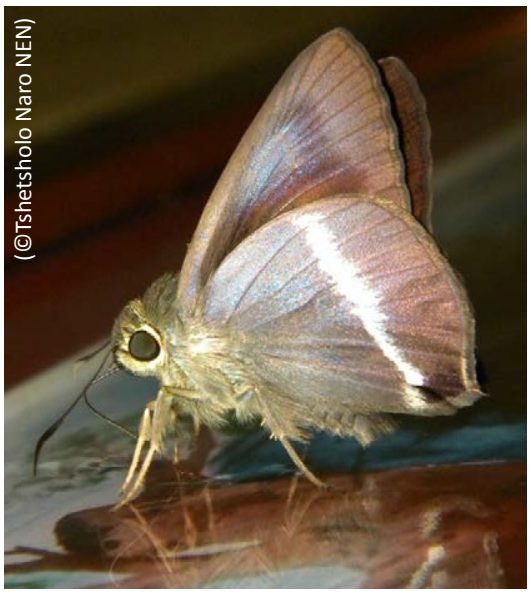

Image 5. White-banded Awl Hasora taminatus bhavara

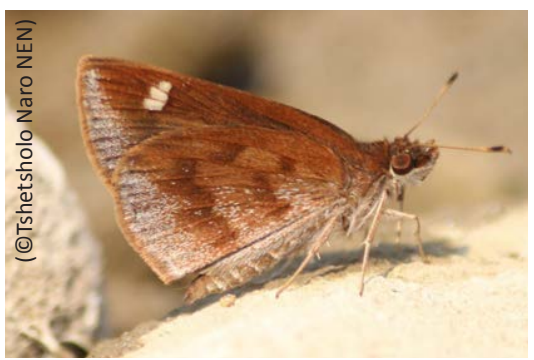

Image 8. Forest Hopper Astictopterus jama olivascens

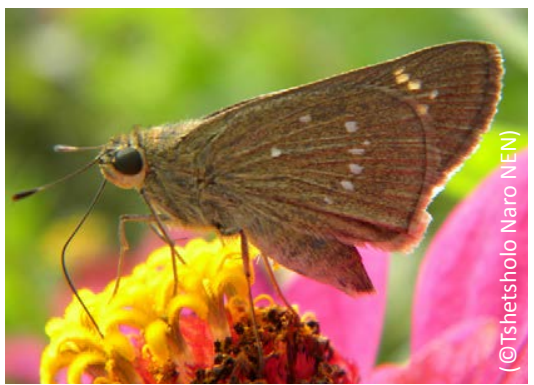

Image 11. Small Banded Swift Pelopidas mathias mathias

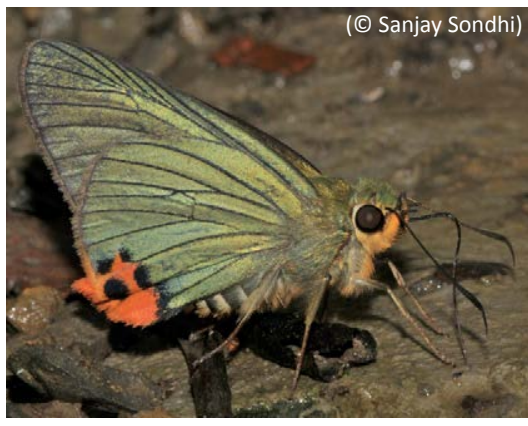

Image 3. Indian Awlking Choaspes benjaminii japonica

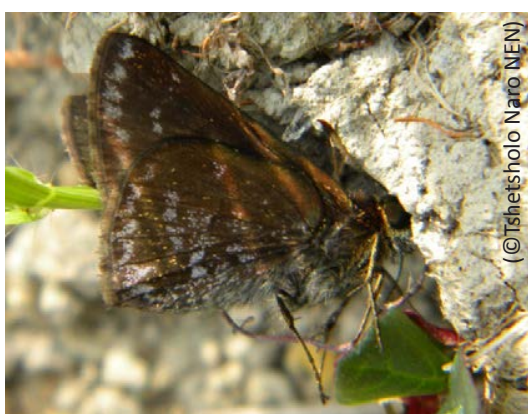

Image 6. Blue-spotted Scrub Hopper

Aeromachus kal

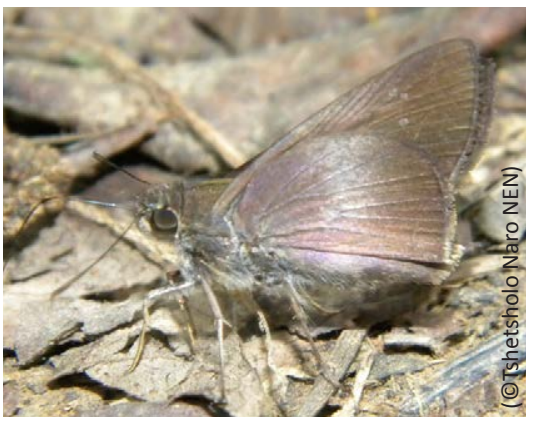

Image 9. Purple Swift Caltoris tulsi

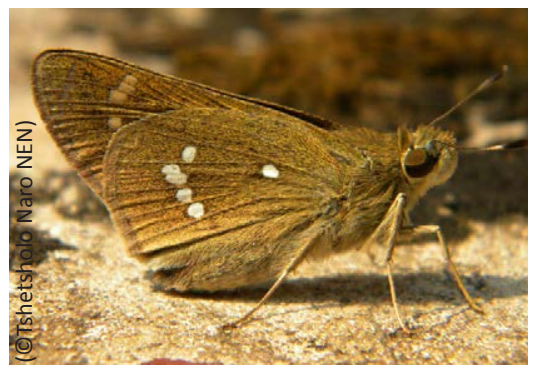

Image 12. Large Banded Swift Pelopidas sinensis 


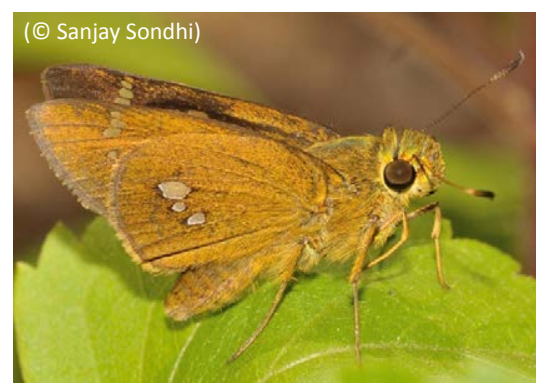

Image 13. Yellow Spot Swift Polytremis eltola eltola

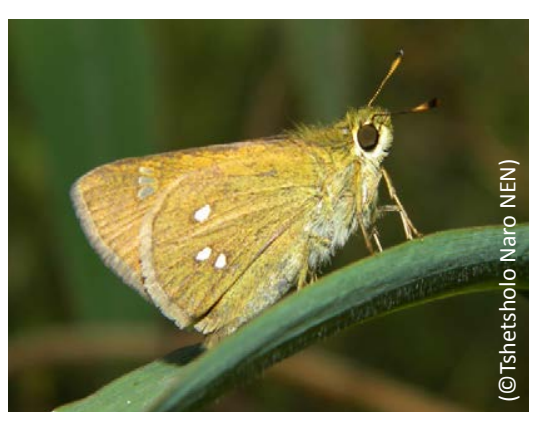

Image 15. Assam Darter Ochlodes siva siva

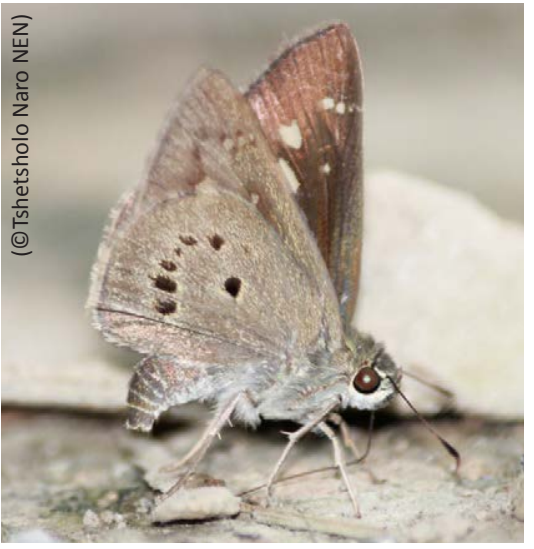

Image 18. Indian Palm Bob Suastus gremius gremius

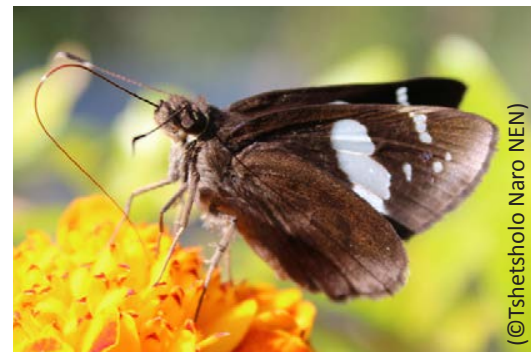

Image 21. Restricted Demon Notocrypta curvifascia curvifascia

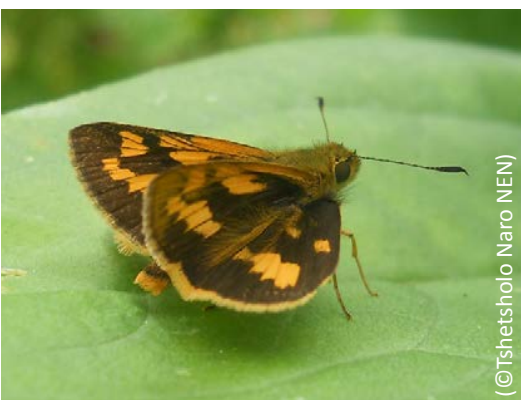

Image 14. Dart spp. Potanthus spp.

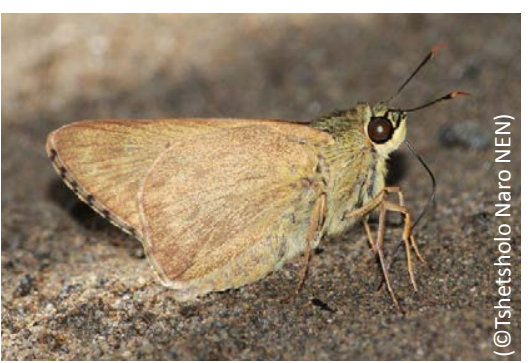

Image 16. Light Straw Ace Pithauria stramineipennis stramineipennis

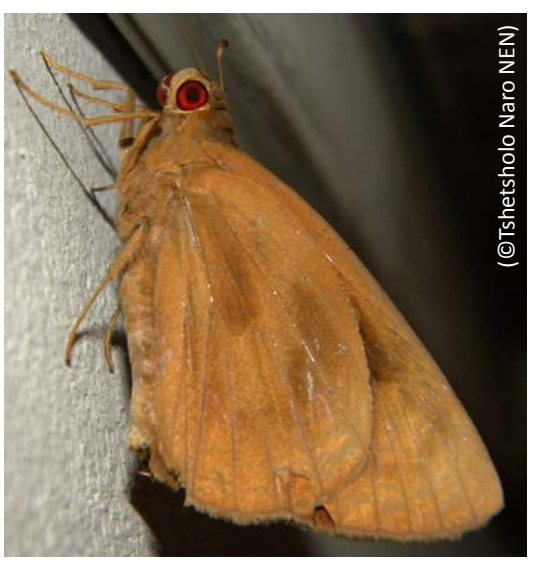

Image 19. Sikkim Palm Redeye Erionota torus

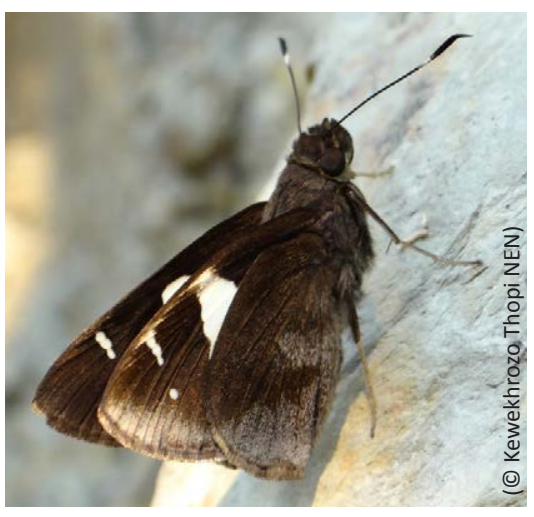

Image 22. Spotted Demon Notocrypta feisthamelii alysos

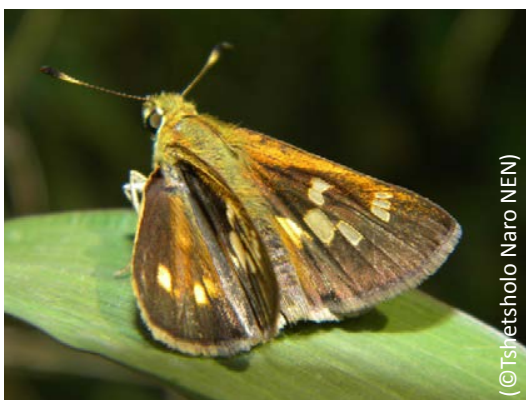

Image 15. Assam Darter Ochlodes siva siva

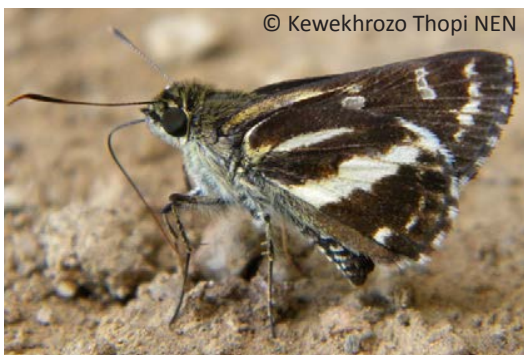

Image 17. Tufted Ace Sebastonyma dolopia
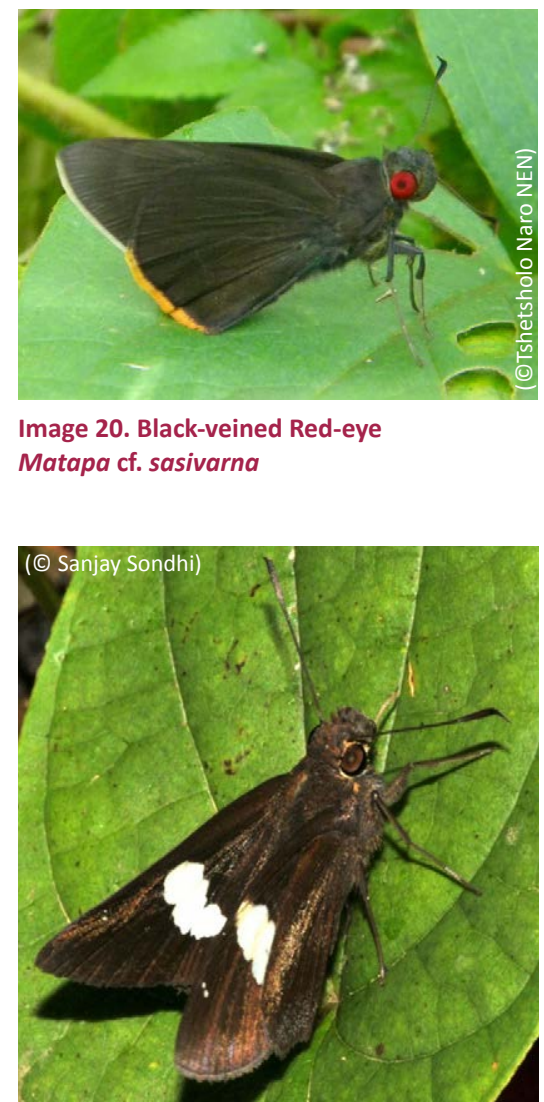

Image 23. Common Banded Demon Notocrypta paralysos asawa 


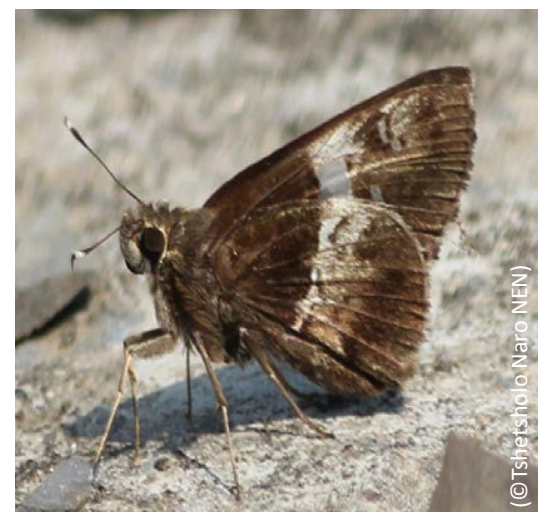

Image 24. Tree Flitter Hyarotis adrastus praba

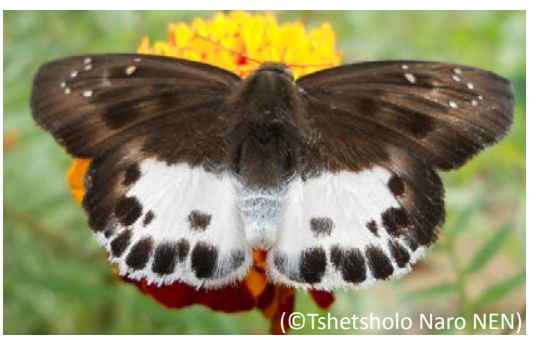

Image 27. Spotted Snow Flat Tagiades menaka menaka

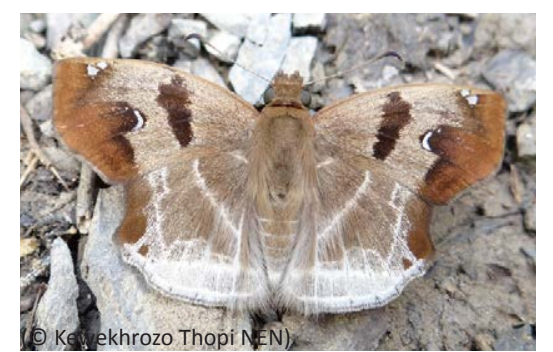

Image 30. Chestnut Angle Odontoptilum angulata angulata

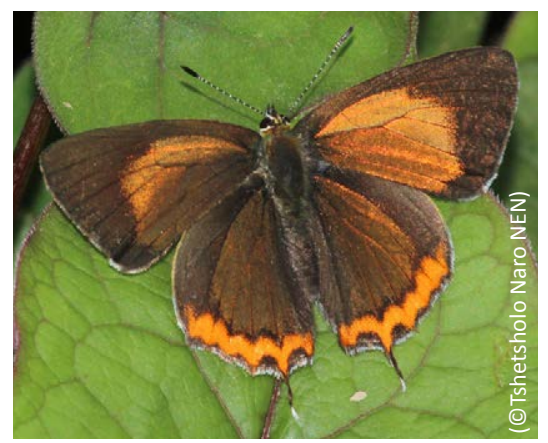

Image 32. Golden Sapphire Heliophorus brahma brahma

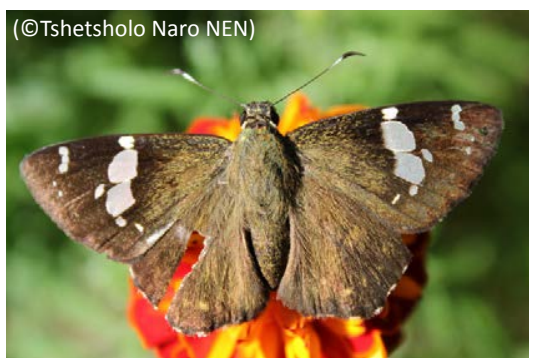

Image 25. Common Spotted Flat

Celaenorrhinus leucocera

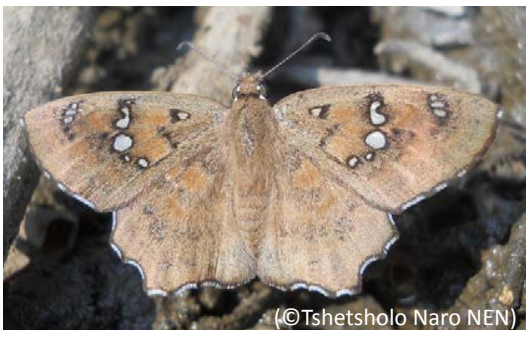

Image 28. Spotted Angle Caprona agama agama

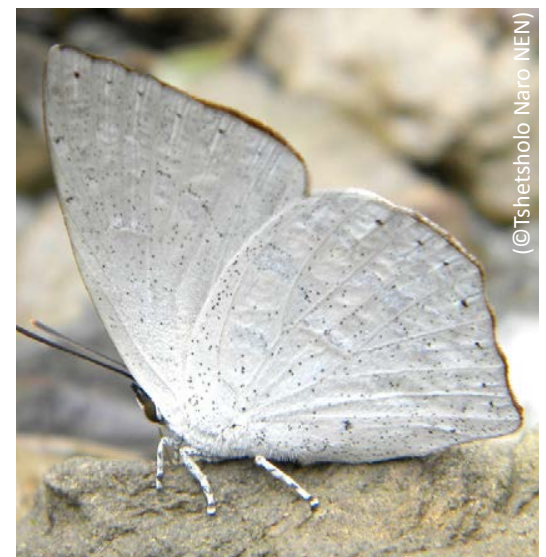

Image 31. Bright Sunbeam Curetis bulis bulis

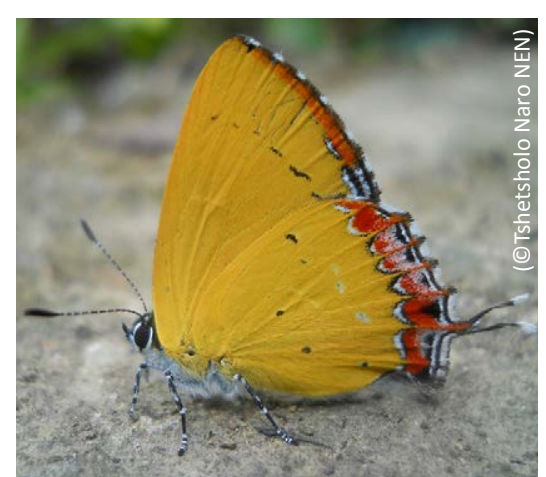

Image 33. Naga Sapphire Heliophorus

kohimensis kohimensis

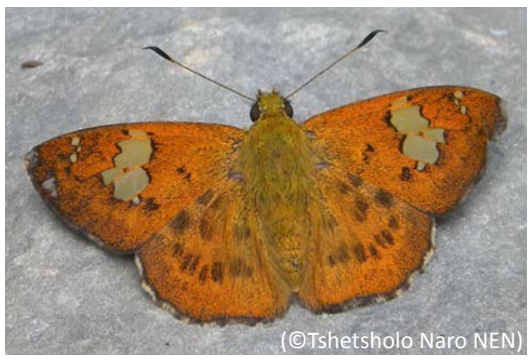

Image 26. Ruddy Pied Flat

Pseudocoladenia cf. fatua

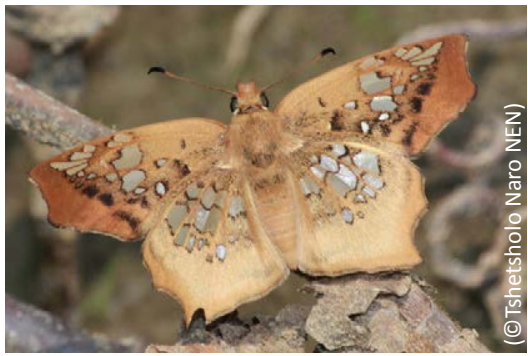

Image 29. Tawny Angle Ctenoptilum vasava vasava

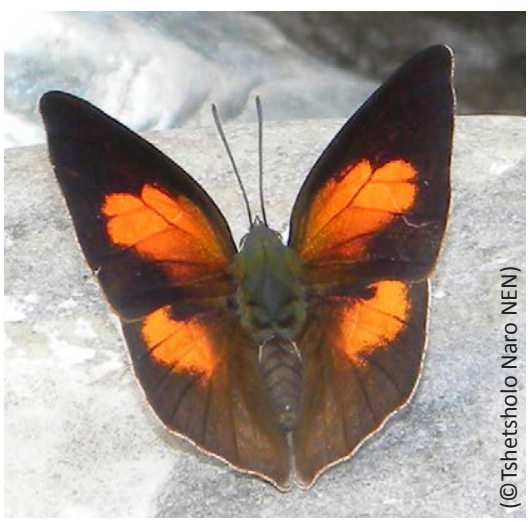

Image 31. Bright Sunbeam Curetis bulis bulis

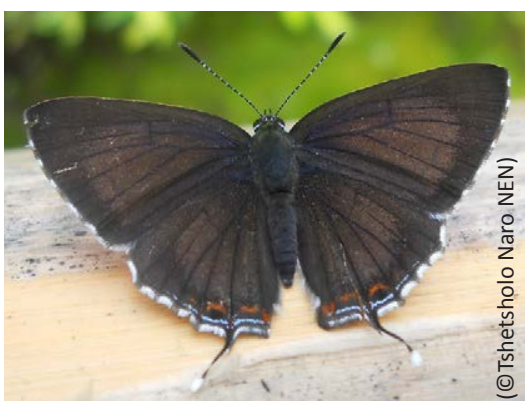

Image 33. Naga Sapphire Heliophorus kohimensis kohimensis 


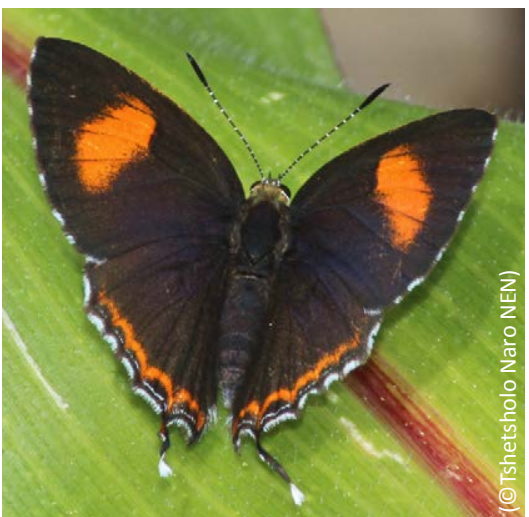

Image 33. Naga Sapphire female

Heliophorus kohimensis kohimensis

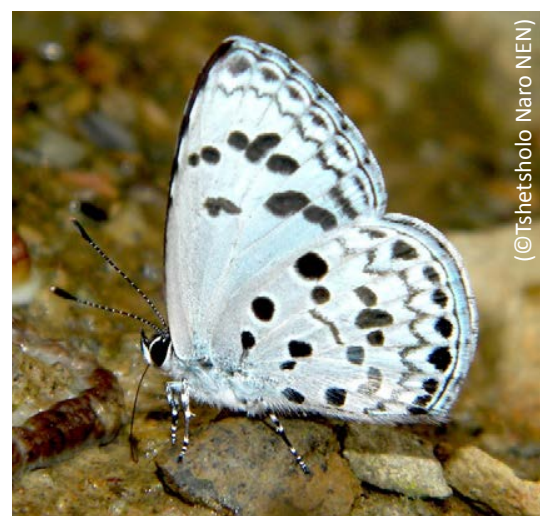

Image 36. Common Hedge Blue Acytolepis puspa gisca

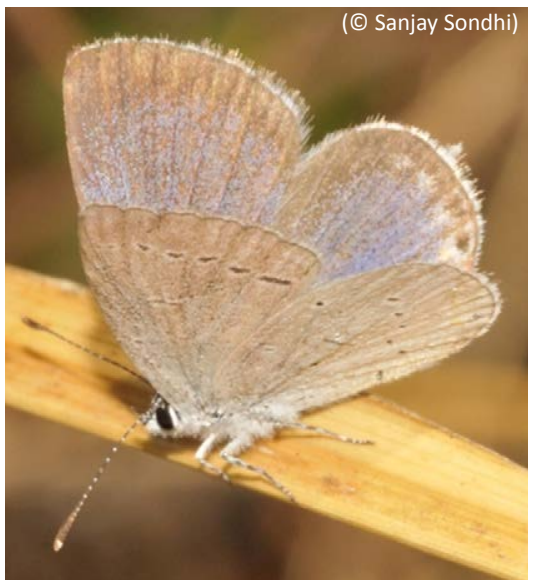

Image 39. Hedge Cupid Bothrinia chennellii

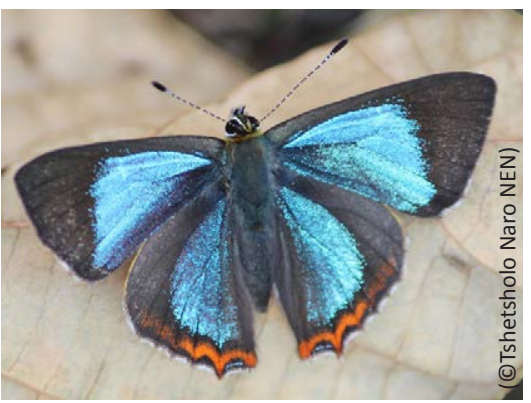

Image 34. Green Sapphire Heliophorus moorei tytleri

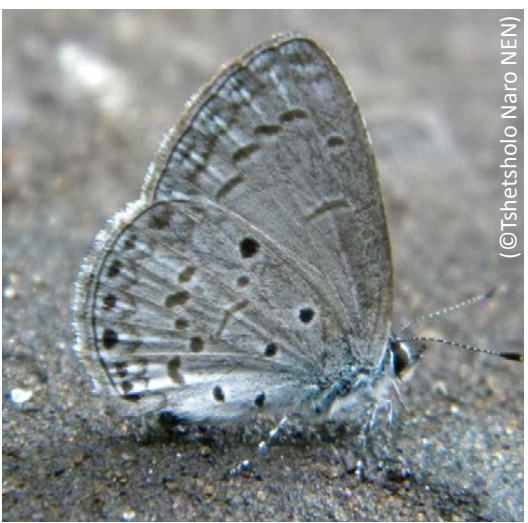

Image 37. Plain Hedge Blue Celastrina lavendularis limbata

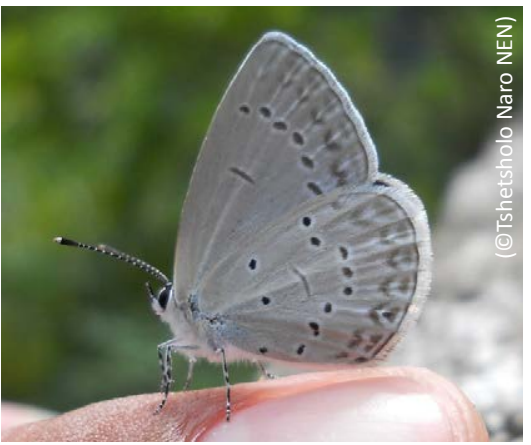

Image 39. Bothrinia chennellii Hedge Cupid

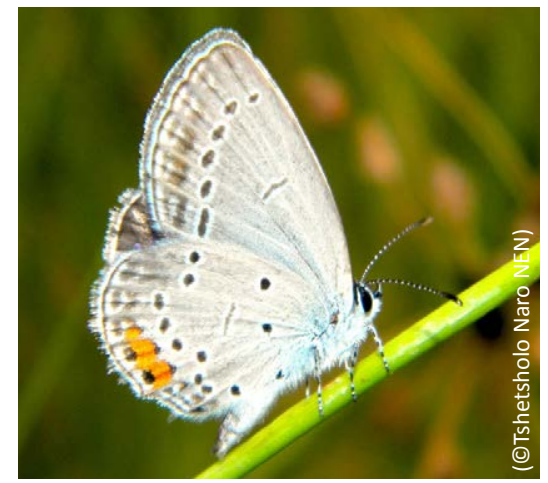

Image 40. Chapman's Cupid Everes argiades diporides

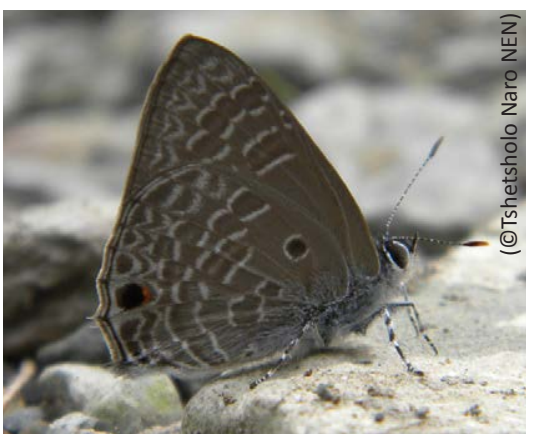

Image 35. Pointed Ciliate Blue Anthene lycaenina lycambes

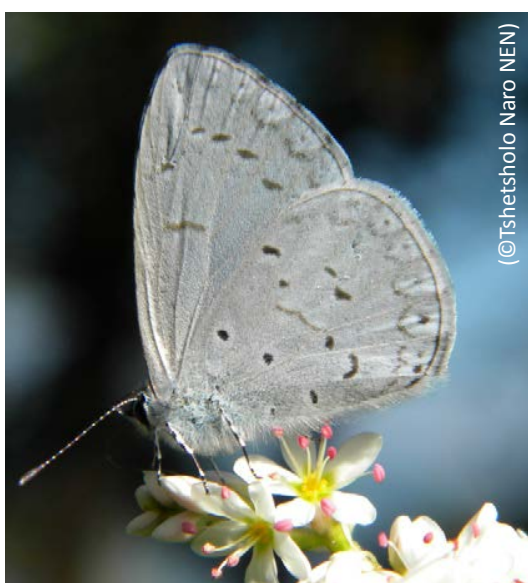

Image 38. Pale Hedge Blue Udara dilecta dilecta

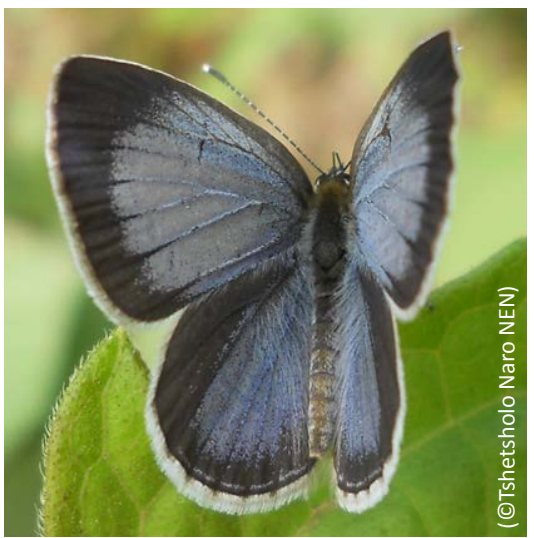

Image 39. Hedge Cupid Bothrinia chennellii 


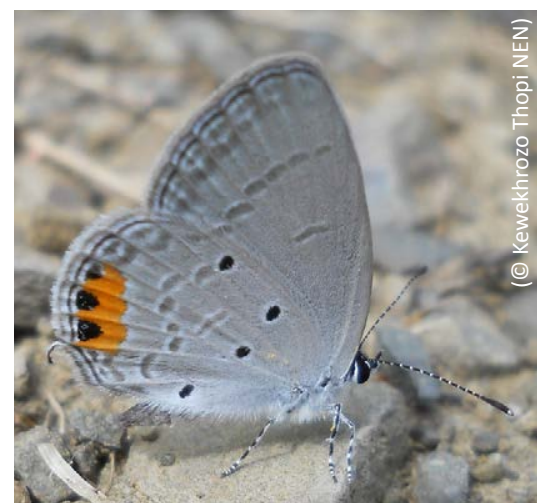

Image 41. Indian Cupid Everes lacturnus assamica

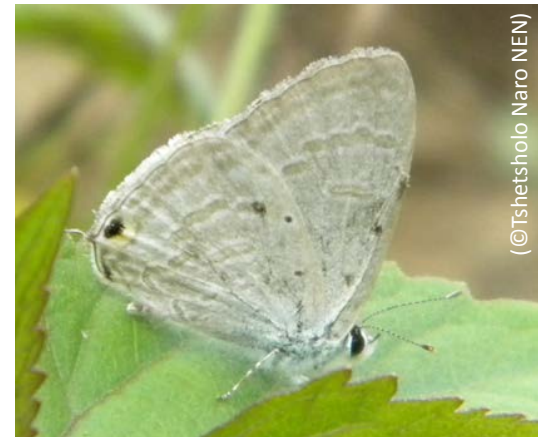

Image 43. Forget-me-not

Catochrysops strabo strabo

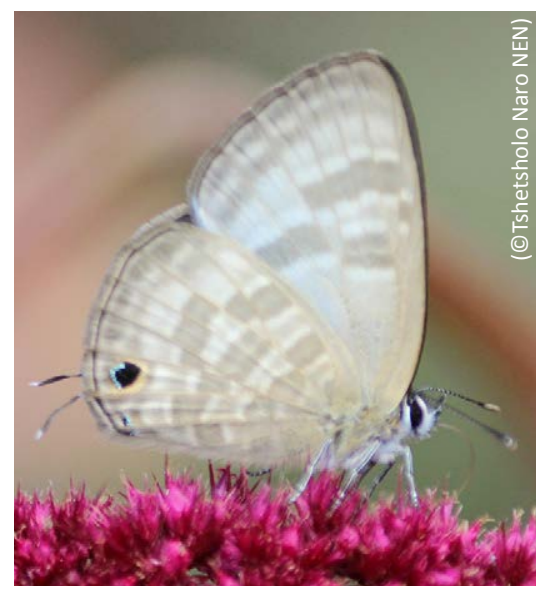

Image 46. Cerulean Jamides sp.

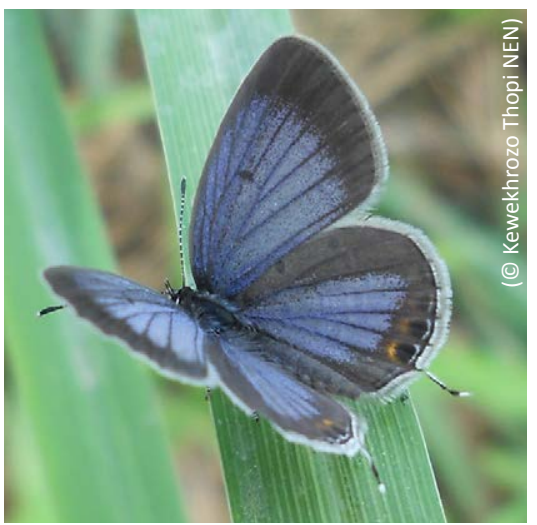

Image 41. Indian Cupid Everes lacturnus assamica

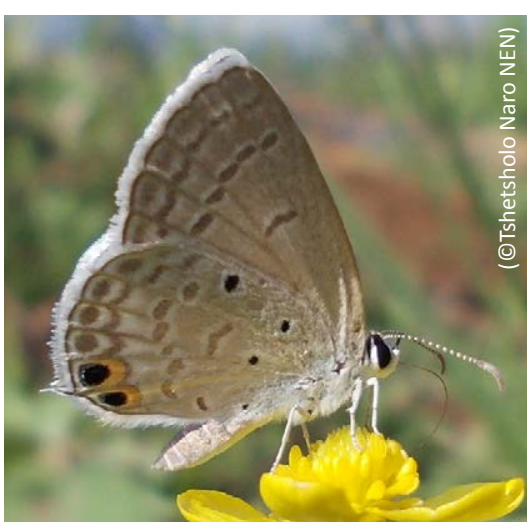

Image 44. Gram Blue female Euchrysops cnejus cnejus

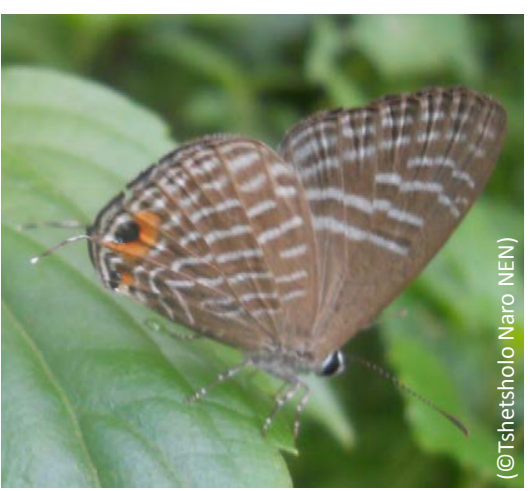

Image 47. Glistening Cerulean Jamides elpis pseudoelpis

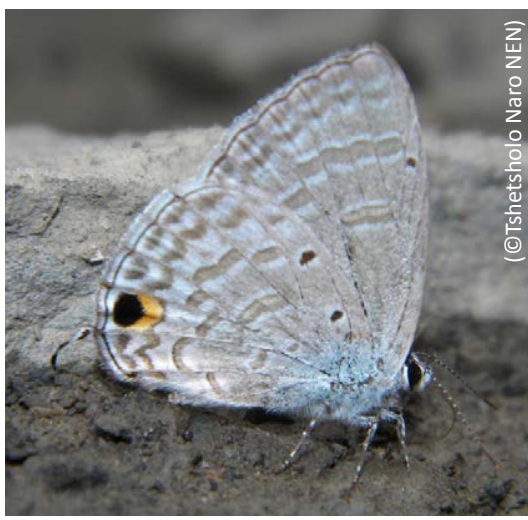

Image 42. Silver Forget-me-not Catochrysops panormus exiguus

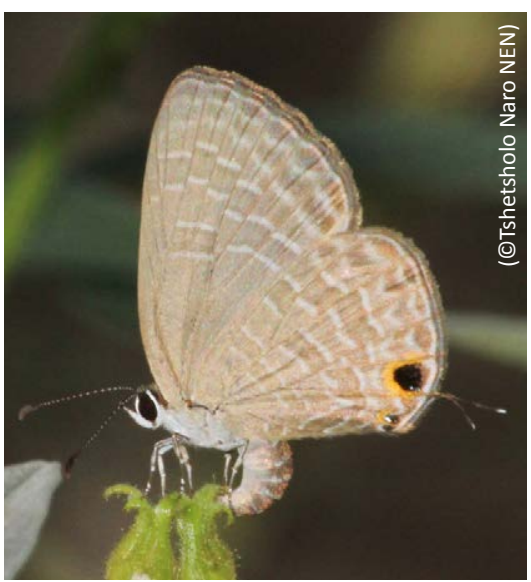

Image 45. Dark Cerulean Jamides bochus bochus

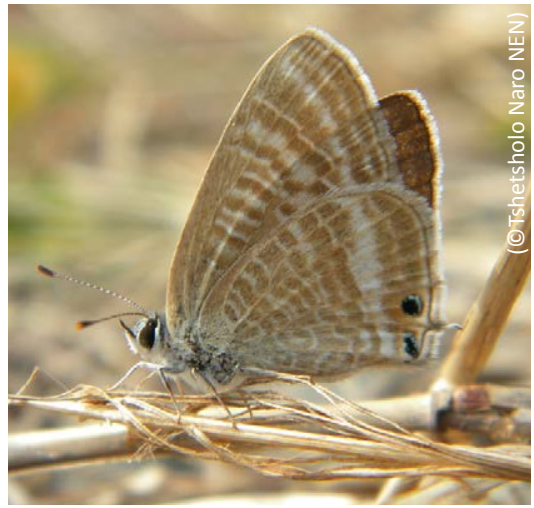

Image 48. Pea Blue Lampides boeticus 


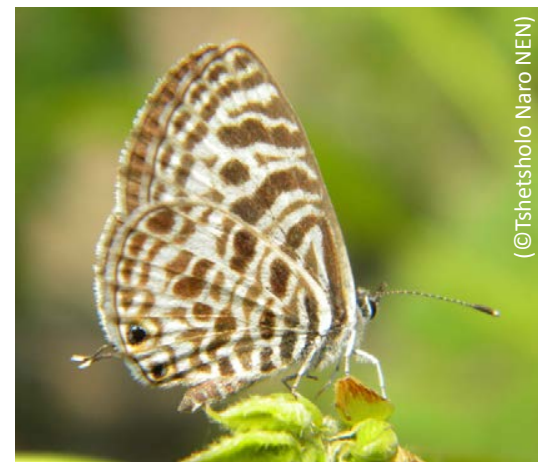

Image 49. Zebra Blue Leptotes plinius plinius

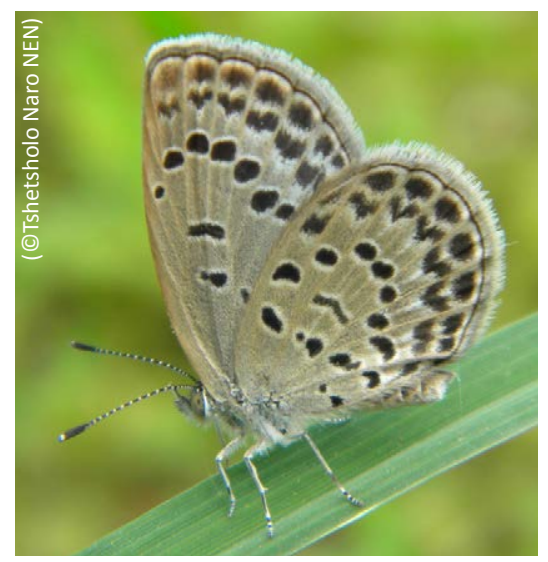

Image 52. Dark Grass Blue Zizeeria karsandra

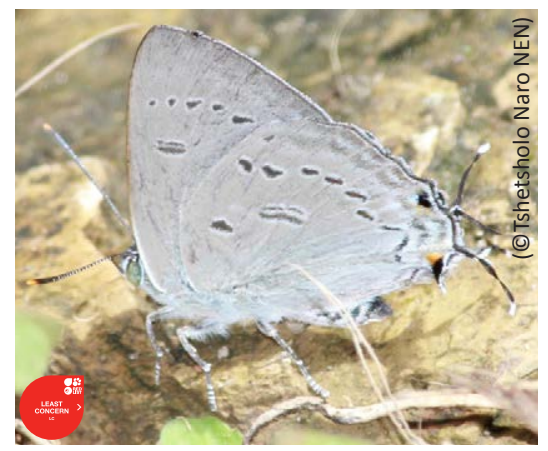

Image 55. Bi-Spot Royal Ancema ctesia ctesia

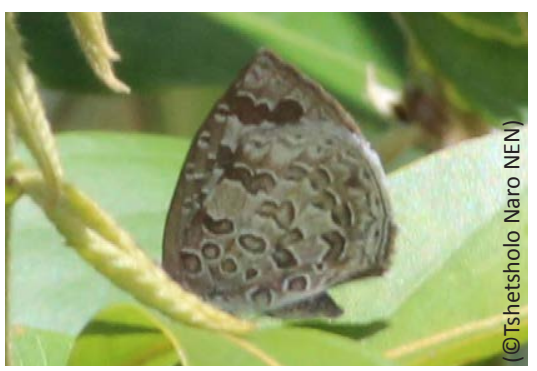

Image 58. Tailess Bushblue Arhopala ganesa watsoni

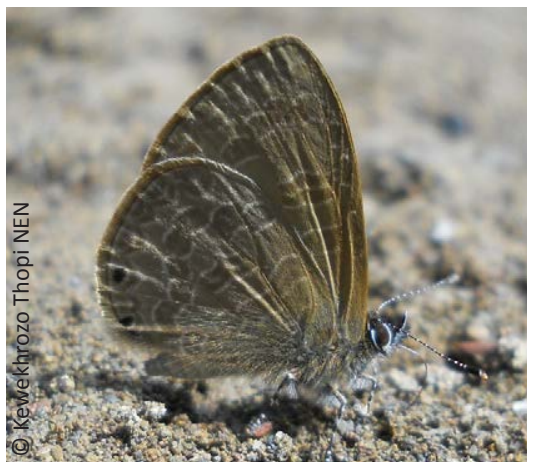

Image 50. Dingy Lineblue Petrelaea dana

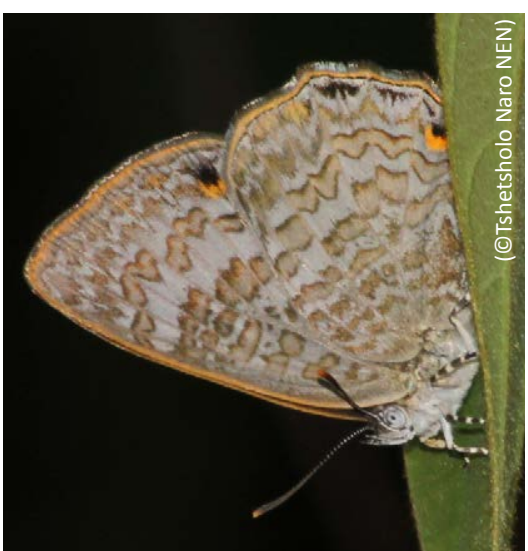

Image 53. Common Gem Poritia hewitsoni hewitsoni

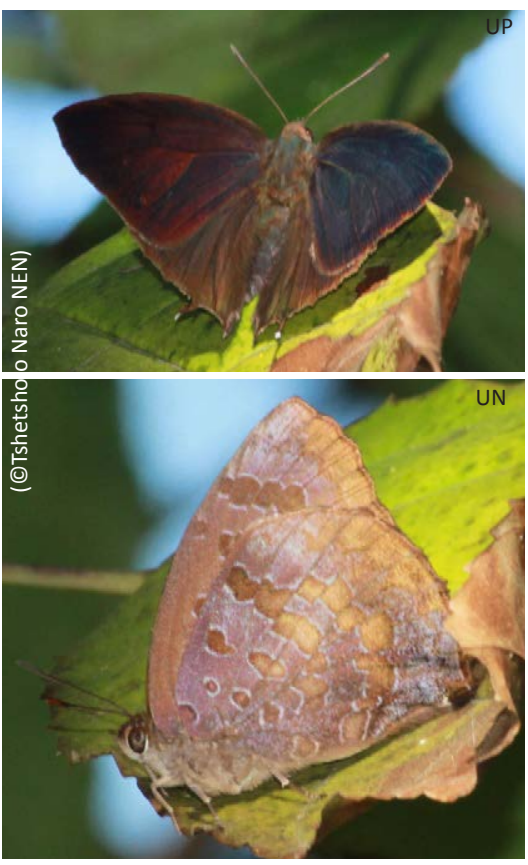

Image 56. Powdered Oakblue Arhopala bazalus teetsa

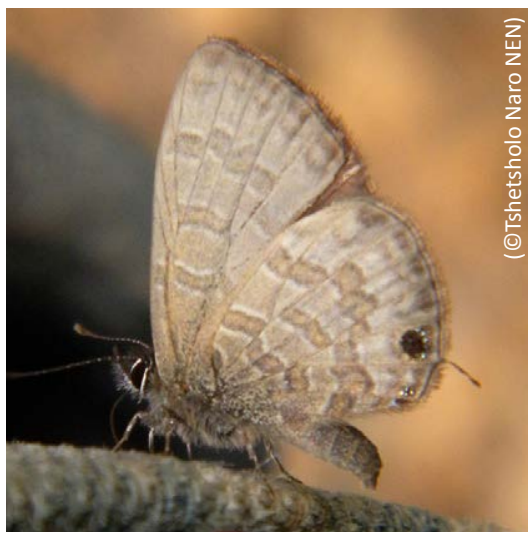

Image 51. Common Lineblue Prosotas nora ardates

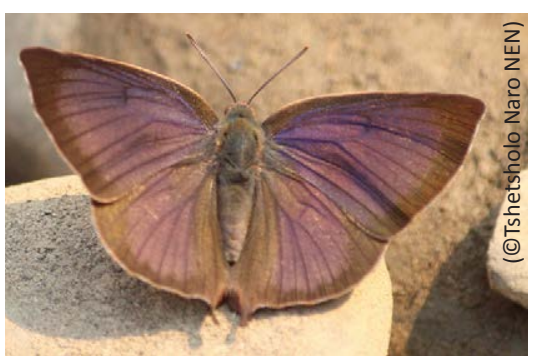

Image 54. Leaf Blue Amblypodia anita dina
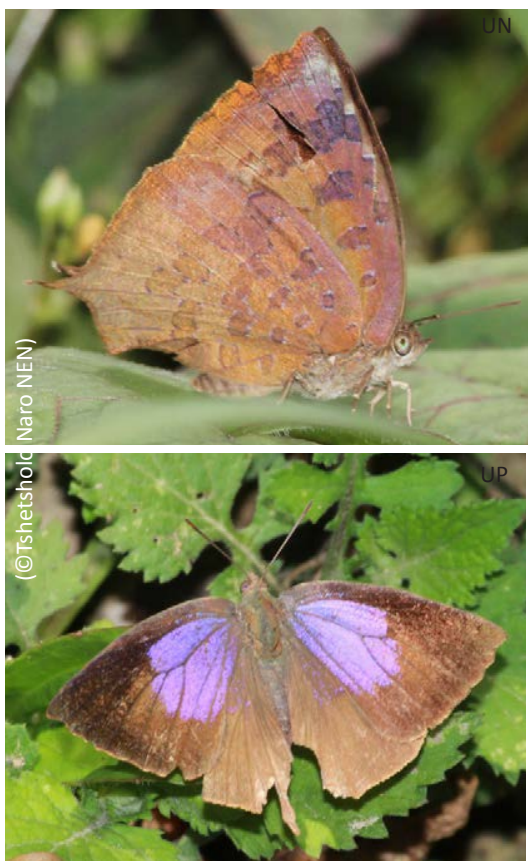

Image 57. Comic Oakblue Arhopala comica 


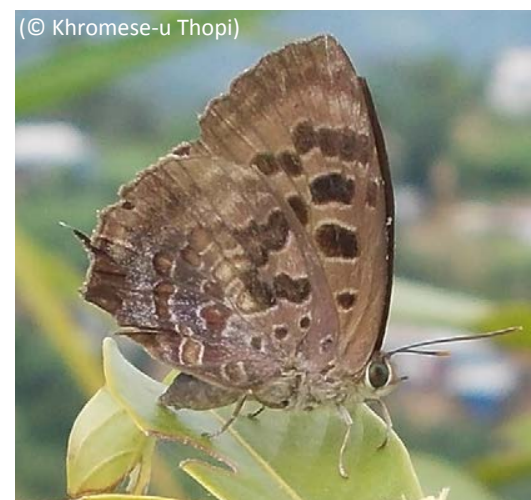

Image 59. Yellowdisc Oakblue Arhopala singla

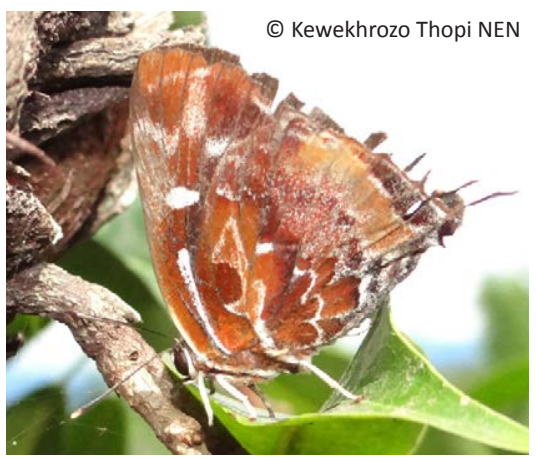

Image 62. Silveratreak Blue Iraota timoleon timoleon

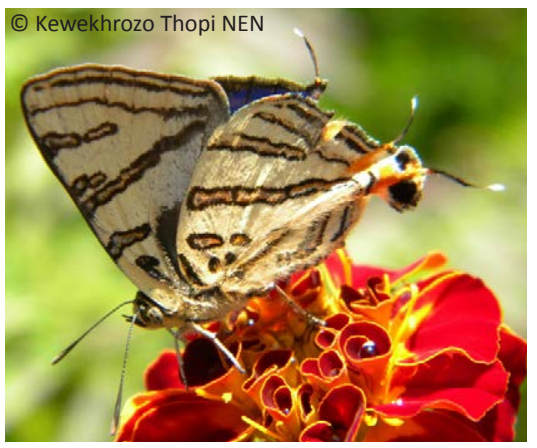

Image 64. Khaki Silverline Spindasis rukmini

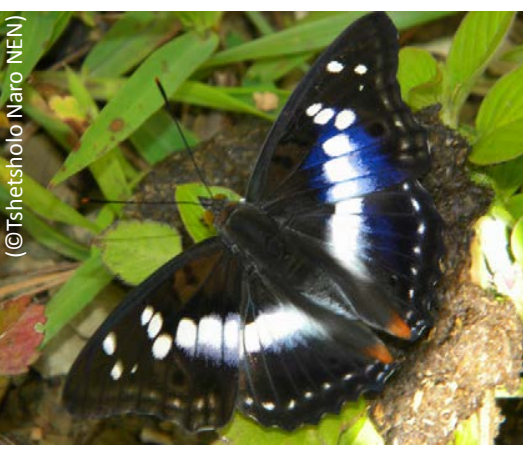

Image 67. Purple Emperor Apatura ambica ambica

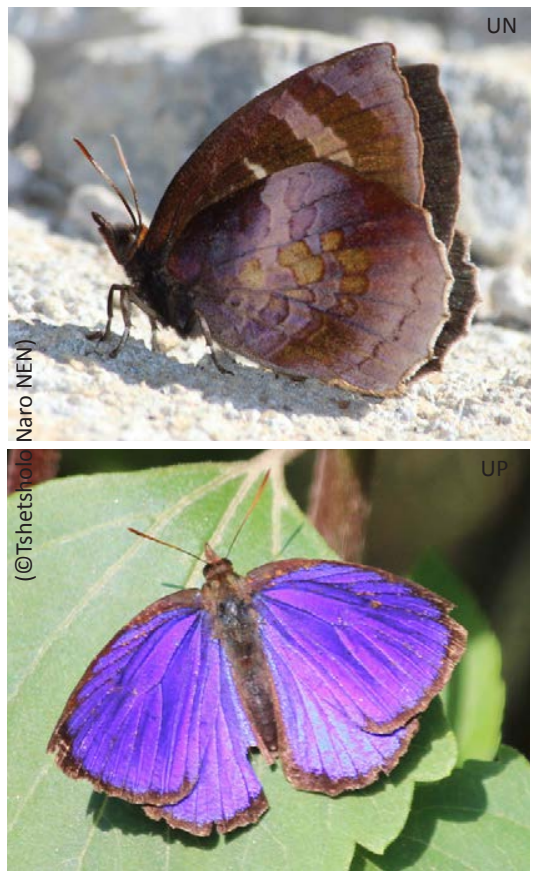

Image 60. Tailless Plushblue Flos areste

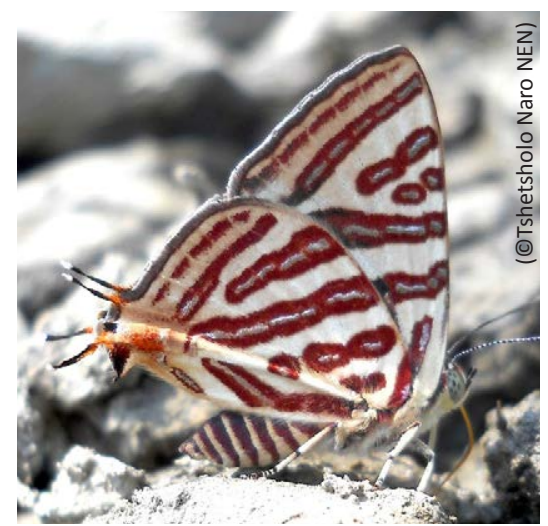

Image 65. Club Silverline Spindasis syama peguanus

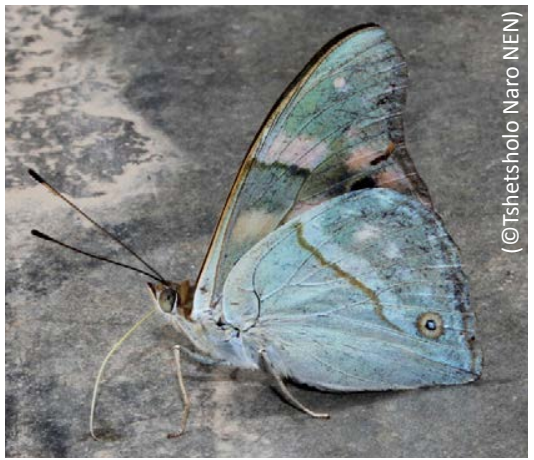

Image 68. Tawny Emperor Chitoria ulupi ulupi

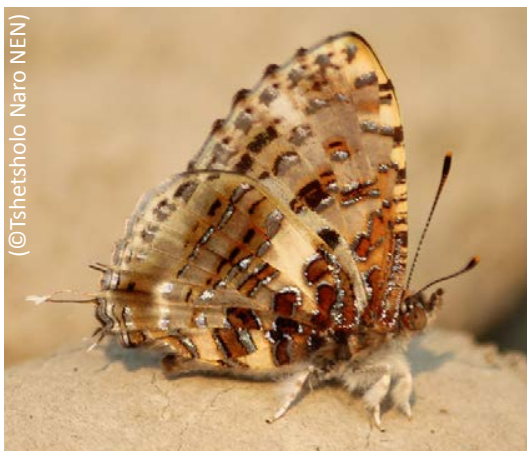

Image 61. Common Tinsel Catapaecilma major major

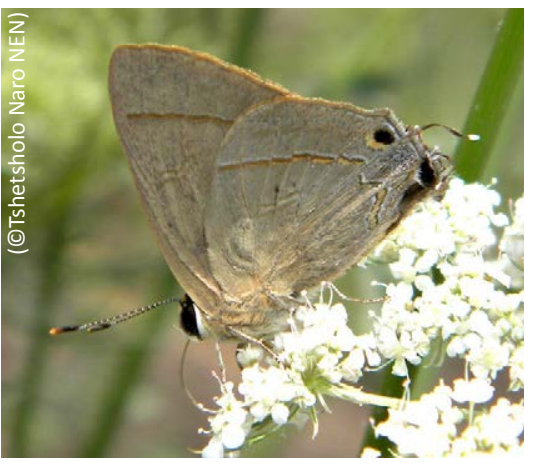

Image 63. Common Flash Rapala nissa nissoides

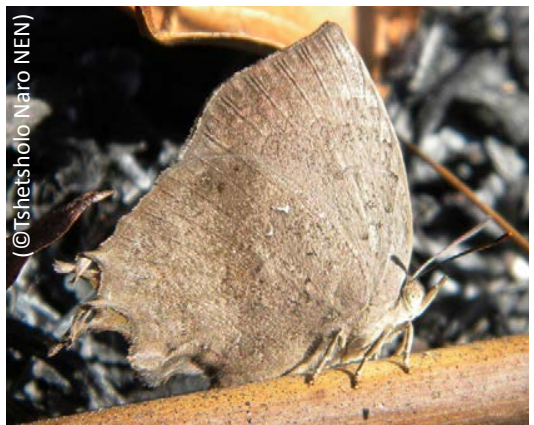

mage 66. Common Acacia Blue Surendra quercetorum quercetorum

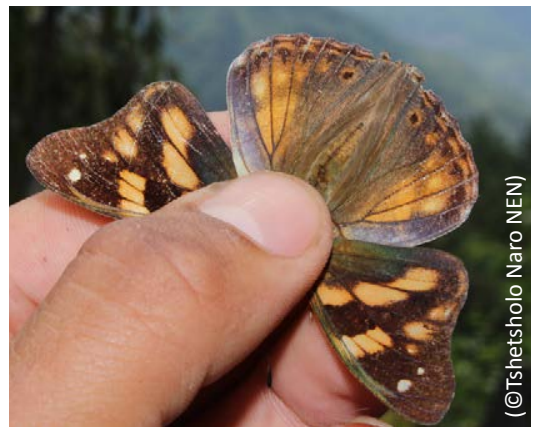

Image 68. Tawny Emperor Chitoria ulupi ulupi 


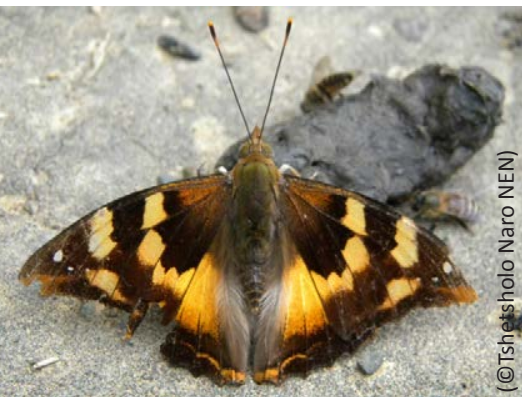

Image 69. Golden Emperor Dilipia morgiana

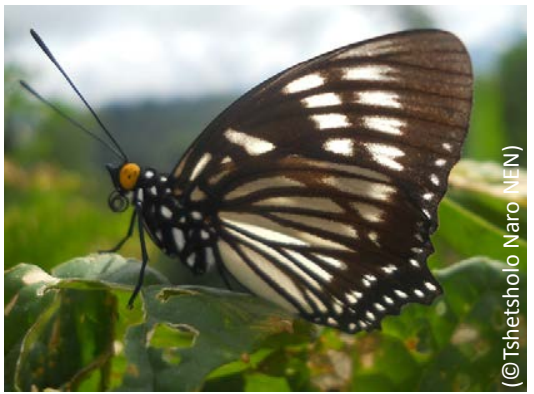

Image 71. Courtesan Euripus nyctelius nyctelius

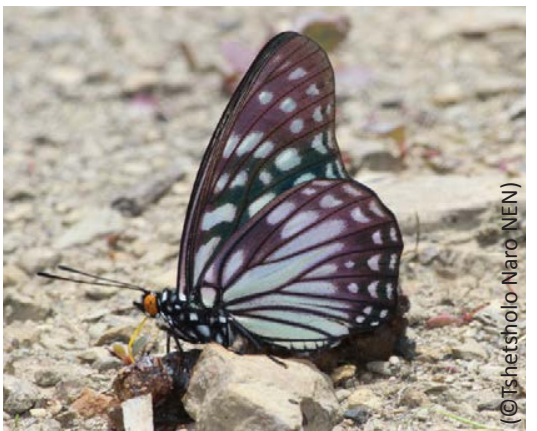

Image 74. Siren Hestina persimilis persimilis

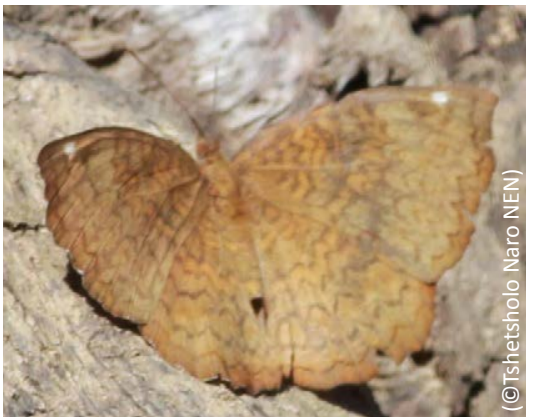

Image 78. Common Castor Ariadne merione tapestrina
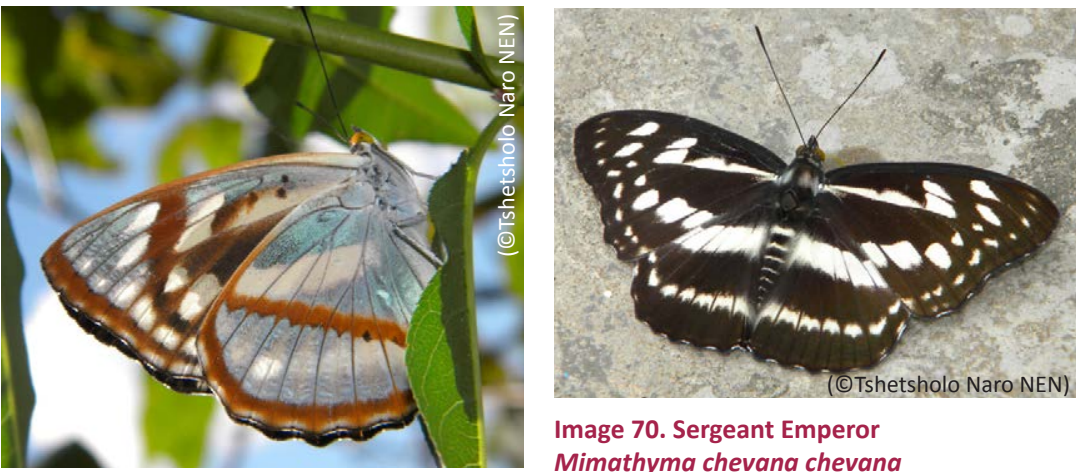

Image 70. Sergeant Emperor

Mimathyma chevana chevana

Image 70. Sergeant Emperor

Mimathyma chevana chevana

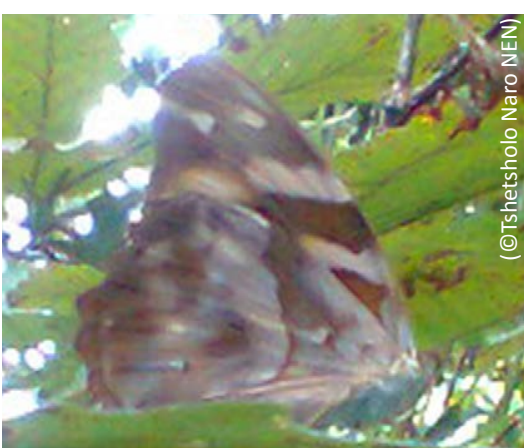

Image 72. Pasha Herona marathus marathus

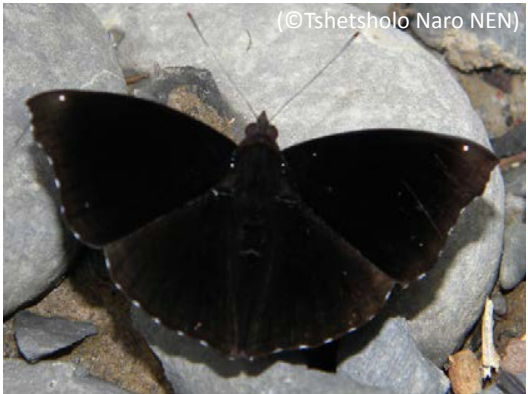

Image 75. Black Prince Rohana parisatis parisatis

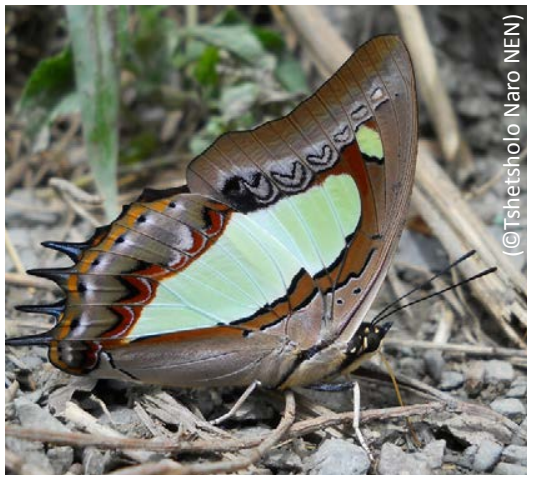

Image 79. Common Nawab Charaxe athamas athamas

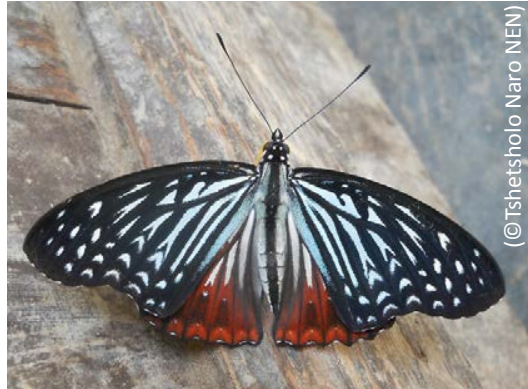

Image 73. Circe Hestinalis nama nama

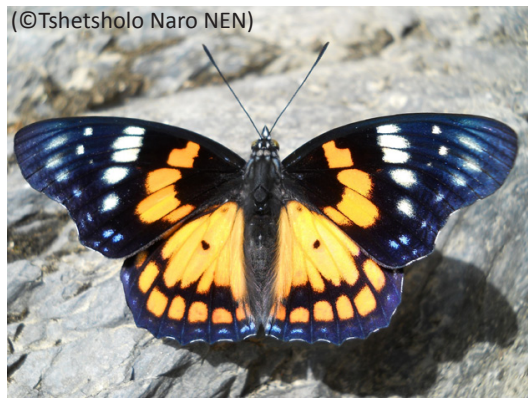

Image 76. Eastern Courtier Sephisa chandra chandra

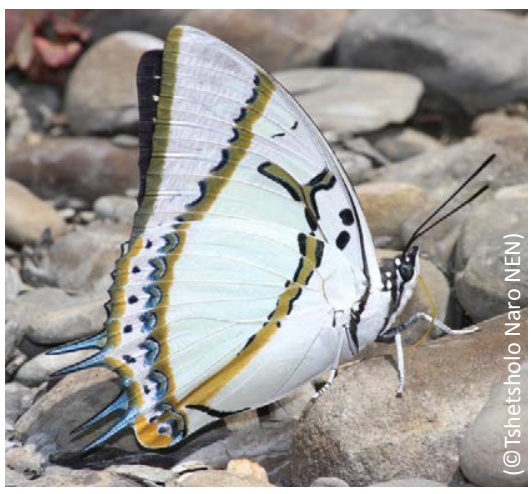

Image 80. Great Nawab Charaxes eudamippus eudamippus 


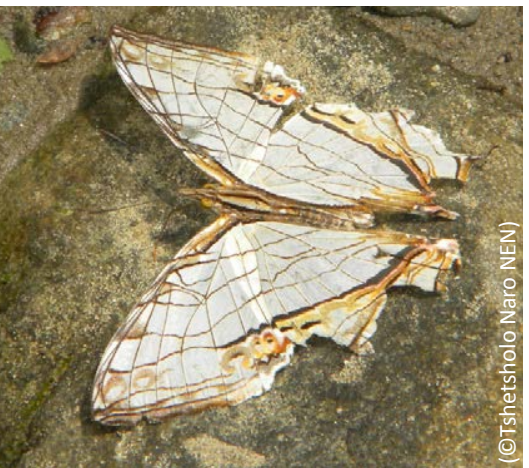

Image 81. Common Map Cyrestis thyodamas thyodamas

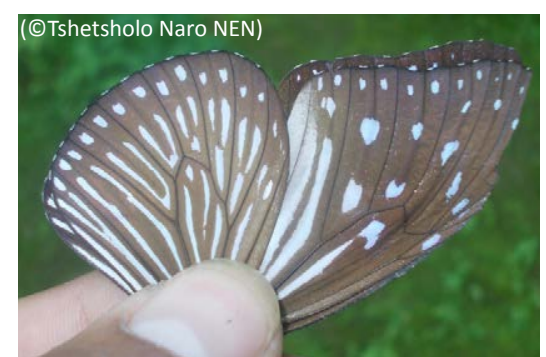

Image 84. Striped Blue Crow Euploea mulciber mulciber

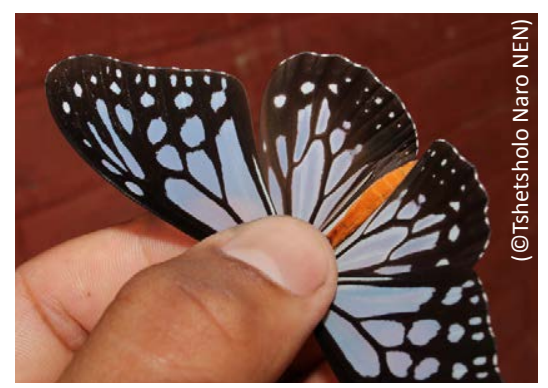

Image 86. Chocolate Tiger Parantica melaneus plataniston

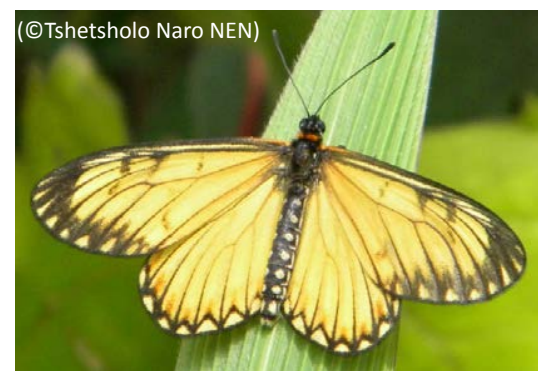

Image 89. Yellow Coster Acraea issoria issoria

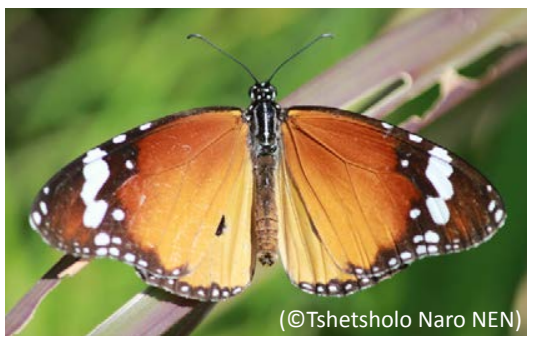

Image 82. Plain Tiger Danaus chrysippus chrysippus

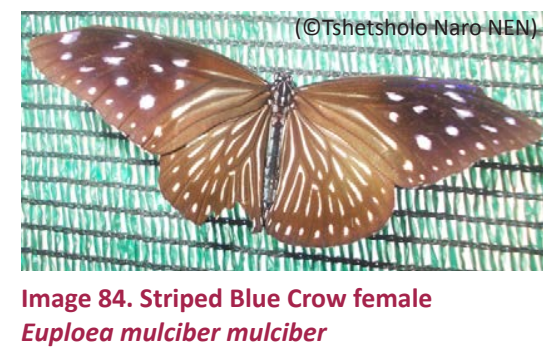

Euploea mulciber mulciber

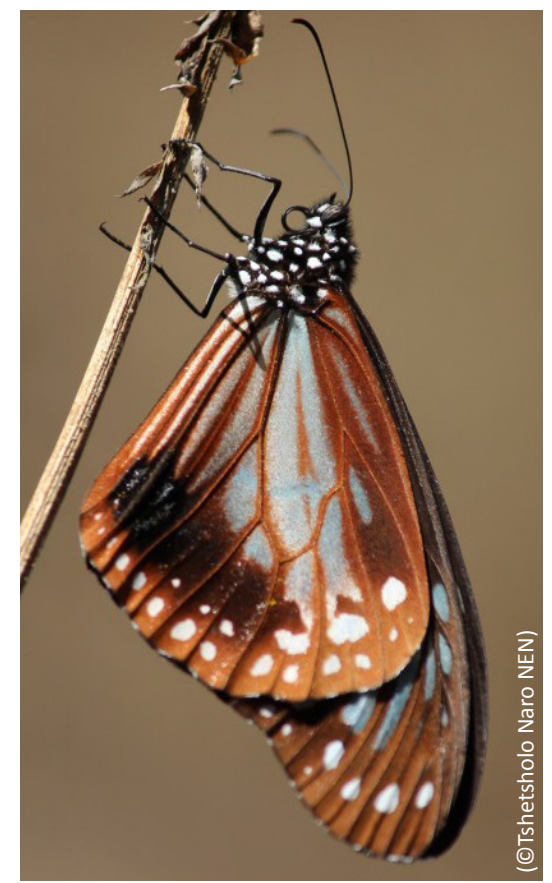

Image 87. Parantica sita sita Chestnut Tiger

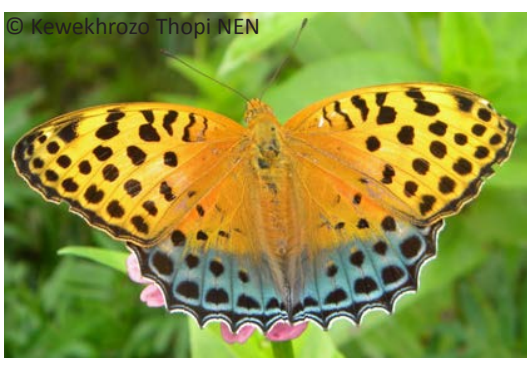

Image 90. Large Silverstrip Argynnis childreni childreni

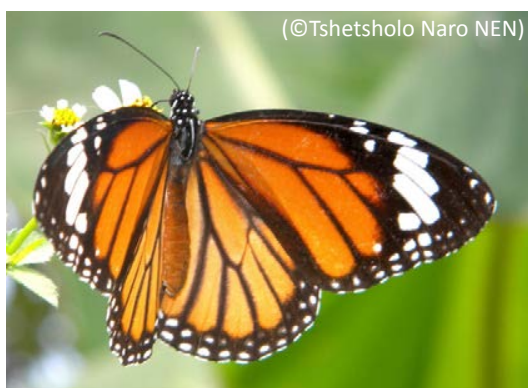

Image 83. Striped Tiger Danaus genutia genutia

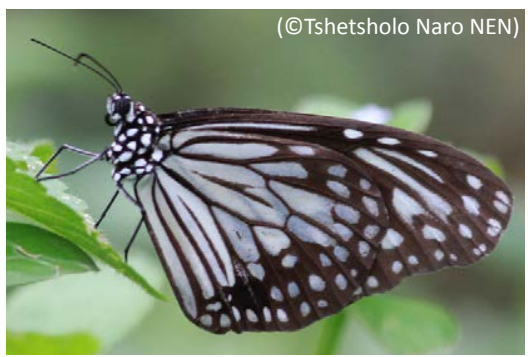

Image 85. Glassy Tiger Parantica aglea melanoides

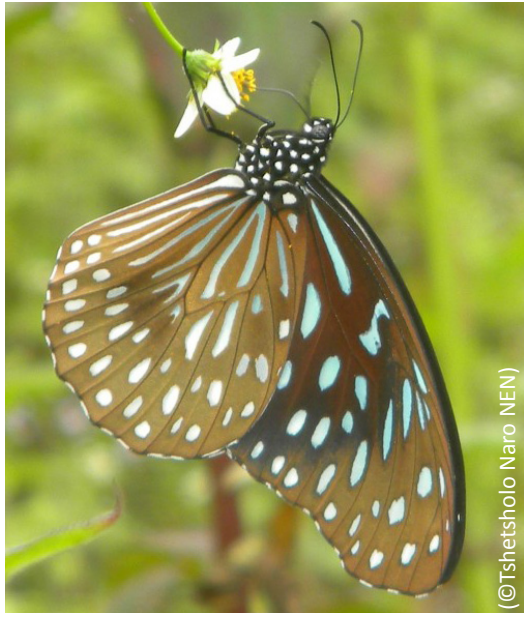

Image 88. Dark Blue Tiger Tirumala septentrionis septentrionis

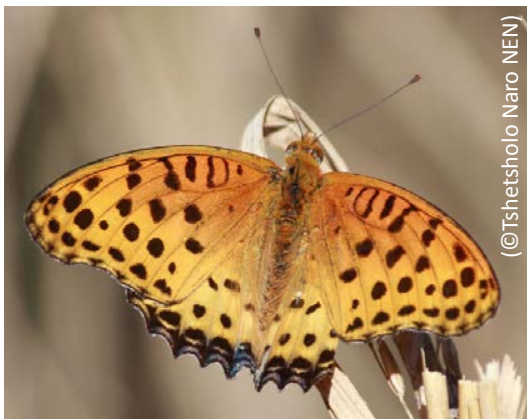

Image 91. Tropical Fritillary Argynnis hyperbius hyperbius 


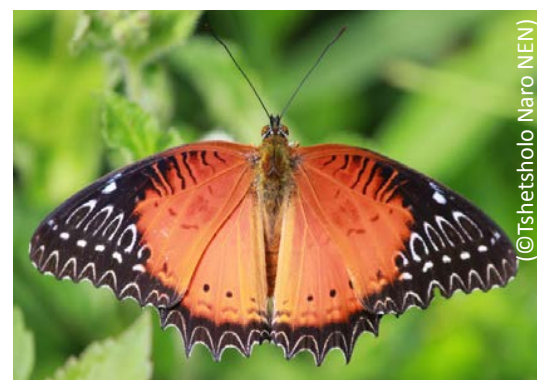

Image 92. Red Lacewing male

Cethosia biblis tisamena

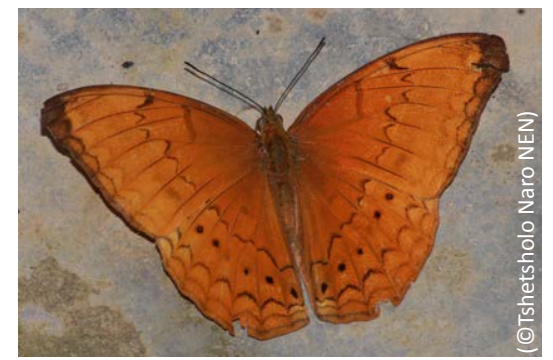

Image 94. Large Yeoman Cirrochroa aoris aoris

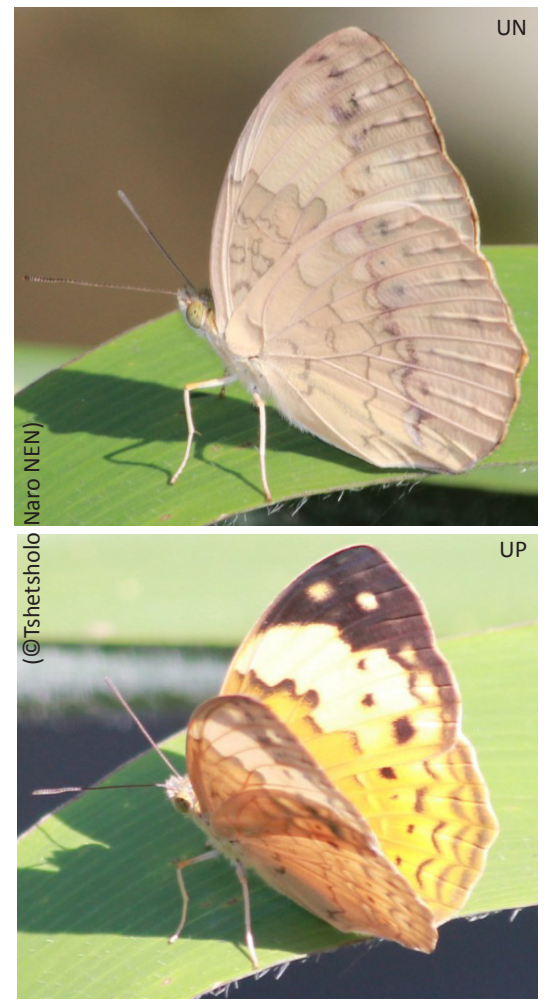

Image 96. Rustic Cupha erymanthis lotis

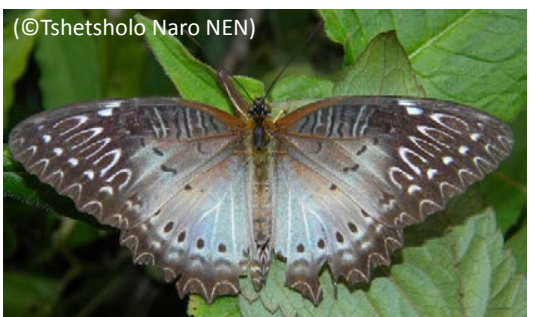

Image 92. Red lacewing female Cethosia biblis tisamena

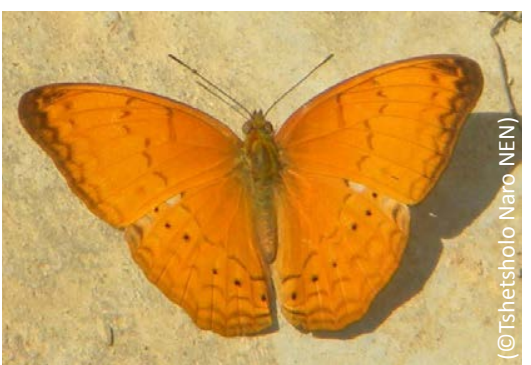

Image 95. Common Yeoman Cirrochroa tyche mithila

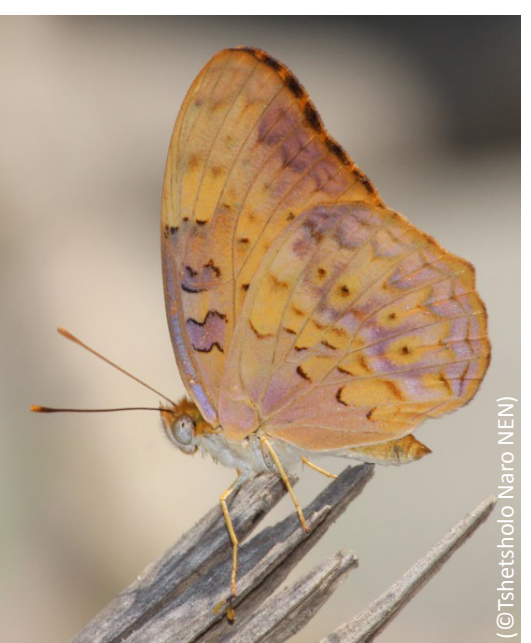

Image 97. Common Leopard Phalanta phalantha phalantha

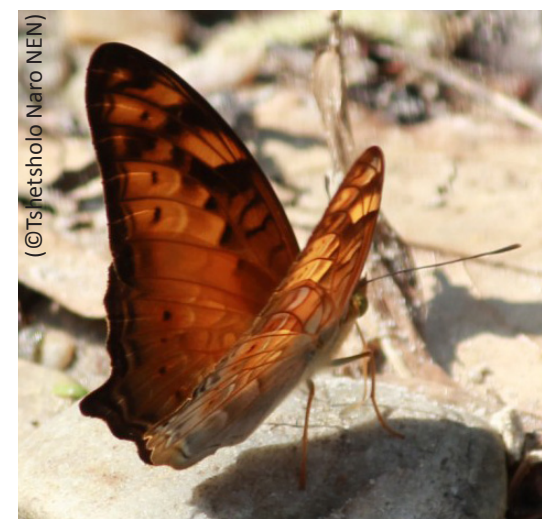

Image 98. Vagrant Vagrans egista sinha
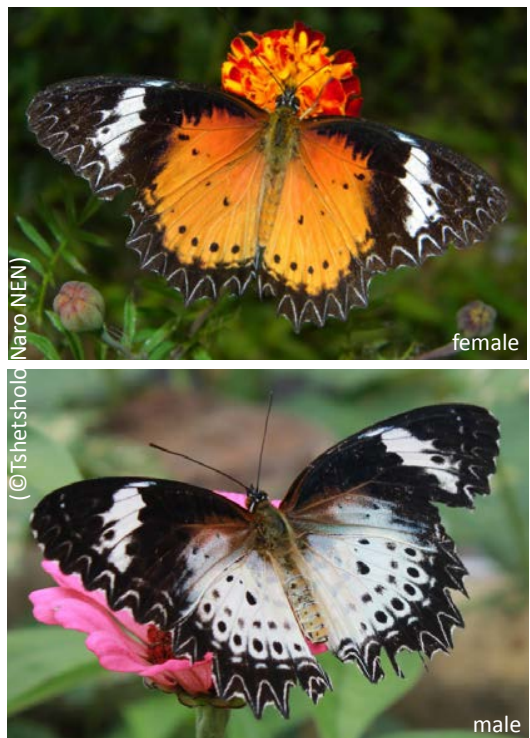

Image 93. Leopard Lacewing Cethosia cyane cyane
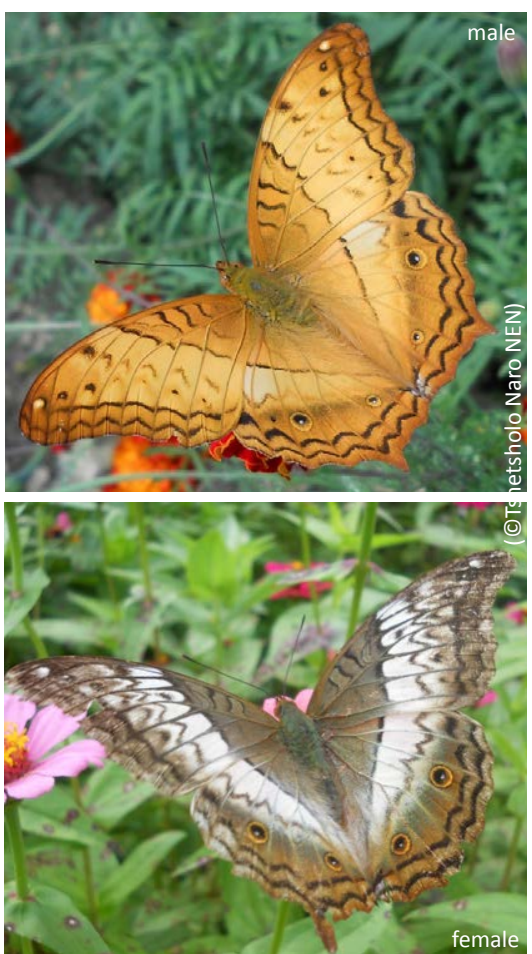

Image 99. Cruiser Vindula erota erota 


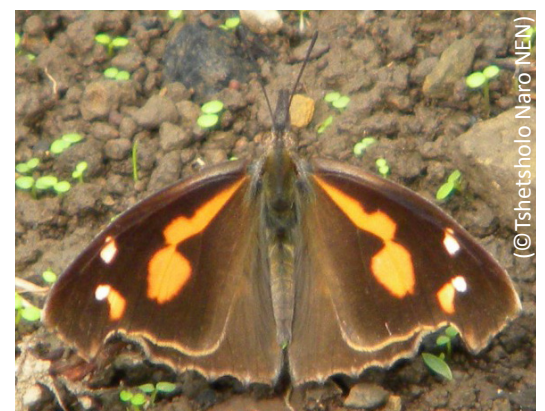

Image 100. Common Beak Libythea lepita lepita

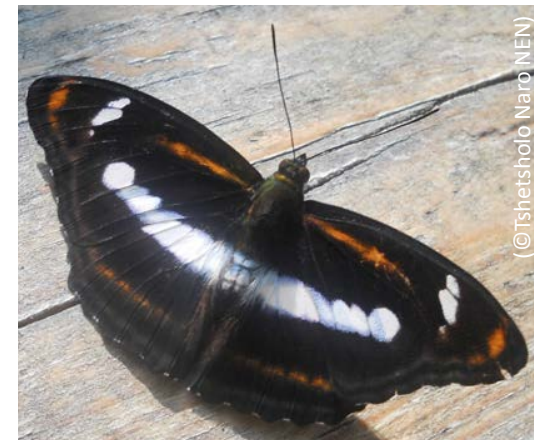

Image 103. Orange Staff Sergeant male Athyma cama cama

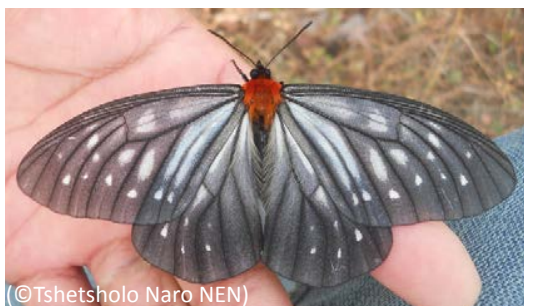

Image 105. Freak Calinaga brahma brahma

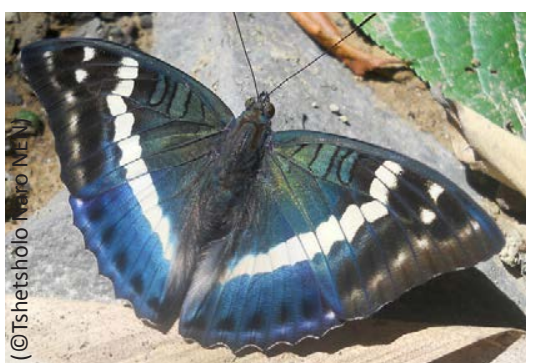

Image 107. French Duke Euthalia franciae franciae

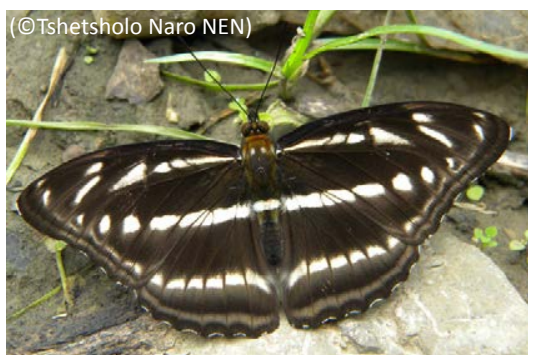

Image 101. Himalayan Sergeant Athyma opalina orientalis

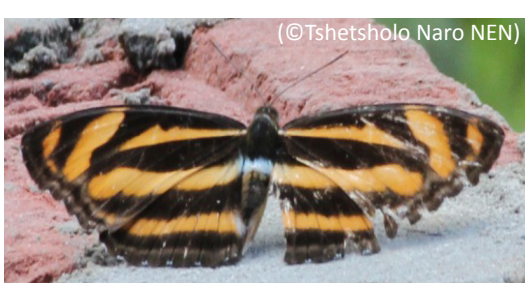

Image 103. Orange Staff Sergeant female Athyma cama cama

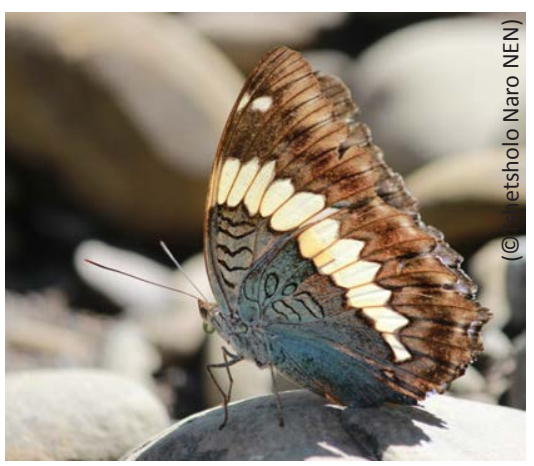

Image 106. Blue Duke Bassarona durga splendens

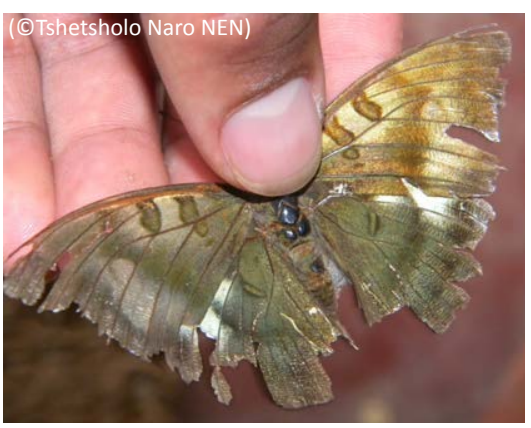

Image 108. Bronze Duke Euthalia nara nagaensis

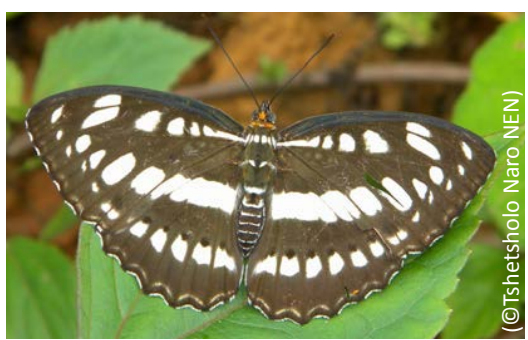

Image 102. Common Sergeant Athyma perius perius

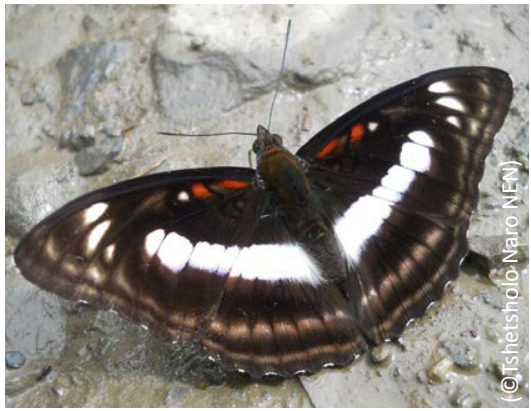

Image 104. Staff Sergeant Athyma selenophora selenophora

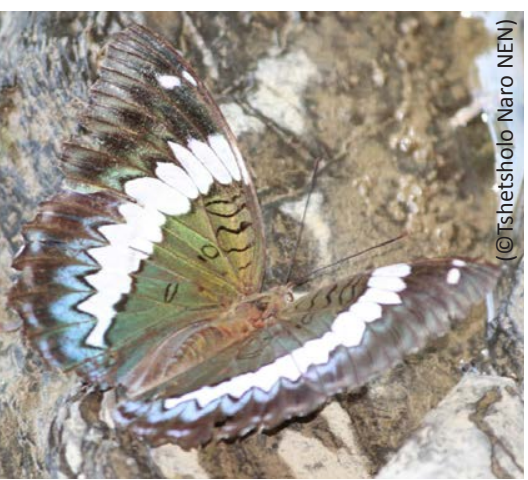

mage 106. Blue Duke Bassarona durga splendens

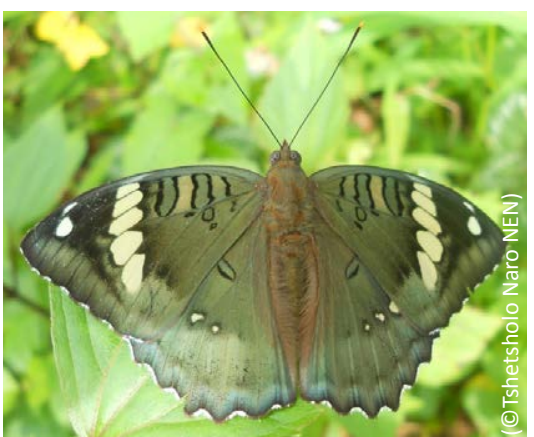

Image 109. Green Duke Euthalia sahadeva nadaka 


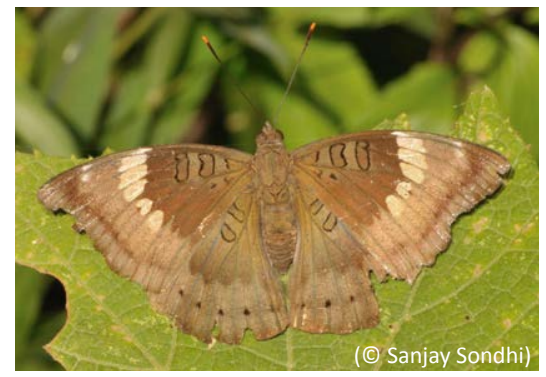

Image 110. Common Baron Euthalia aconthea garuda

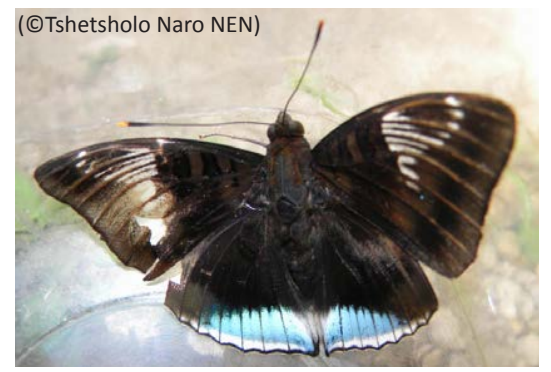

Image 112. White-edged Blue Baron Euthalia phemius phemius

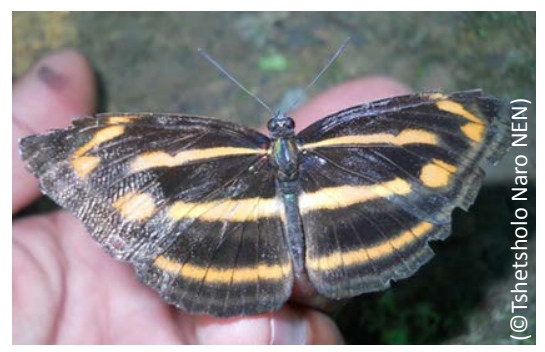

Image 114. Namba Sailer Neptis cf. namba namba

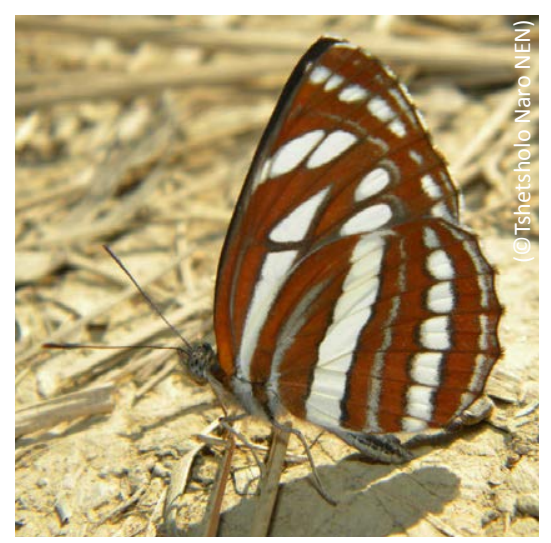

Image 116. Pallas' Sailer Neptis sappho astola

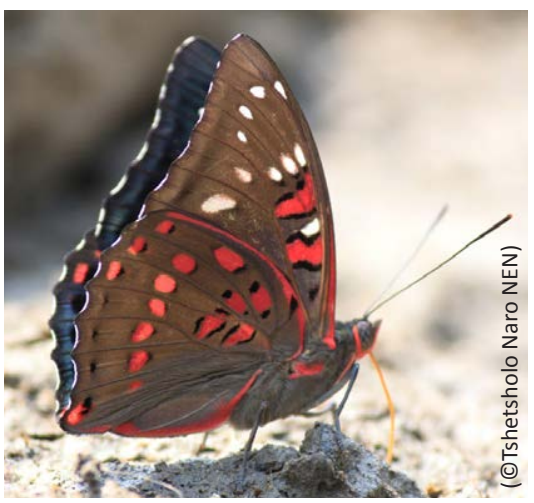

Image 111. Gaudy Baron Euthalia lubentina lubentina

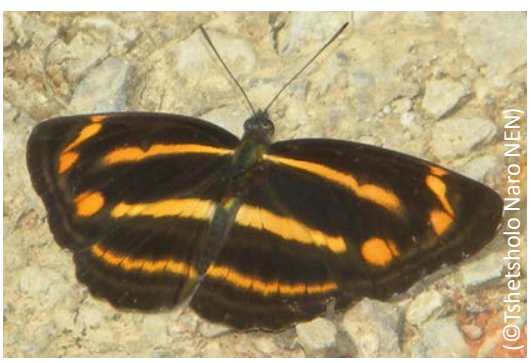

Image 113. Yellow Sailor Neptis ananta ochracea

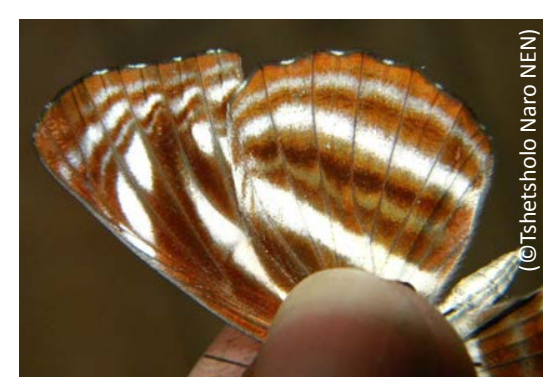

Image 115. Broad-banded Sailer Neptis sankara ambo

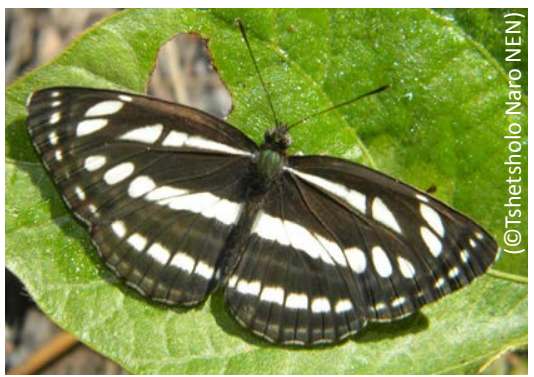

Image 116. Pallas' Sailer Neptis sappho astola

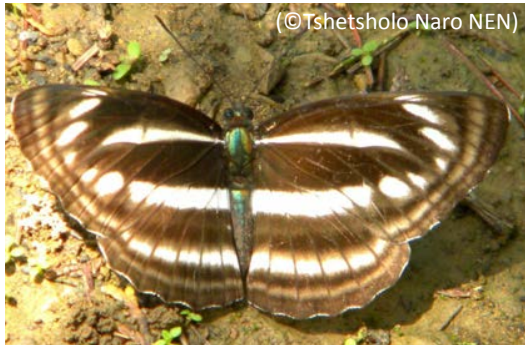

Image 115. Broad-banded Sailer Neptis sankara amba

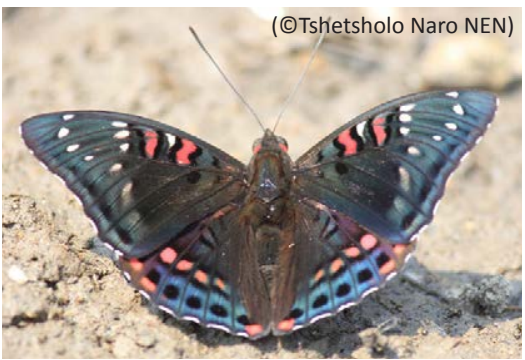

Image 111. Gaudy Baron Euthalia Iubentina lubentina

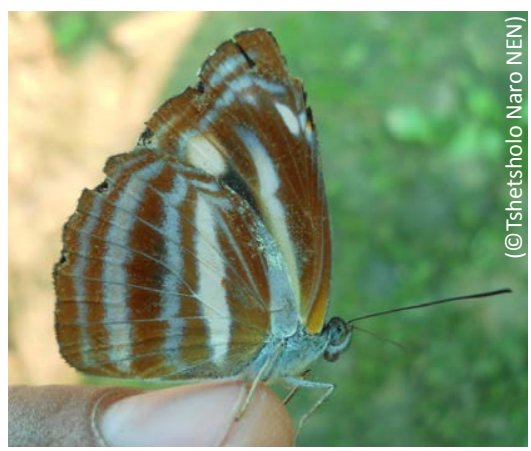

Image 114. Namba Sailer Neptis cf. namba namba

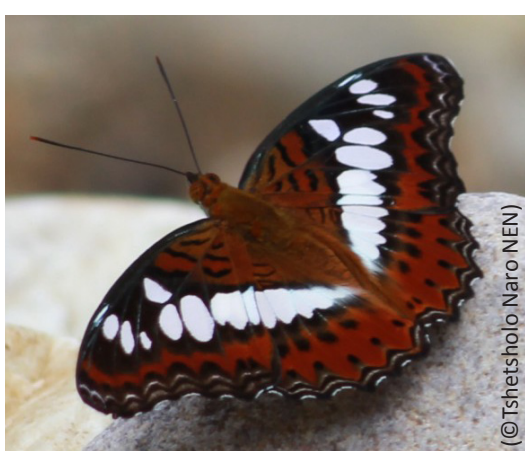

Image 117. Commander Moduza procris procris 


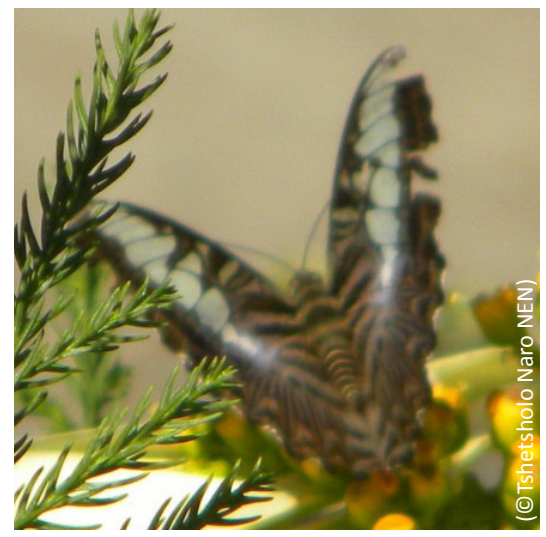

Image 118. Clipper Parthenos sylvia gambrisius

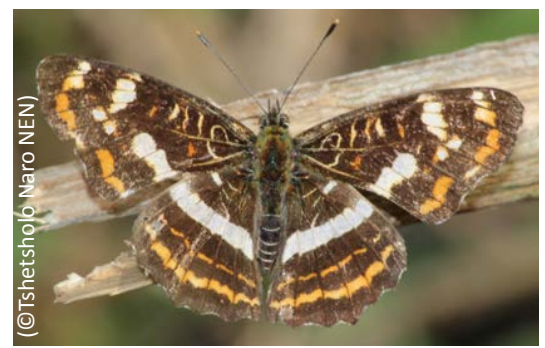

Image 120. Mongol Araschnia prorsoides dohertyi

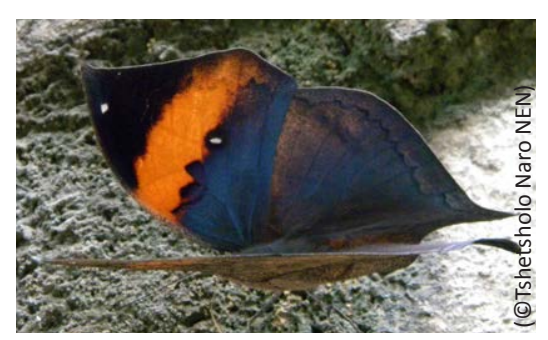

Image 122. Orange Oakleaf Kallima inachus inachus

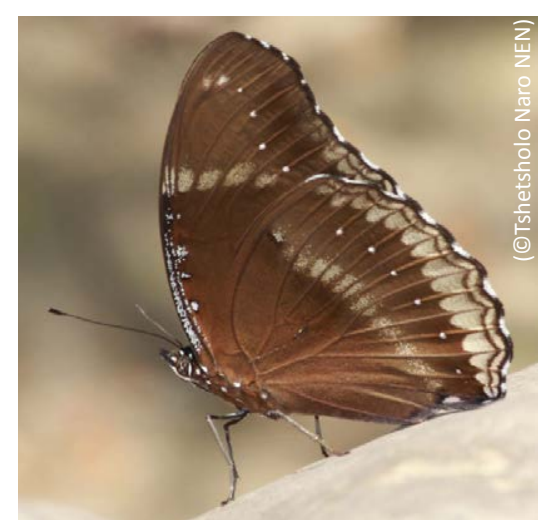

Image 124. Great Eggfly Hypolimnas bolina jacintha

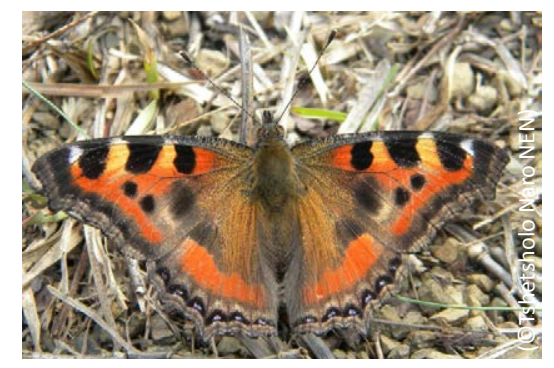

Image 119. Indian Tortoiseshell Aglais caschmirensis aesis

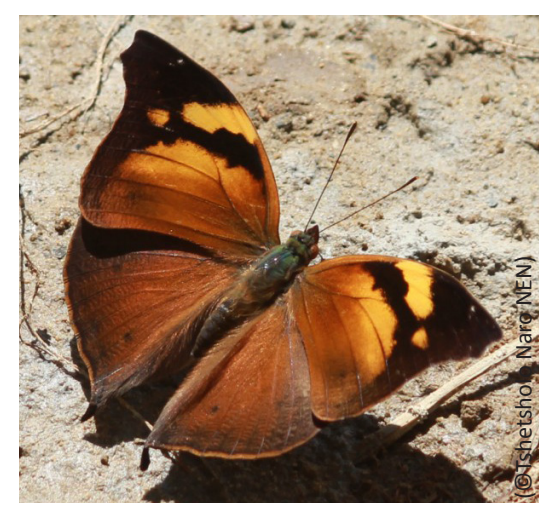

Image 121. Autumn Leaf Doleschallia bisaltide indica

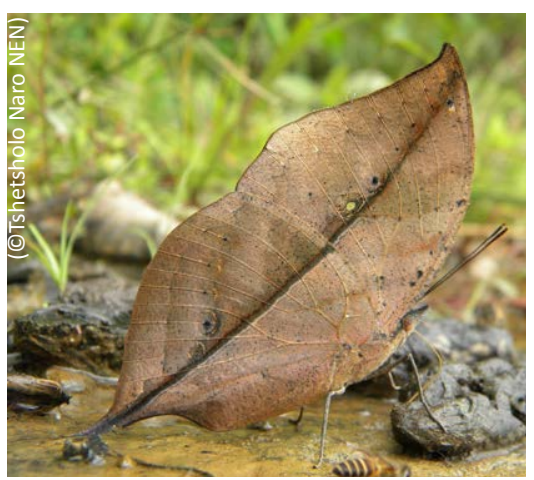

Image 123. Scarce Blue Oakleaf Kallima knyvettii

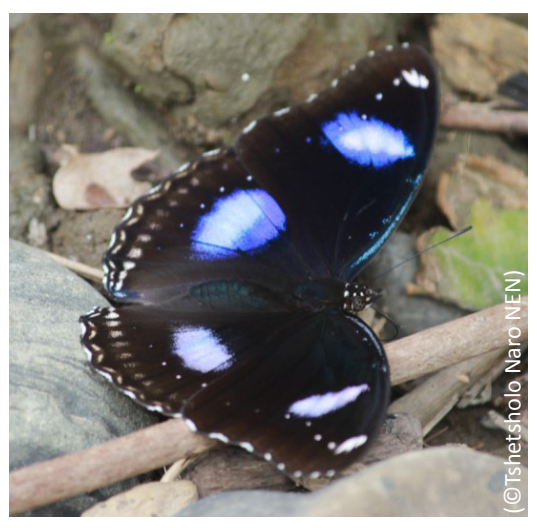

Image 124. Great Eggfly Hypolimnas bolina jacintha

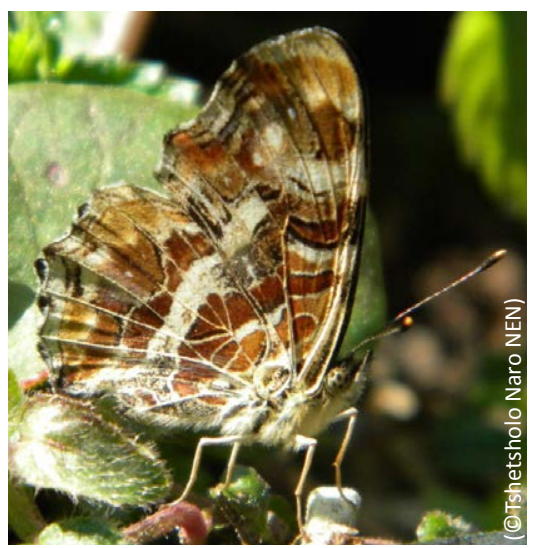

Image 120. Mongol Araschnia prorsoides dohertyi

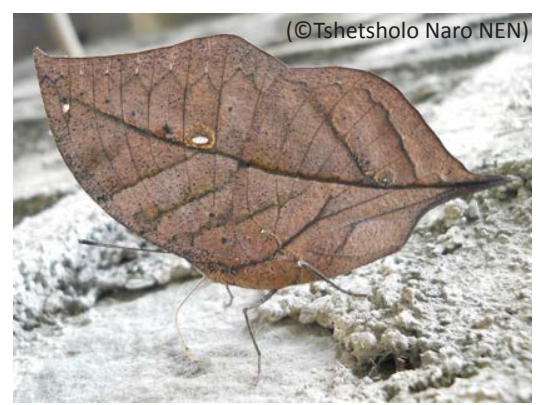

Image 122. Orange Oakleaf Kallima inachus inachus

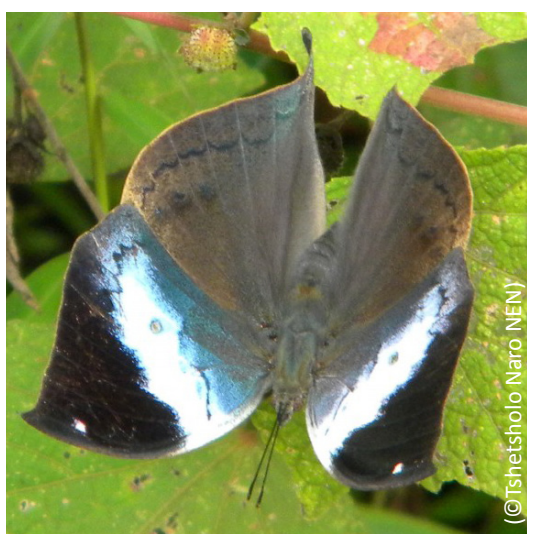

Image 123. Scarce Blue Oakleaf Kallima knyvettii

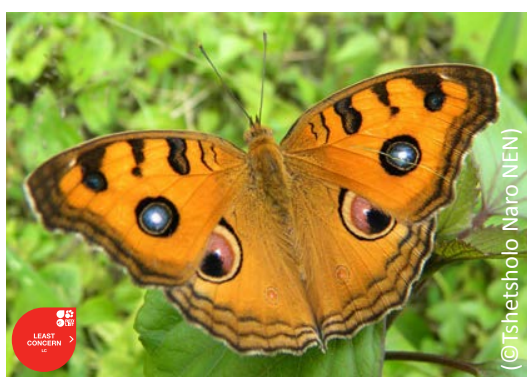

Image 125. Peacock Pansy Junonia almana almana 


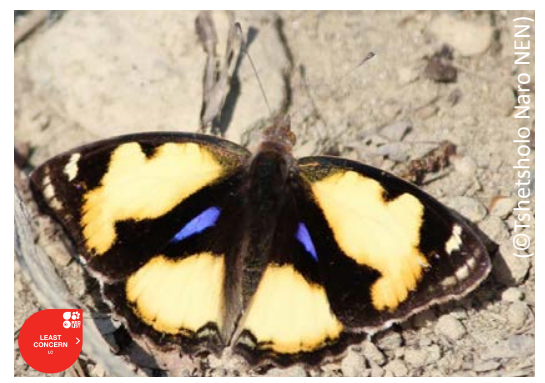

Image 126. Yellow Pansy Junonia hierta hierta

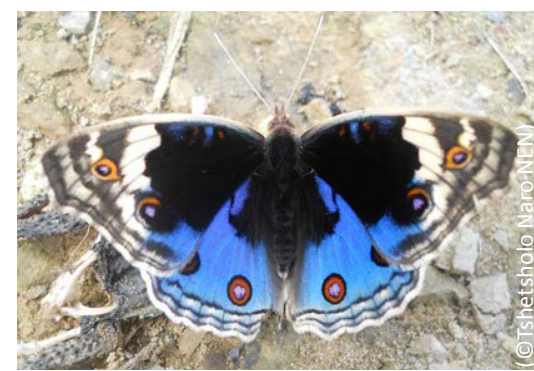

Image 129. Blue Pansy Junonia orithya ocyale

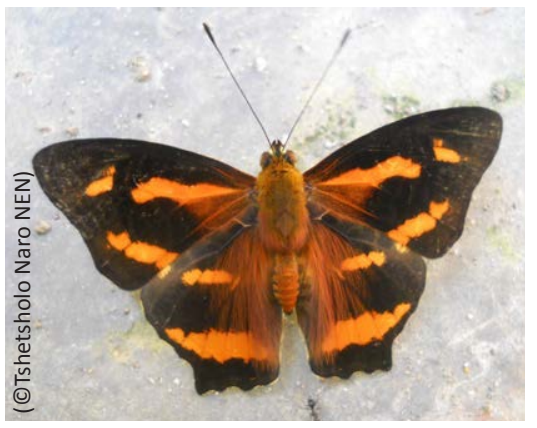

Image 131. Spotted Jester Symbrenthia hypselis cotanda

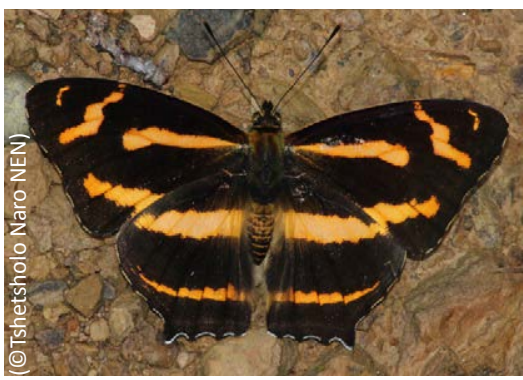

Image 133. Blue-tailed Jester Symbrenthia niphanda niphanda

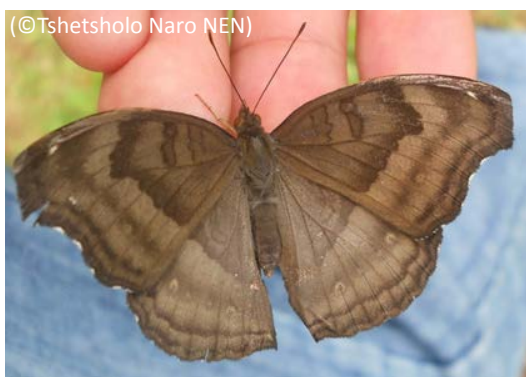

Image 127. Chocolate Pansy Junonia iphito iphita

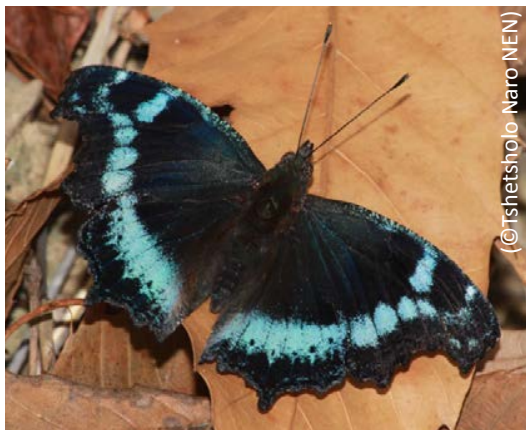

Image 130. Blue Admiral Kaniska canace canace

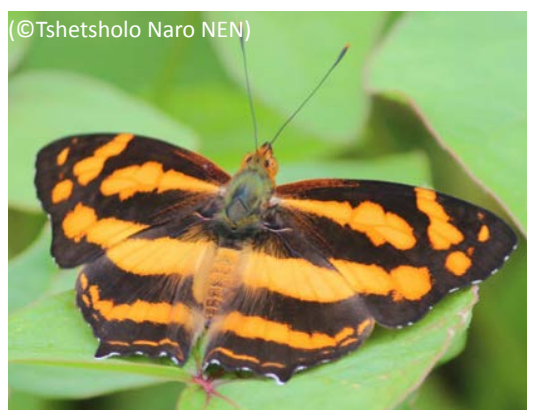

Image 132. Common Jester Symbrenthia lilaea khasiana

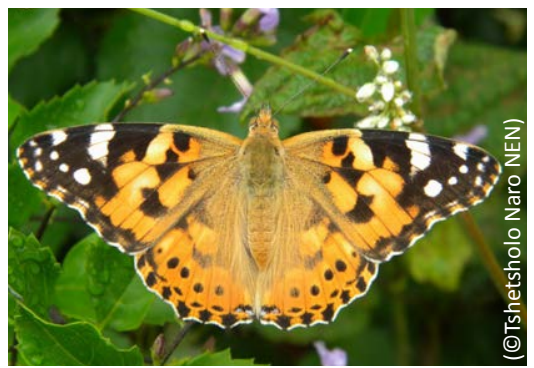

Image 134. Painted Lady Vanessa cardui cardui

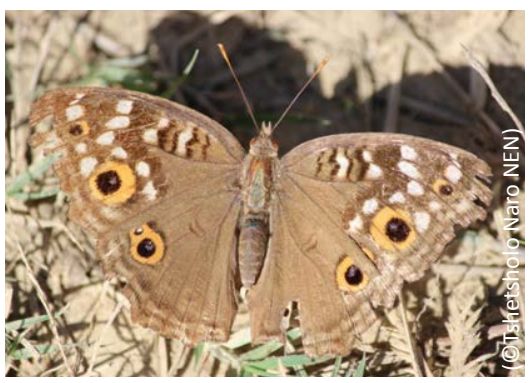

Image 128. Leoman Pansy Junonia lemonias lemonias

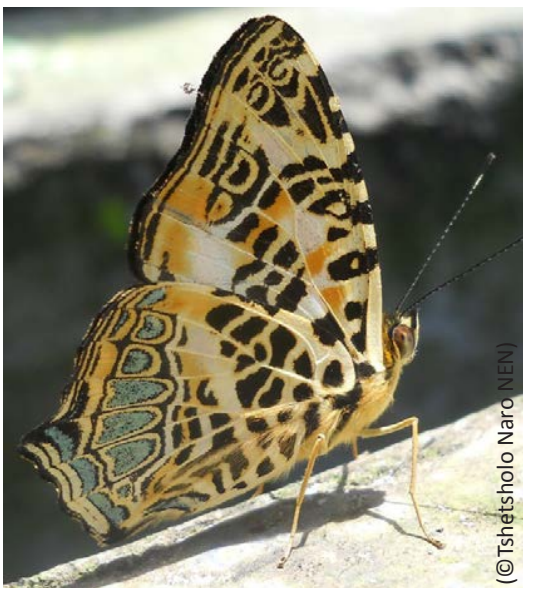

Image 131. Spotted Jester Symbrenthia hypselis cotanda

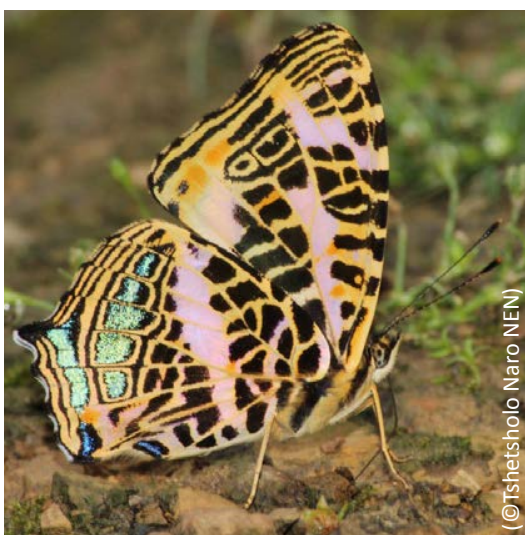

Image 133. Blue-tailed Jester Symbrenthio niphanda niphanda

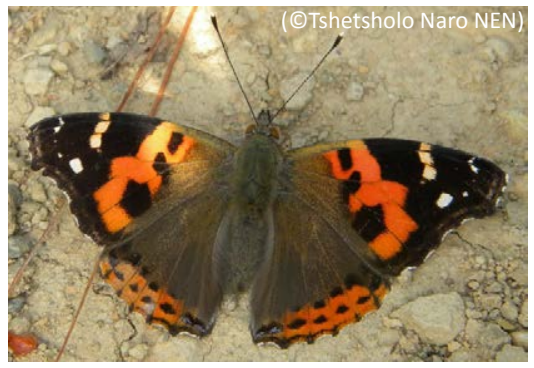

Image 135. Indian Red Admiral Vanessa indica indica 


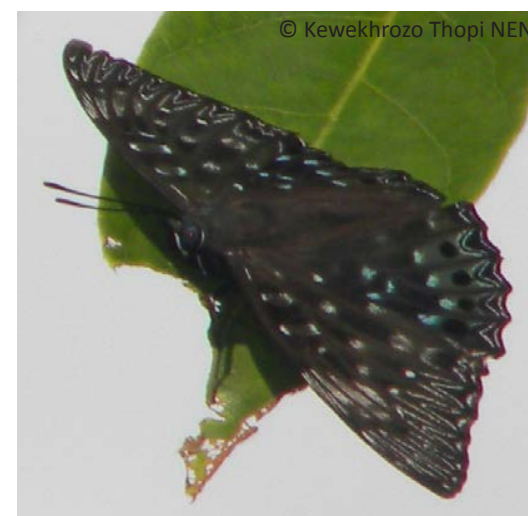

Image 136. Constable Dichorragia nesimachus nesimachus

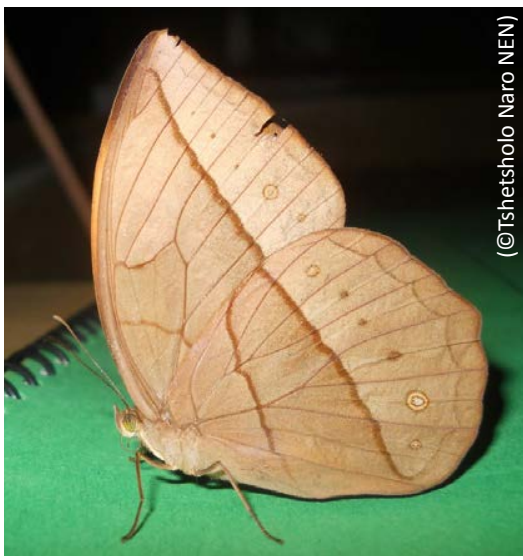

Image 139. Yellow Dryad Aemona amathusia

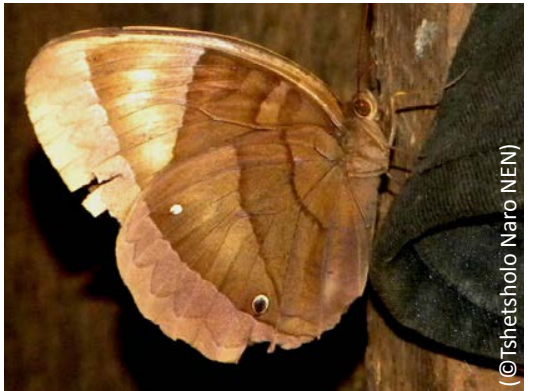

Image 142. Jungle Glory Thaumantis diore diores

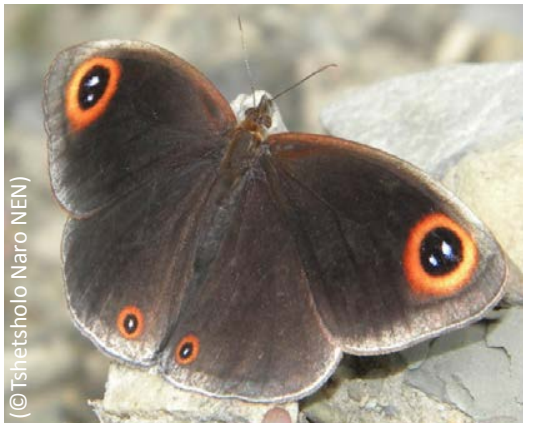

Image 143. Callerebia orixa

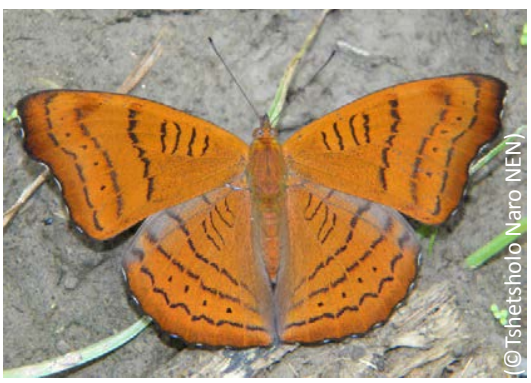

Image 137. Tabby Pseudergolis wedah wedah

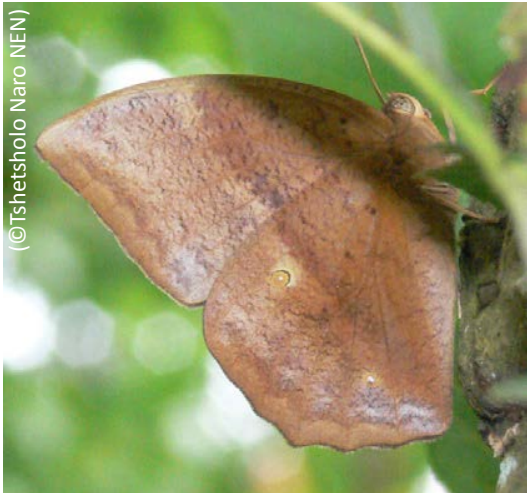

Image 140. Common Duffer Discophora sondaica zal

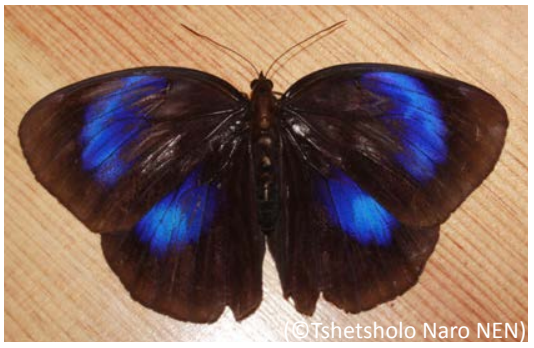

Image 142. Jungle Glory Thaumantis diores diores

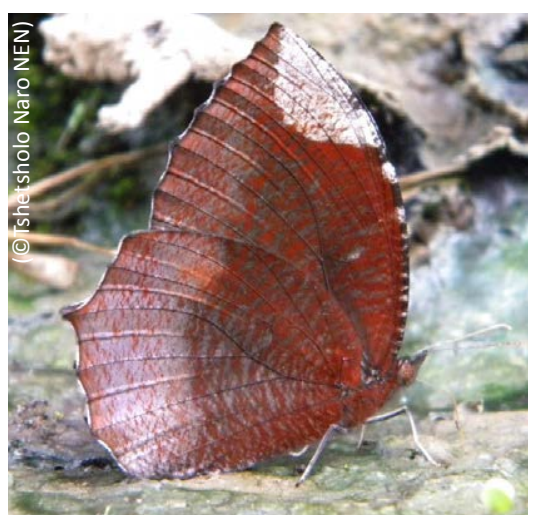

Image 144. Common Palmfly

Elymnias hypermnestra undularis

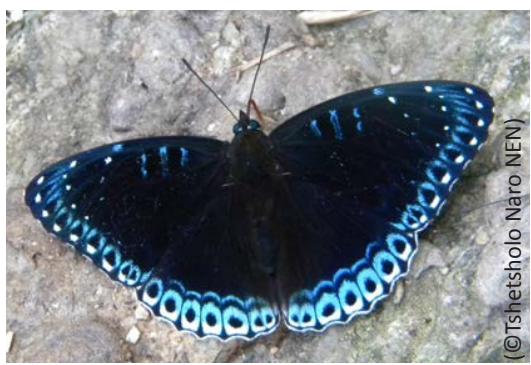

Image 138. Popinjay Stibochiona nicea nicea

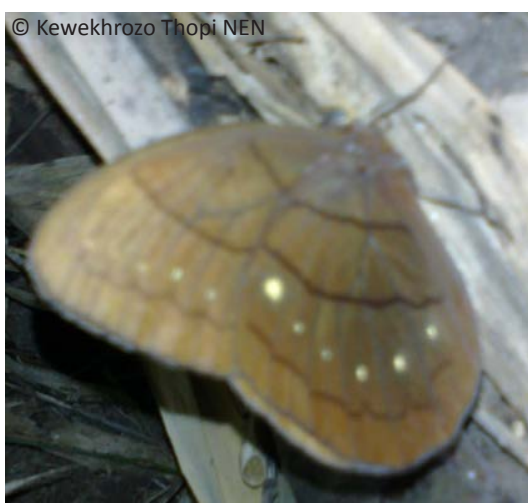

Image 141. Large Faun Faunis eumeus assama

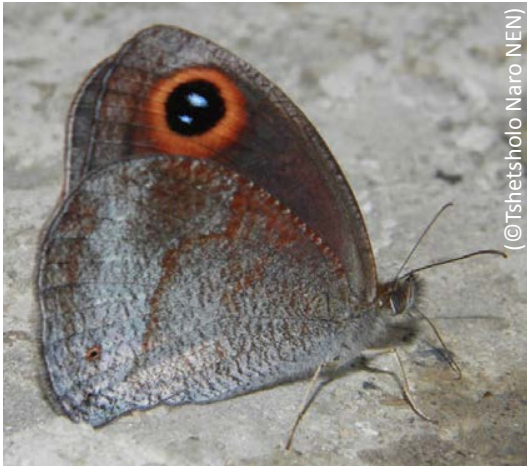

Image 143. Callerebia orixa

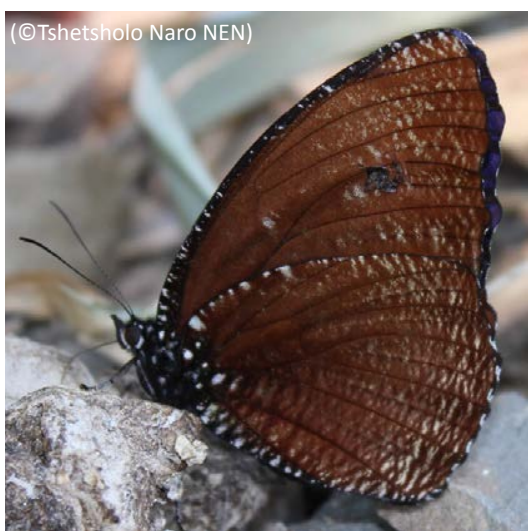

Image 145. Spotted Palmfly

Elymnias malelas malelas 


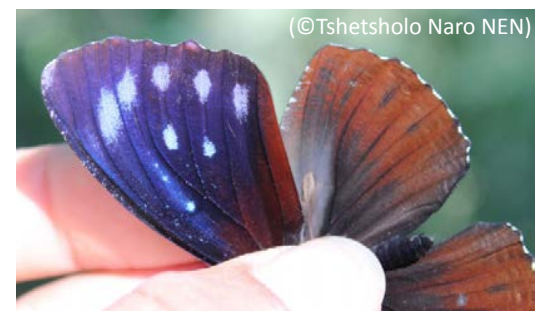

Image 145. Spotted Palmfly Elymnias malelas malelas

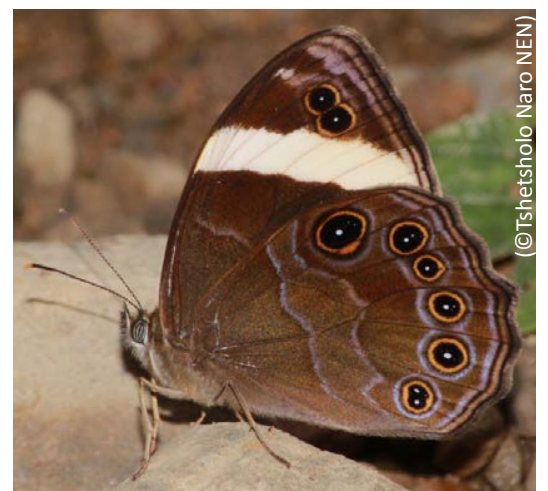

Image 148. Straight-banded Treebrown Lethe verma sintica

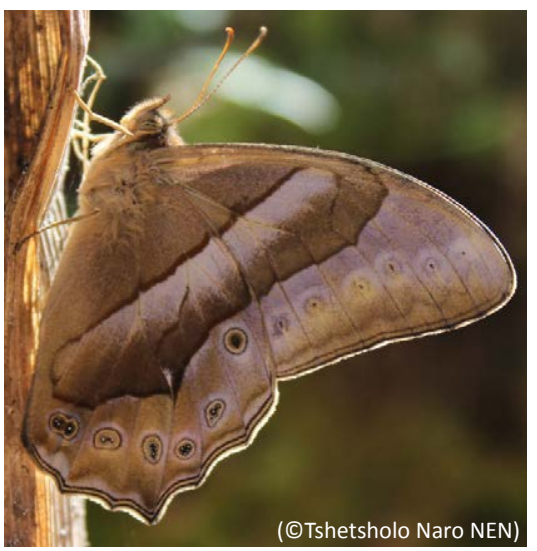

Image 150. Common Red Forester Lethe mekara mekara

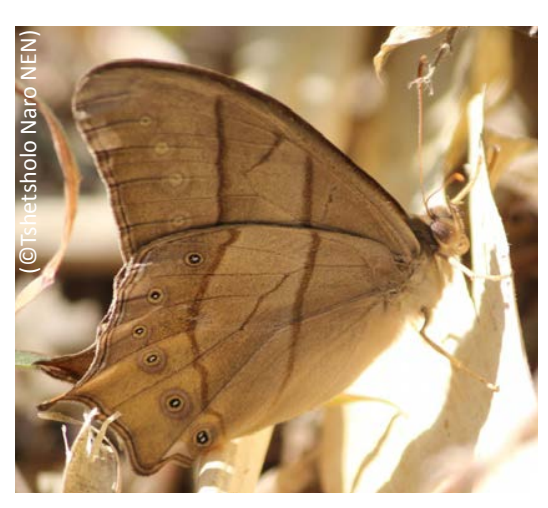

Image 152. Bamboo Forester Lethe cf. kansa

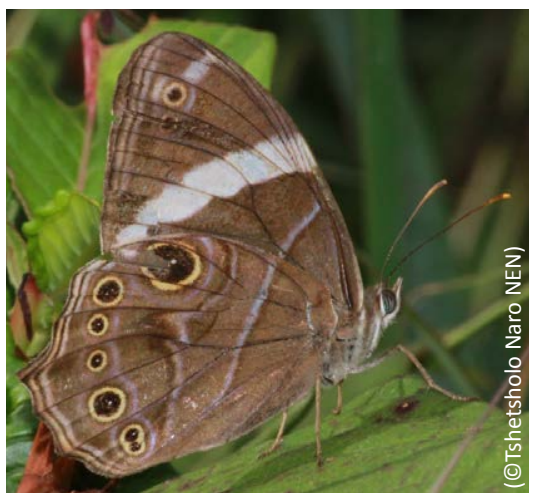

Image 146. Banded Treebrown Lethe confusa confusa

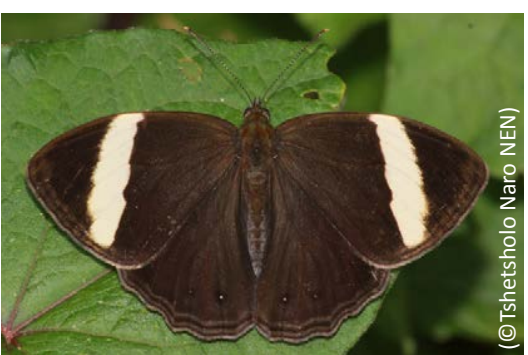

Image 148. Straight-Banded Treebrown Lethe verma sintica

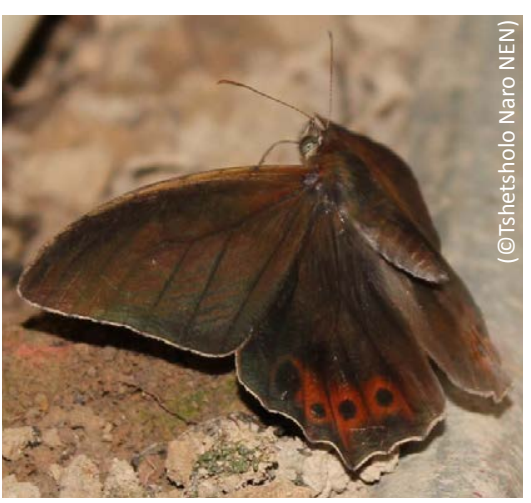

Image 150. Common Red Forester Lethe mekara mekara

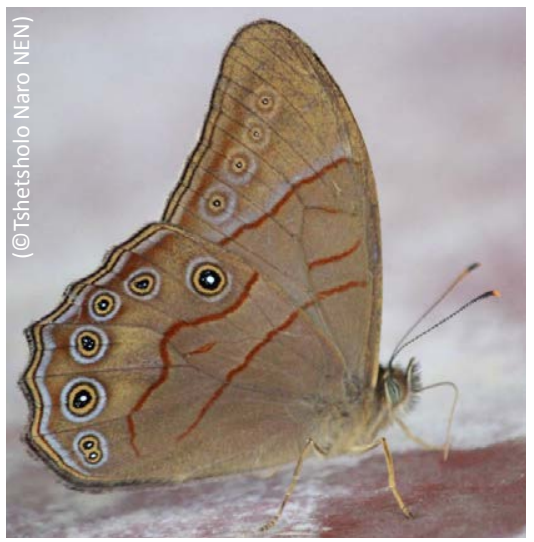

Image 153. Pale Forester Lethe latiaris latiaris

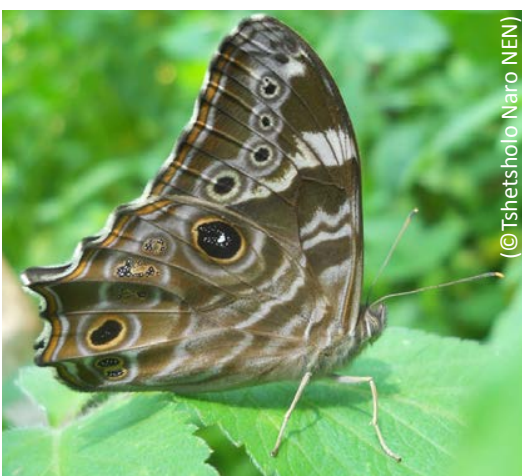

Image 147. Common Treebrown Lethe rohria rohria

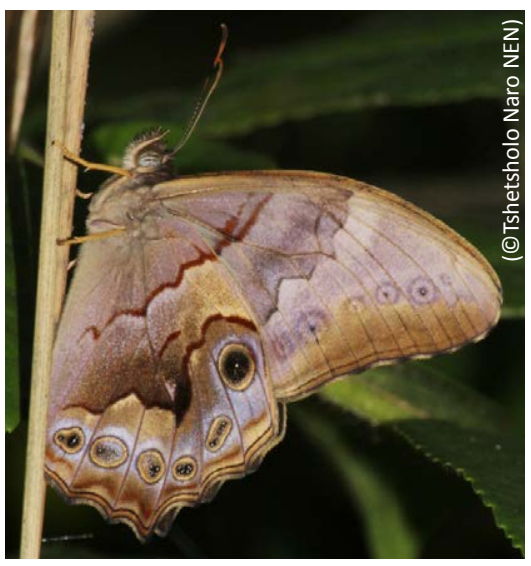

Image 149. Angled Red Forester Lethe chandica chandica

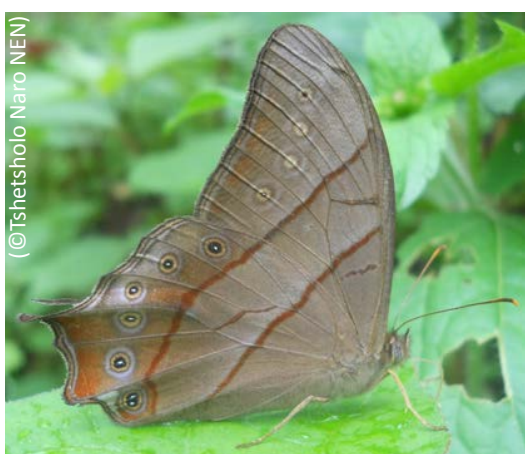

Image 151. Tailed Red Forester Lethe sinorix sinorix

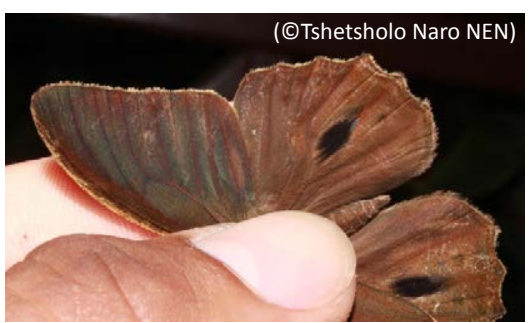

Image 153. Pale Forester Lethe latiaris latiaris 


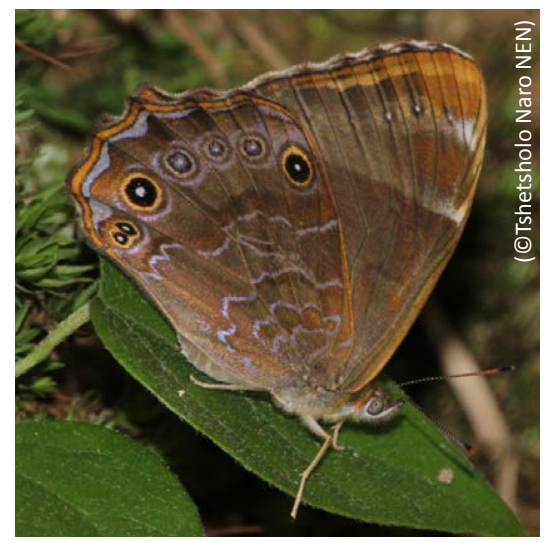

Image 154. Common Woodbrown Lethe sidonis

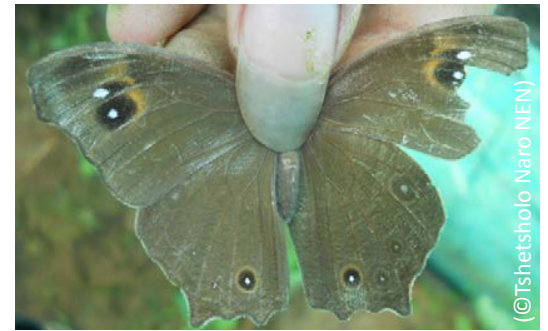

Image 156. Common Evening Brown Melanitis leda leda

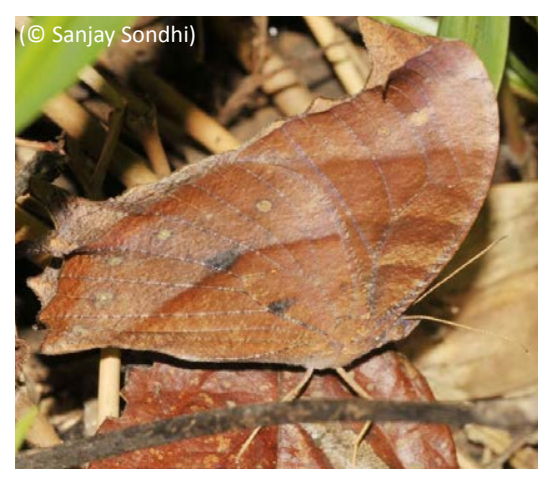

Image 158. Great Evening Brown Melanitis zitenius zitenius

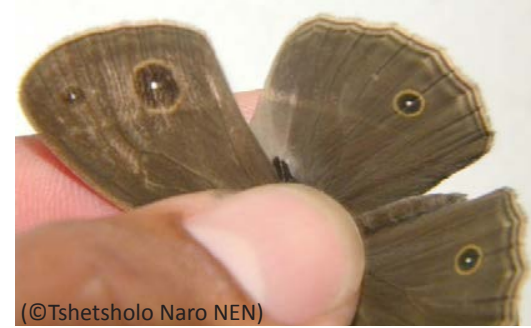

Image 159. White-line Brushbrown Heteropsis malsara

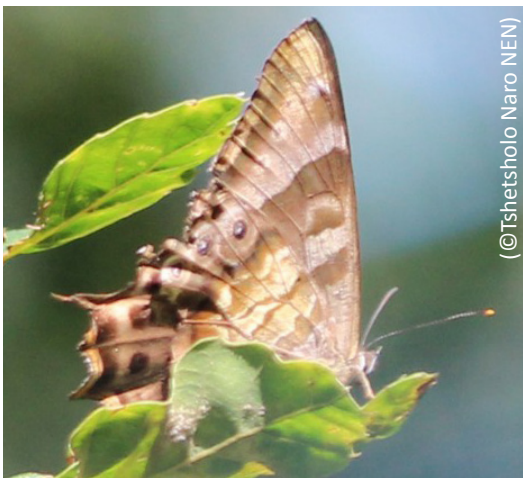

Image 155. Lilafork Lethe cf. sura

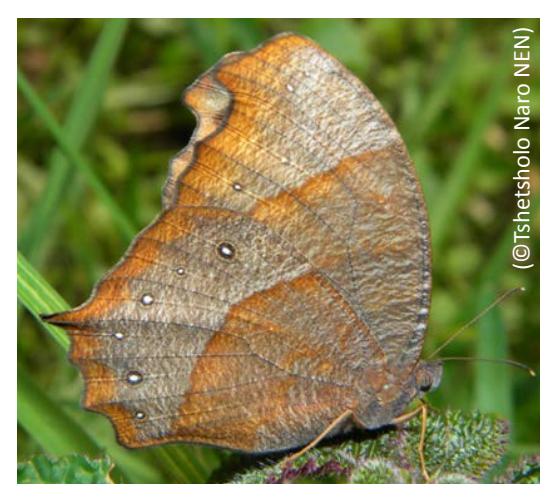

Image 157. Dark Evening Brown Melanitis phedima bela

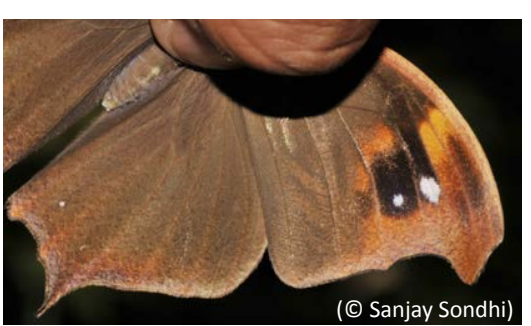

Image 158. Great Evening Brown Melanitis zitenius zitenius

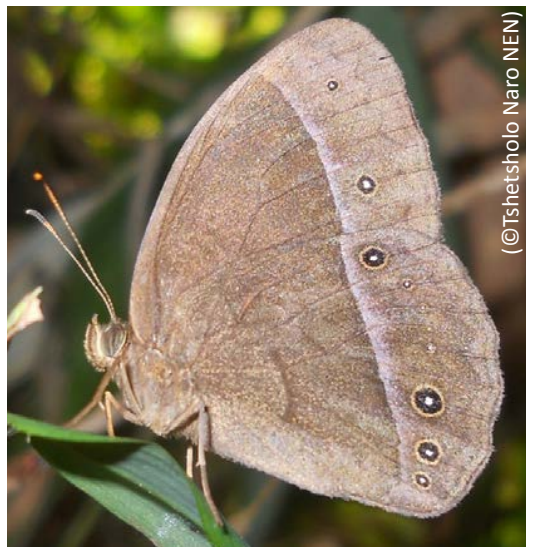

Image 160. Lilacine Bushbrown

Mycalesis francisca sanatana

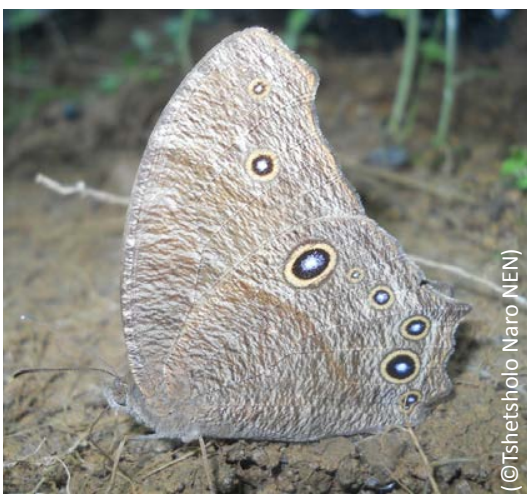

Image 156. Common Evening Brown Melanitis leda leda

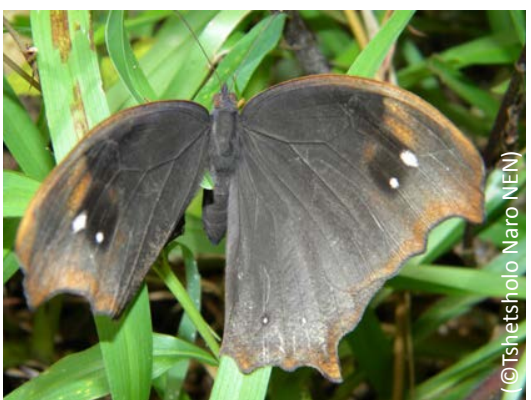

Image 157. Dark Evening Brown Melanitis phedima bela

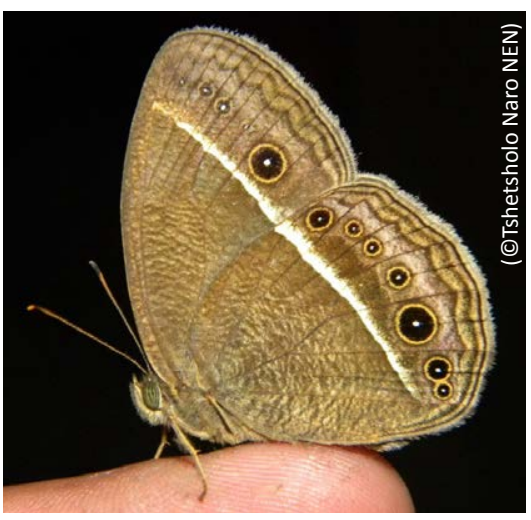

Image 159. White-line Brushbrown Heteropsis malsara

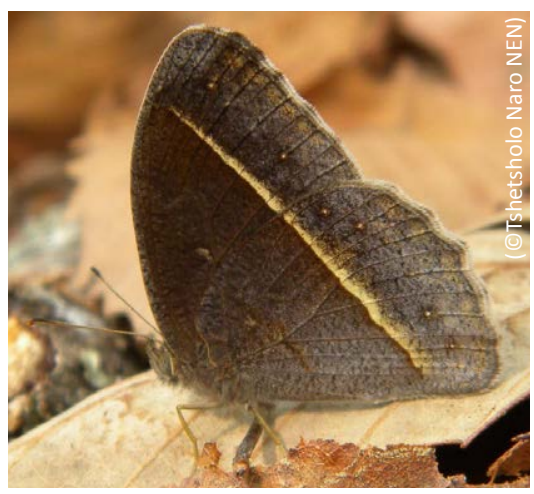

Image 161. Lepcha Brushbrown Mycalesis lepcha kohimensis 


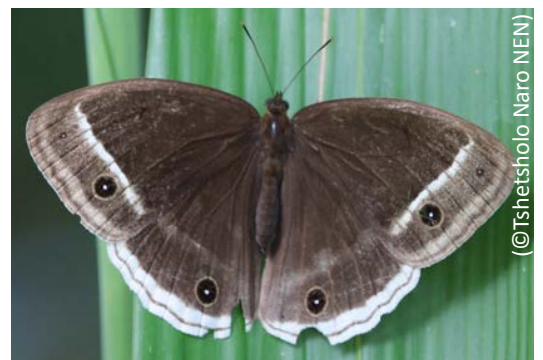

Image 162. White-edged Busgbrown Mycalesis mestra sadona

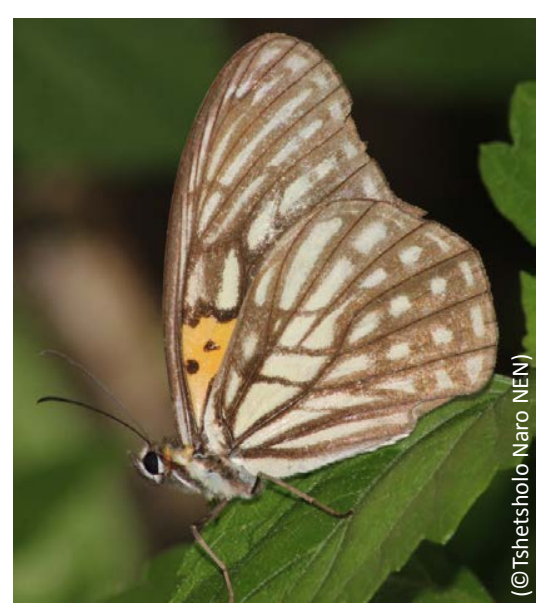

Image 164. Tiger Brown Orinoma damaris damaris

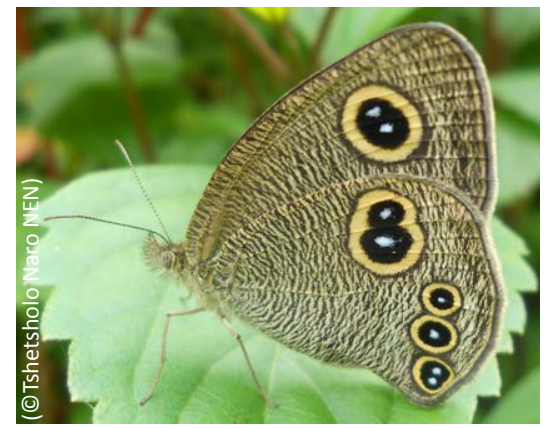

Image 167. Himalayan Five-ring Ypthima sakra sakra

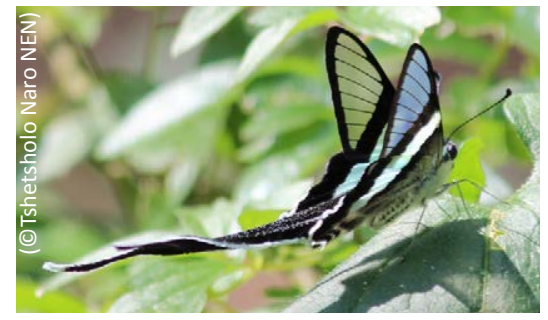

Image 169. Green Dragontail Lamproptera meges indistincta

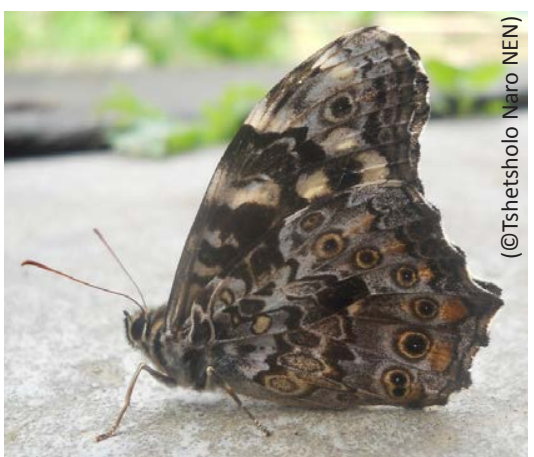

Image 163. Veined Labyrinth Neope pulaha pulaha

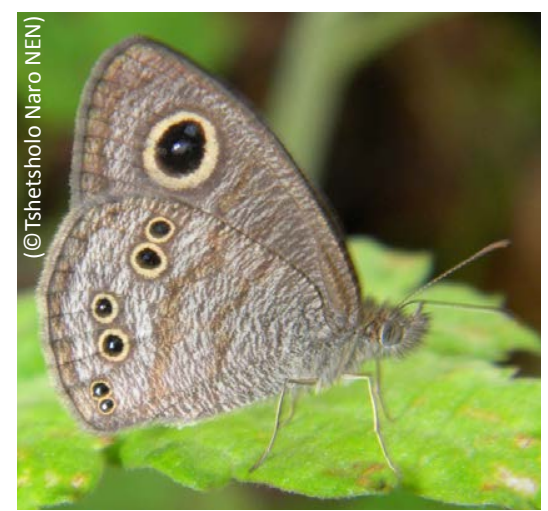

Image 165. Common Five-ring Ypthima baldus baldus

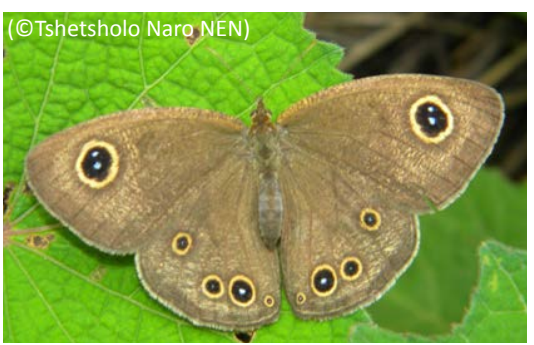

Image 167. Himalayan Five-ring Ypthima sakra sakra

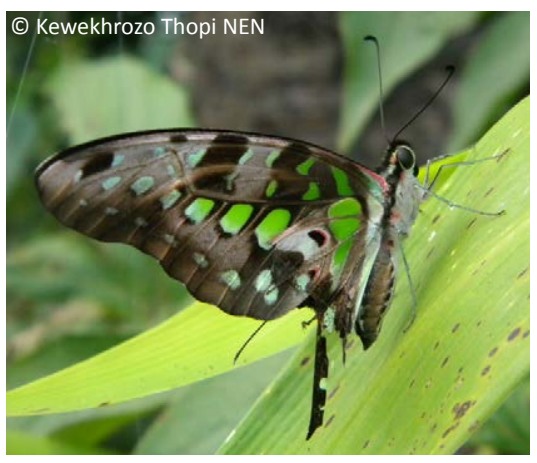

Image 170. Tailed Jay Graphium agamemnon agamemnon

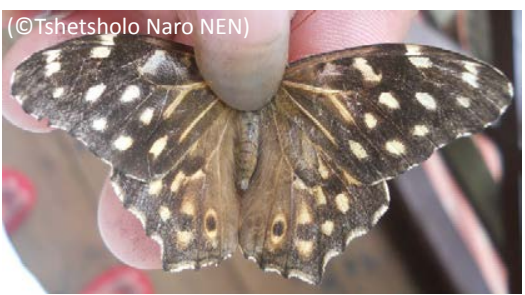

Image 163. Veined Labyrinth Neope pulaha pulaha

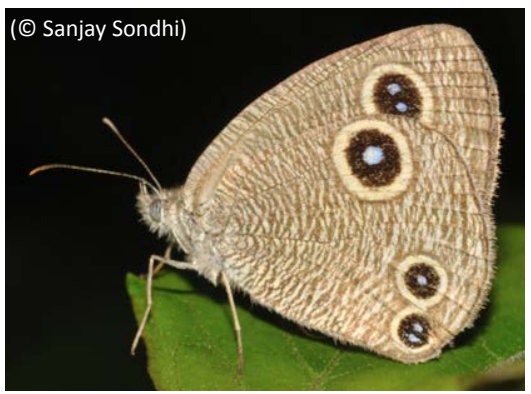

Image 166. Newar Three-ring Ypthima cf. newara newara

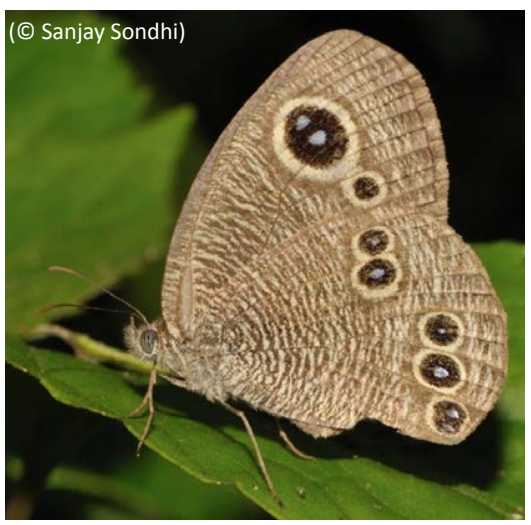

Image 168. Ypthima spp.

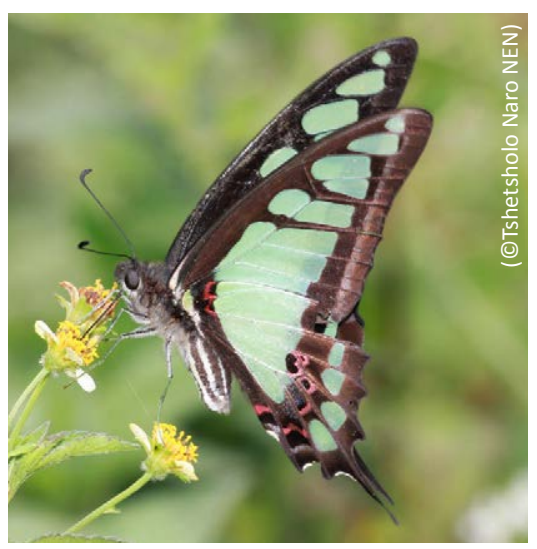

Image 171. Glassy Bluebottle Graphium cloanthus cloanthus 


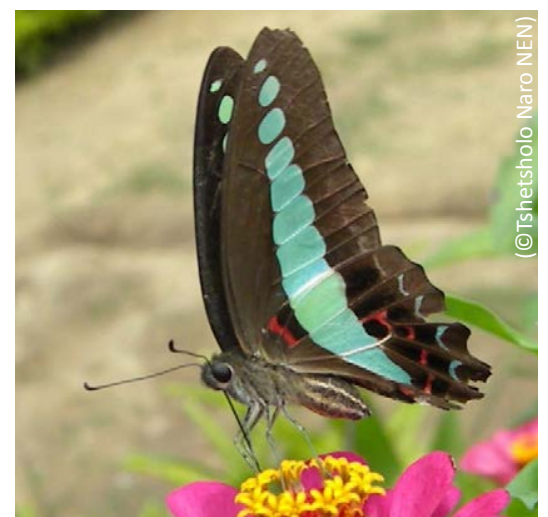

Image 172. Common Bluebottle Graphium sarpedon sarpedon

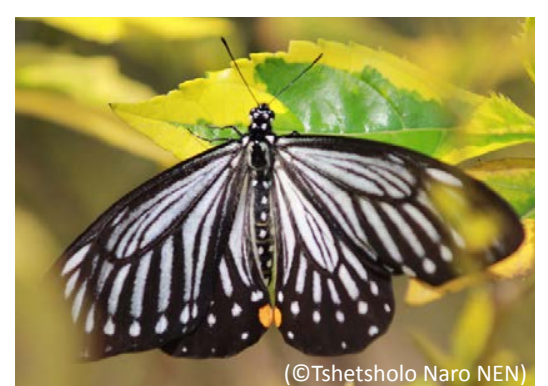

Image 174. Lesser Mime Papilio epycides epycides

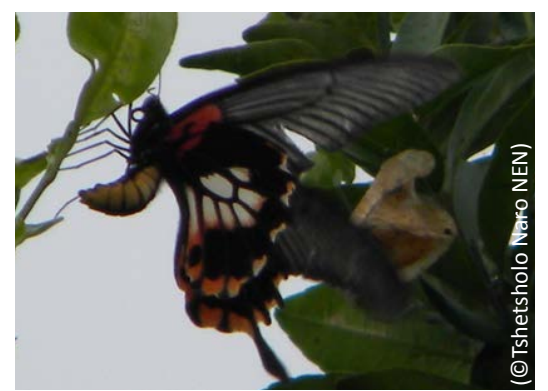

Image 177. Great Mormon Papilio memnon agenor

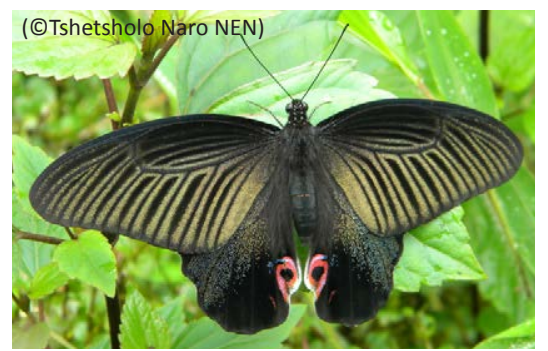

Image 180. Spangle Papilio protenor euprotenor

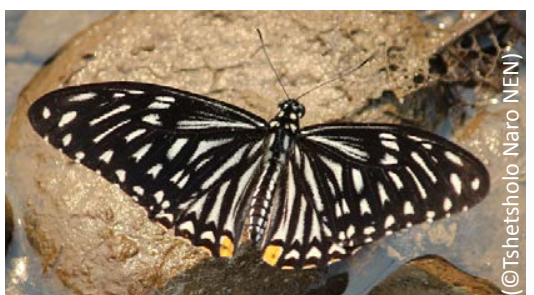

Image 173. Common Mime Papilio clytia clytia

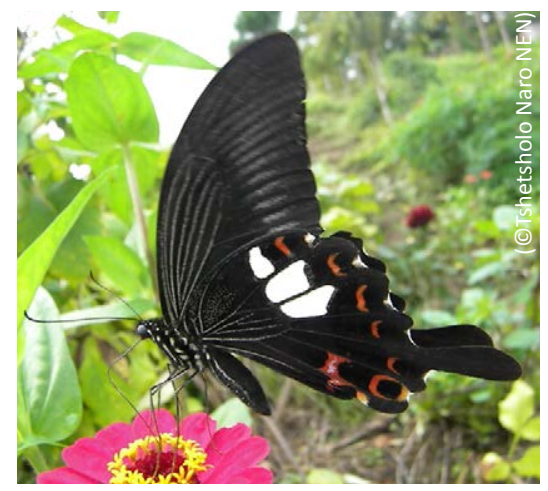

Image 175. Red Helen Papilio helenus helenus

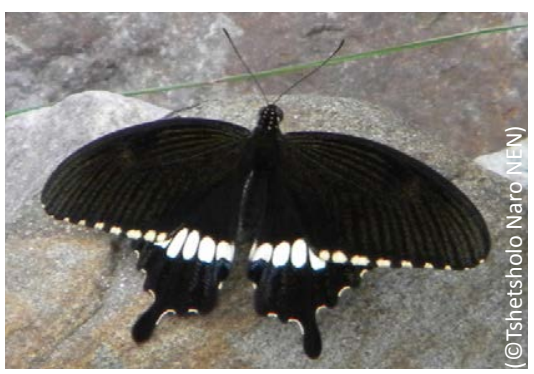

Image 178. Common Mormon Papilio polytes romulus

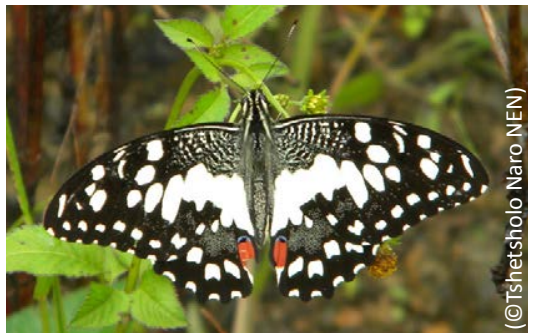

Image 181. Lime Butterfly Papilio demoleus demoleus

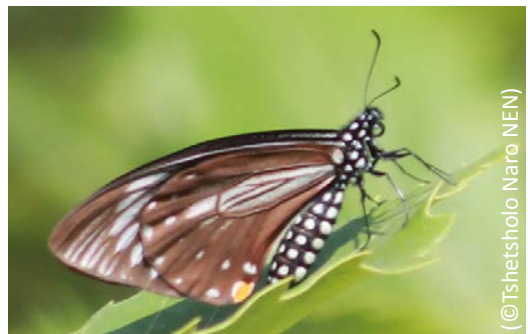

Image 174. Lesser Mime Papilio epycides epycides

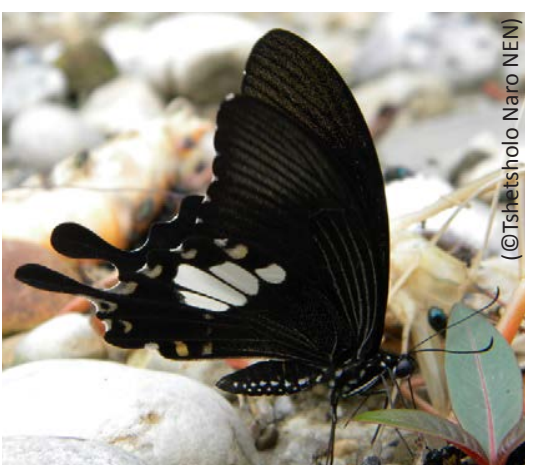

Image 176. Yellow Helen Papilio nephelus chaon

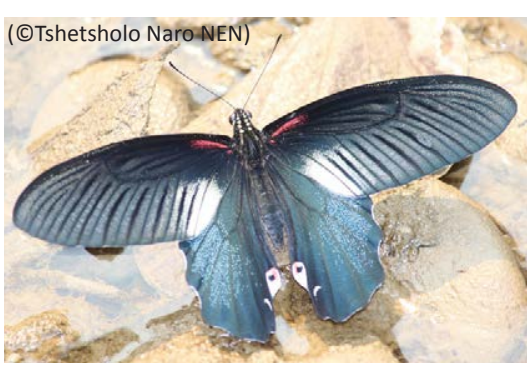

Image 179. Redbreast Papilio alcmenor alcmenor

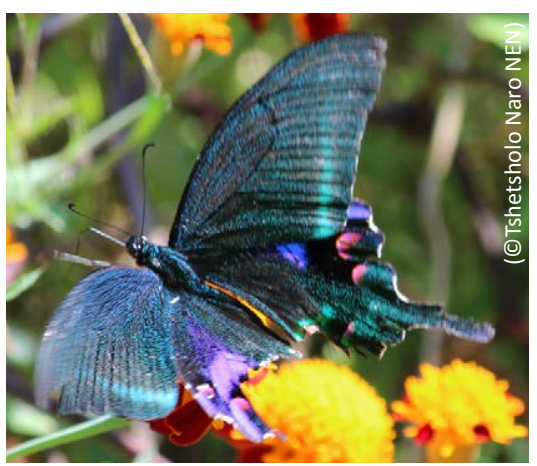

Image 182. Blue Peacock Papilo arcturus arcturus 


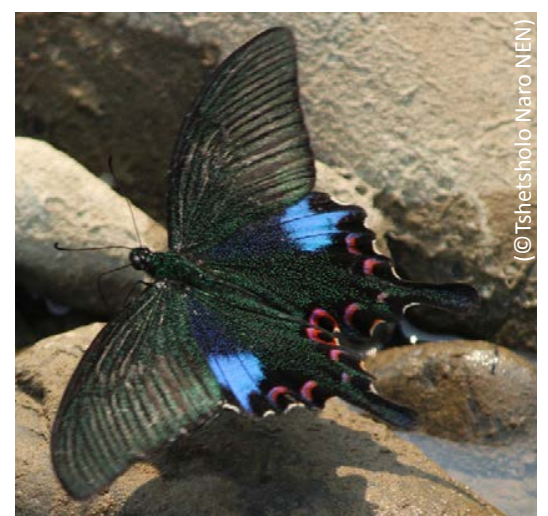

Image 183. Common Peacock Papilio bianor ganesa

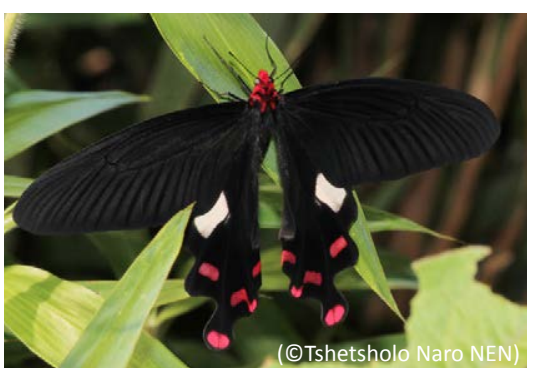

Image 186. Common Windmill

Byasa polyeuctes polyeuctes

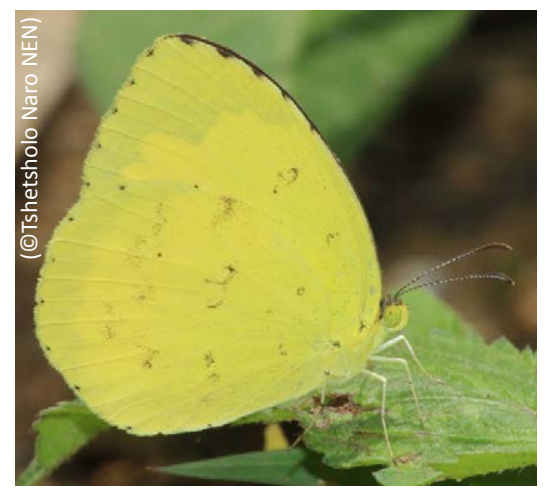

Image 190. Common Grass Yellow Eurema hecabe hecabe

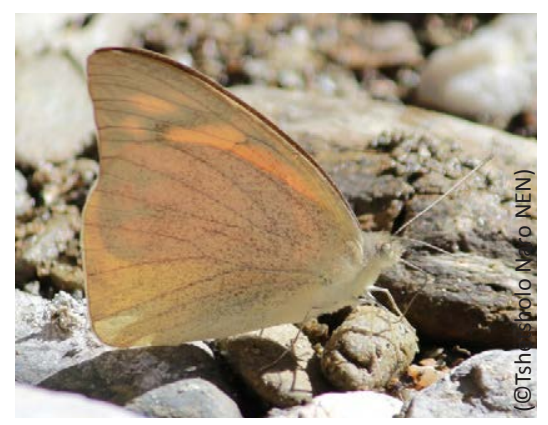

Image 193. Orange Albatross Appias galba

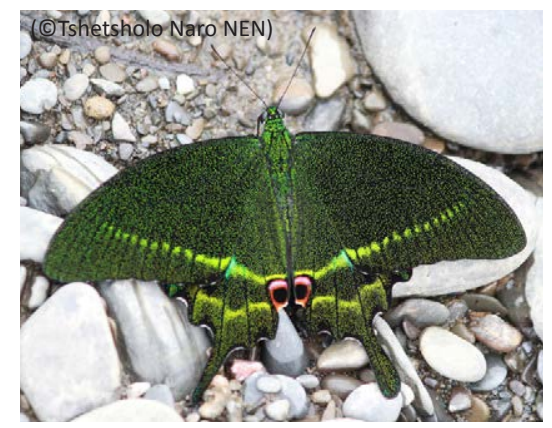

Image 184. Paris Peacock Papilio paris paris

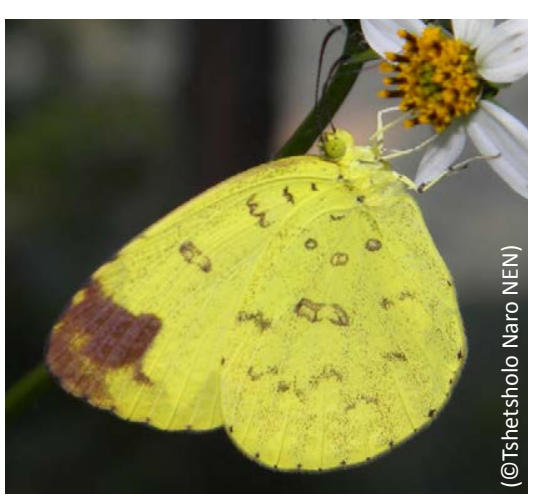

Image 188. Three-spot Grass Yellow Eurema blanda silhetana

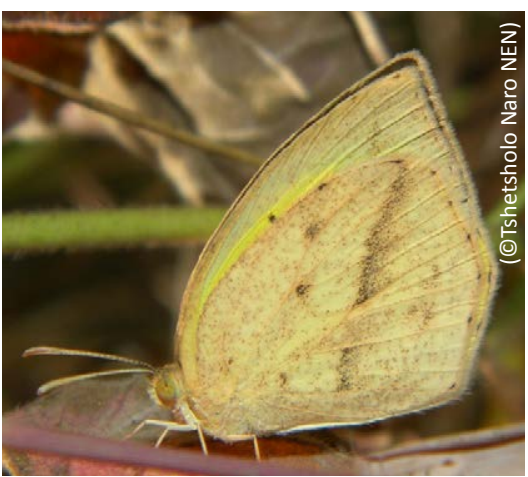

Image 191. Spotless Grass Yellow Eurema laeta sikkima

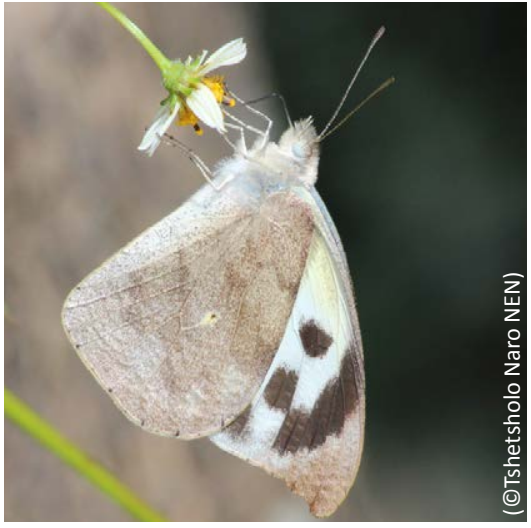

Image 194. Spot Puffin Appias lalage lalage

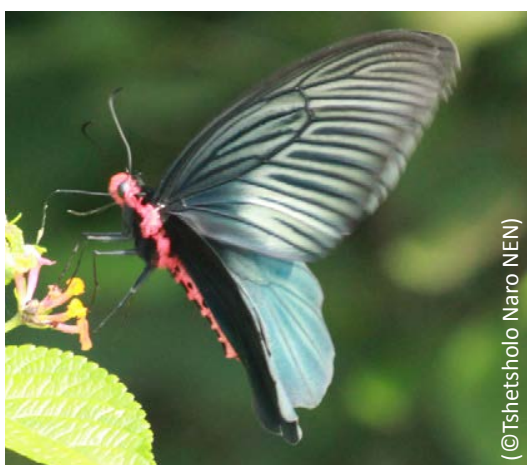

Image 185. Common Batwing Atrophaneura varuna astorion

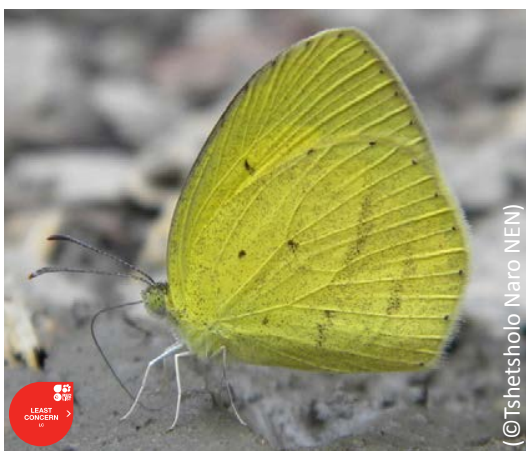

Image 189. Small Grass Yellow Eurema brigitta rubella

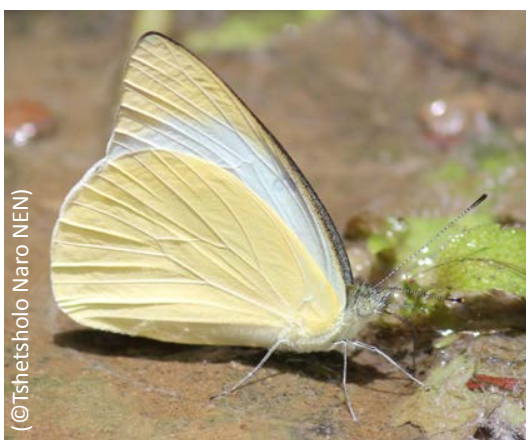

Image 192. Common Albatross Appias albina darada

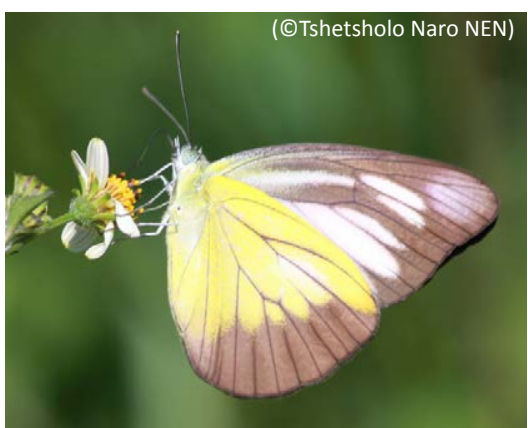

Image 195. Chocolate Albatross Appias lyncida eleonora 


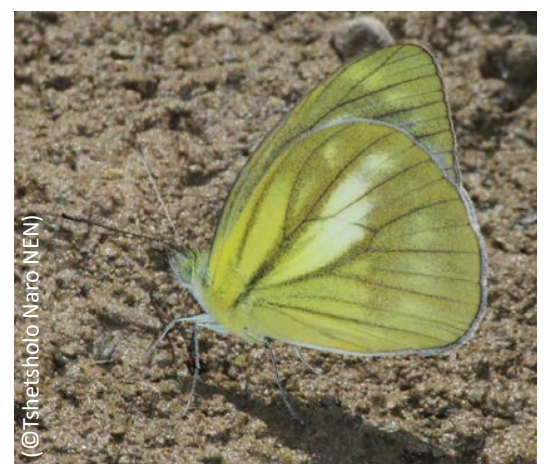

Image 196. Lesser Gull Cepora nadina nadina

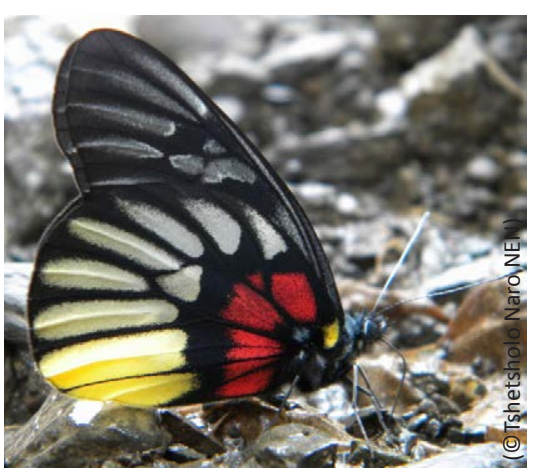

Image 199. Red-breast Jezebel Delias acalis pyramus

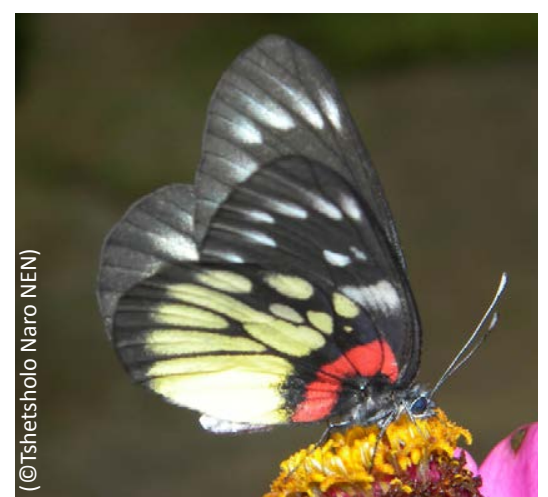

Image 202. Red-base Jezebel Delias pasithoe pasithoe

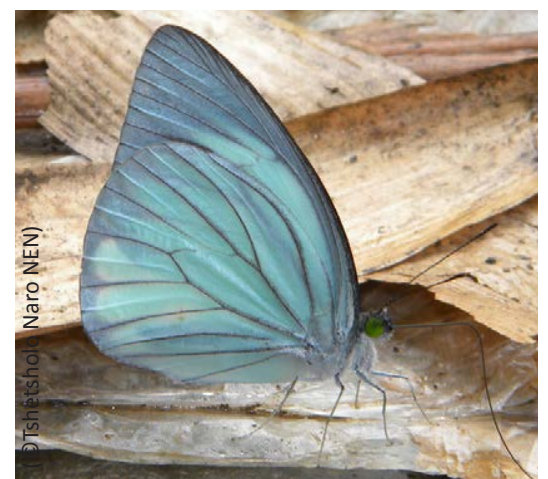

Image 205. Pale Wanderer Pareronia avatar

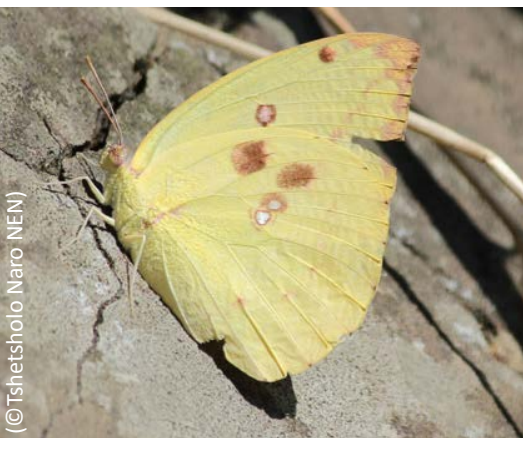

Image 197. Common Emigrant Catopsilia pomona pomona

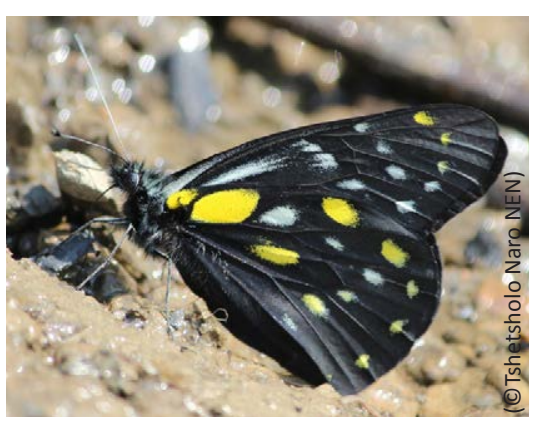

Image 200. Hill Jezebel Delias belladonna lugens

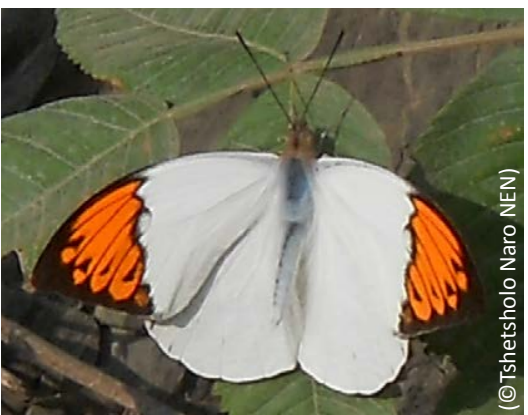

Image 203. Great Orange-tip Hebomoia glaucippe glaucippe

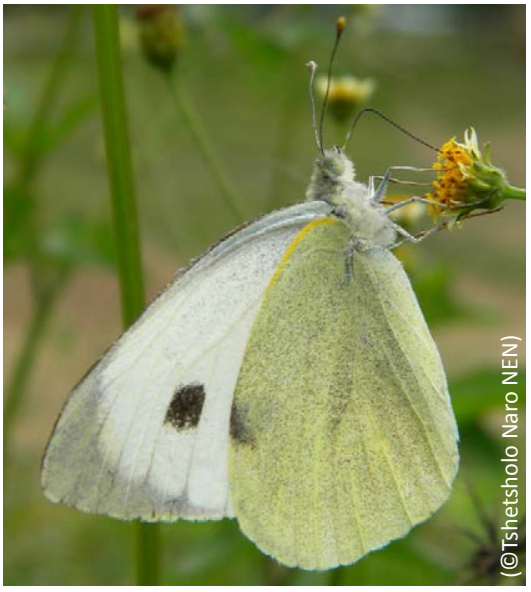

Image 206. Large Cabbage White Pieris brassicae nepalensis

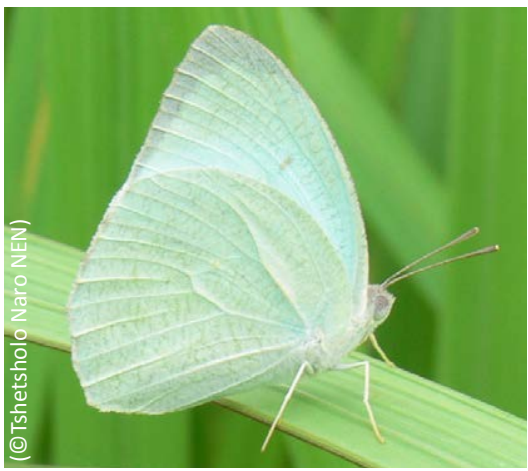

Image 198. Mottled Emigrant Catopsilia pyranthe pyranthe

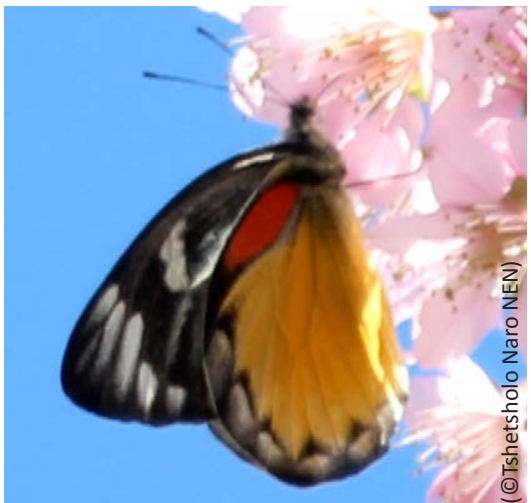

Image 201. Red-spot Jezebel Delias descombesi descombesi

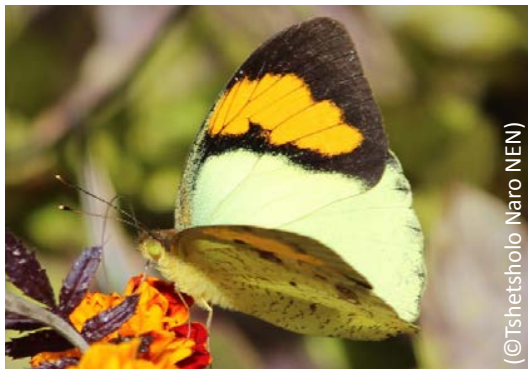

Image 204. Yellow Orange-tip Ixias pyrene familiaris

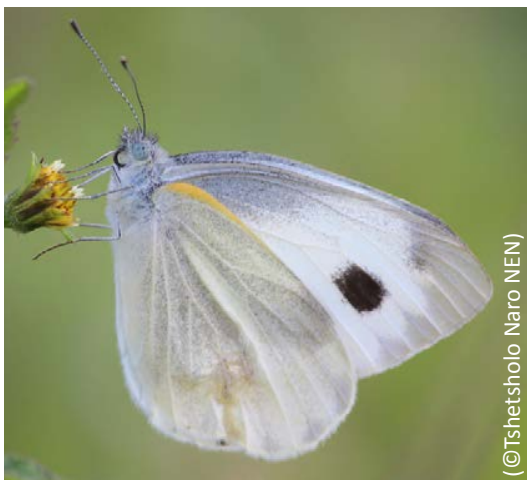

Image 207. Indian Cabbage White Pieris canidia indica 


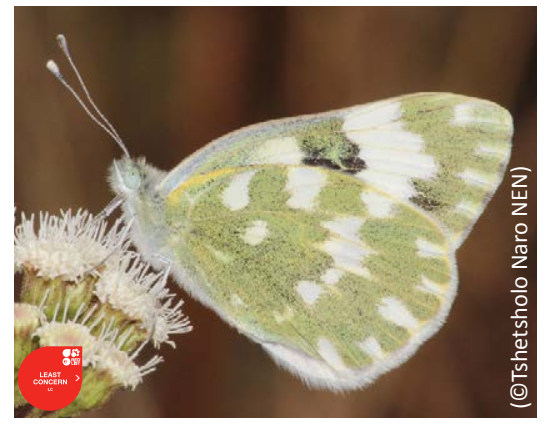

Image 208. Bath White Pontia daplidice moorei

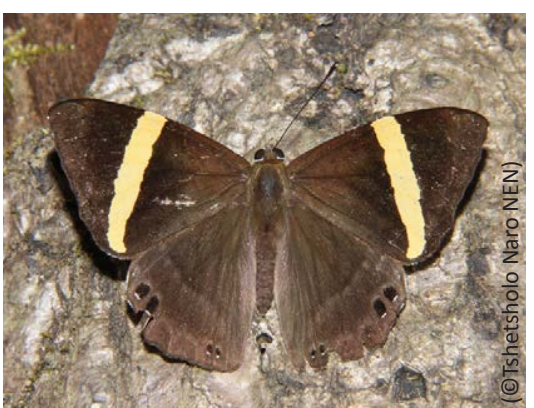

Image 211. Dark Judy Abisara fylla

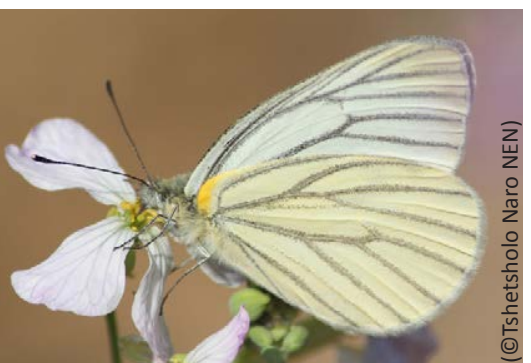

Image 209. Green-viened White Pieris melete ajaka

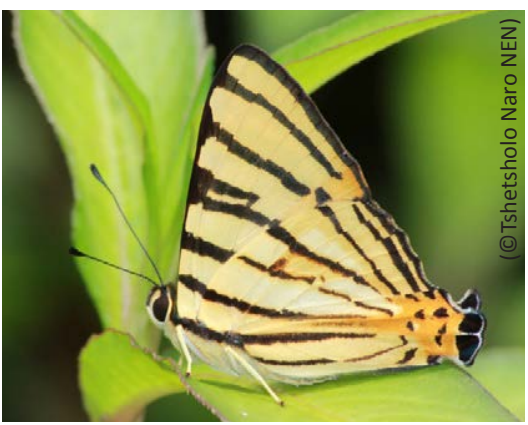

Image 212. Striped Punch Dodona adonira adonira

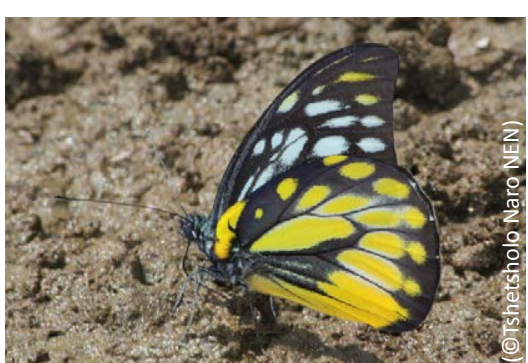

mage 210. Spotted Sawtooth Prioneris thestylis thestylis

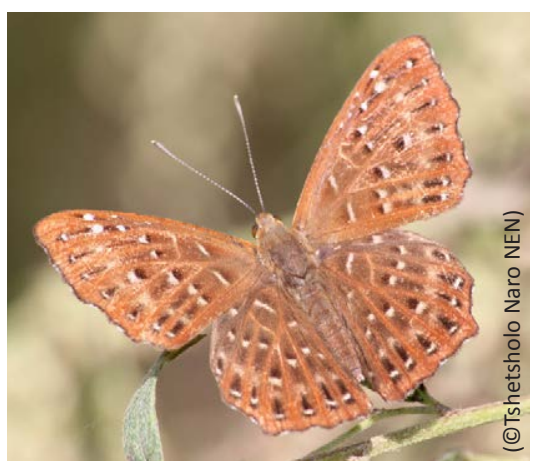

Image 213. Punchinello Zemeros flegyas fleygas 

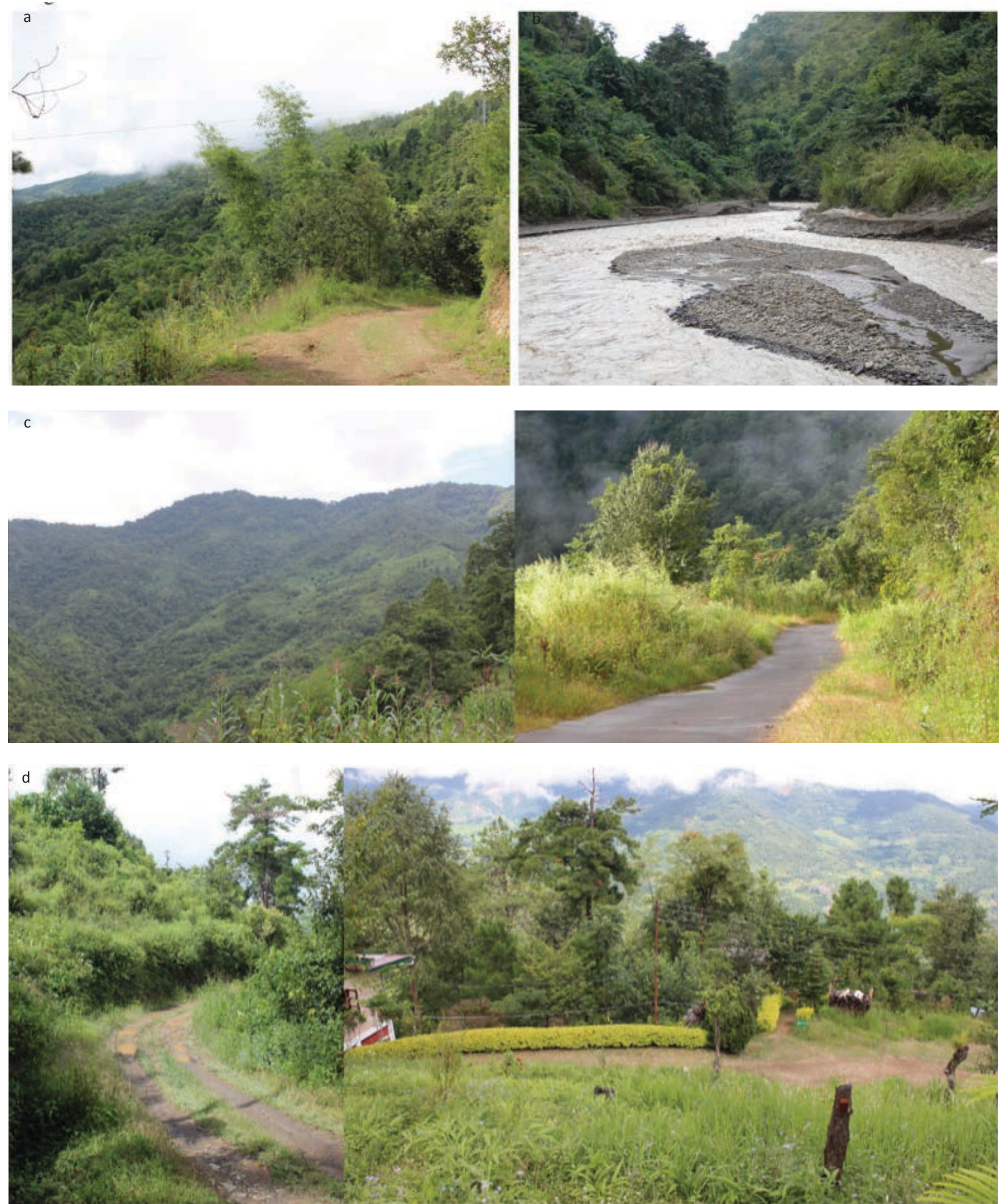

Appendix 1. Primarily visited areas and their habitats. (C) Tshetsholo Naro NEN

a - Ewelu trail; b - Erule River bank; c - View of Thetsumi trail during monsoon; d - View of North East Network (NEN) compound 


\section{EMPOWERING YOUNGSTERS IN CONSERVING BIODIVERSITY - CHIZAMI}

\section{EXPERIENCE}

The Hoolock Gibbon Eco club (HGEC) was formed in 2010. This was the first eco-club to be formed in Nagaland and has been a pioneering effort of an NGO called the North East Network (NEN). The club has 50 children in the age group of 10-14 years from the village of chizami and the neighbouring village of Enhulumi. HGEC was an outcome of a wildlife education program to aid in mitigating wild animal hunting titled "under the canopy" that Dusty foot Productions (www.dustyfootindia.com) and 90 wild (payalmolur.blogspot.in) conducted in 2009. While filming a story on orphaned bear cubs, the Dusty Foot Production team came across rampant hunting and selling of wild meat in northeastern india. This led them to team up with a wildlife education group 40 wild workshops to create an education program and curriculum to shift the focus from hunting to research, photography and enquiry. North East Network and its tryst with wildlife education and conservation began in 2009 when approached by the Rita Banerji (Dusty Foot Productions) and Payal Molur (Go Wild).

North East Network (www.northeastwetwork. org) is a woman's rights organization in northeast india, established in 1995. NEN's role has been that of a facilitator to empower women of northeast around issues of livelihood, health, conflict and governance through capacity building, awareness raising, networking, research and advocacy. North East Network and its tryst with wildlife education and conservation began in 2009 when approached by the Rita Banerji (Dusty Foot Productions) and payal Molur ( 90 Wild) to be the local partwer. Titli trust (www.titlitrust.com), was also brought in to bring a new dimension to the scientific education program. From there they have expanded the program exponentially and now have trainers and clubs in three districts of Nagaland.

The teachers and children trained in Nagaland, have not only understood the importance of conserving their forests but also have taken it to the next stage of maintaining biodiversity registers and cataloguing the animals that are around them in a scientific manner.

over the past four years the club has been churning out a series of wildlife publications in the form of posters, booklets, journal articles and popular articles:

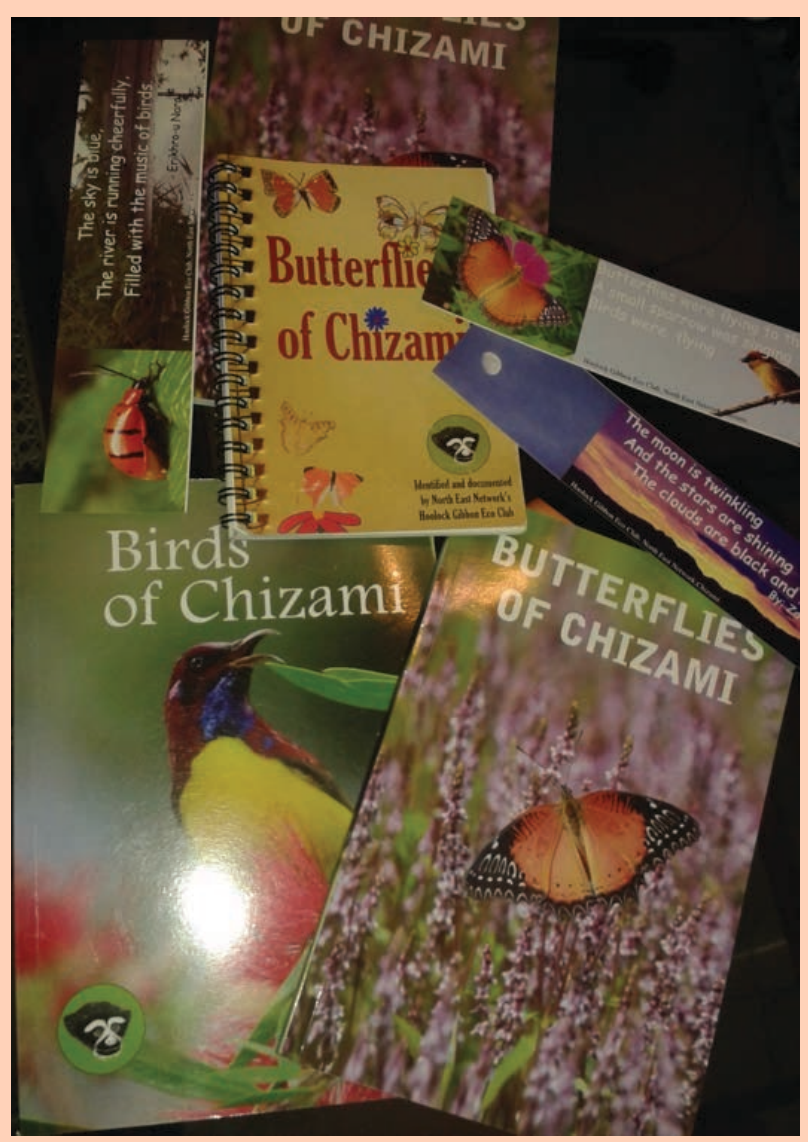

A few of the publications of $H C E C$

First and second edition booklets with 171 and 217 species of butterflies of chizami respectively (2012 and 2014)

- A booklet on the Birds of Chizami (2014)

- Posters on wildlife of Chizami, Birds of Chizami and Butterflies and Moths of Chizami

Naro, T. (2012). Sighting of Aglais cashmirensis aesis Fruhstorfer, 1912 (Nymphalidae) from Nagaland, India. Journal of Threatened Taxa 4(4): 2534-2535; http://dx.doi.org/10.1160g/ J0TT.03019.2534-5

- Naro, T. E S. Sondhi (2013). Sightings of Bath White Pontia daplidice moorei Röber, 1907 (Lepidoptera: Pieridae: Pierinae: Pierini) from Arunachal Pradesh and Nagaland, India. Journal of Threatened Taxa 5(7): 4122-4124; http://dx.doi. org/10.11609/J0TT.03308.4122-4

Payal Molur payal.bmolur@gmail.com 

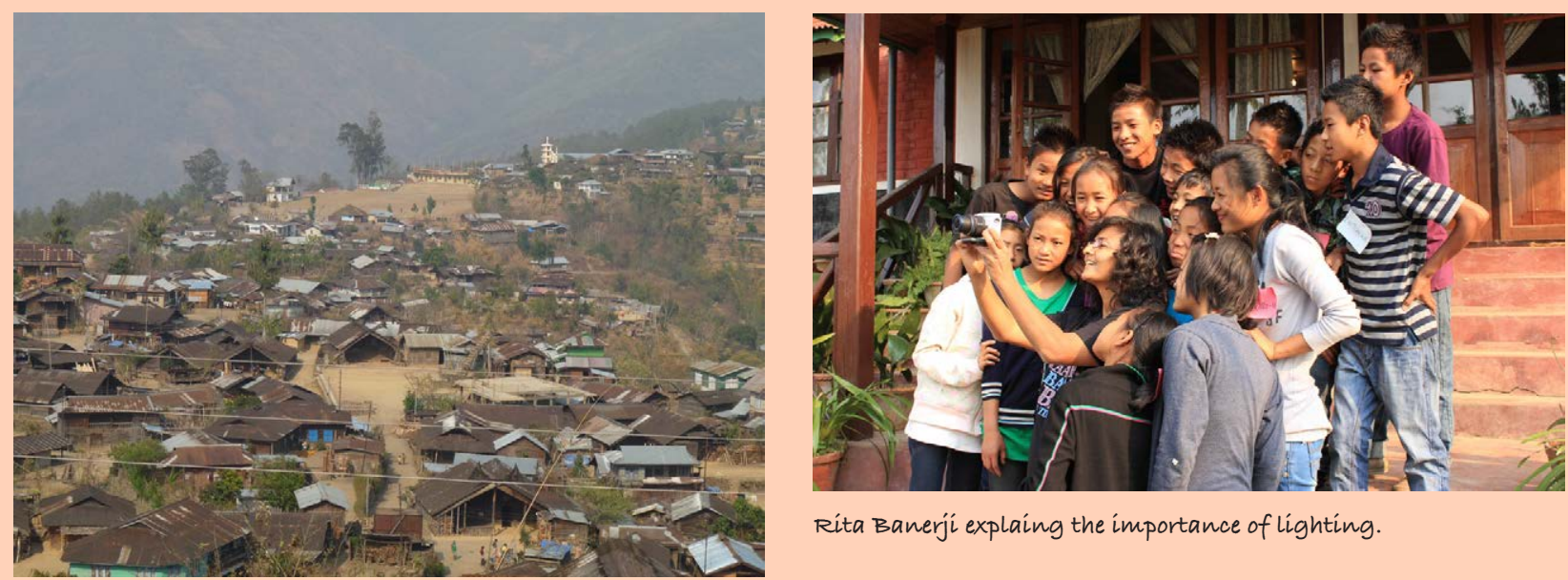

Chizami village, Phek, Nagaland

Rita Banerji explaing the importance of lighting
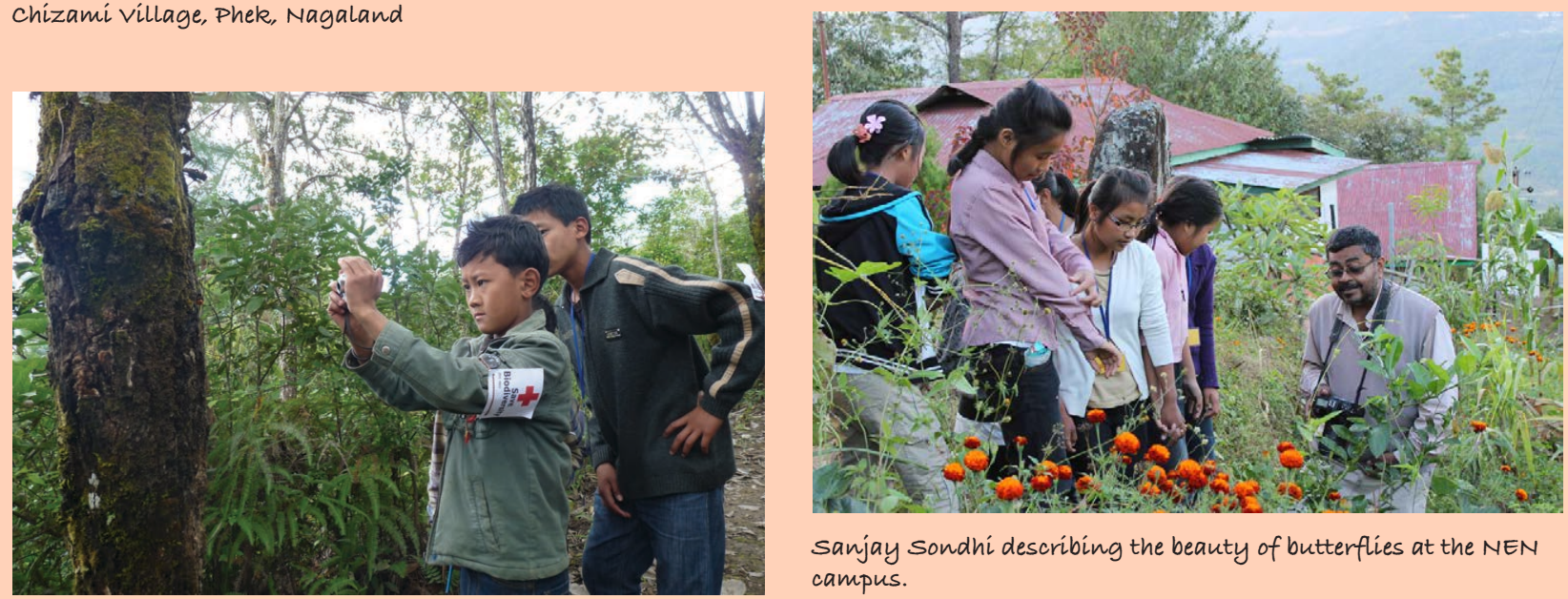

sanjay sondhi describing the beauty of butterflies at the NEN campus.

understanding macro photography techniques
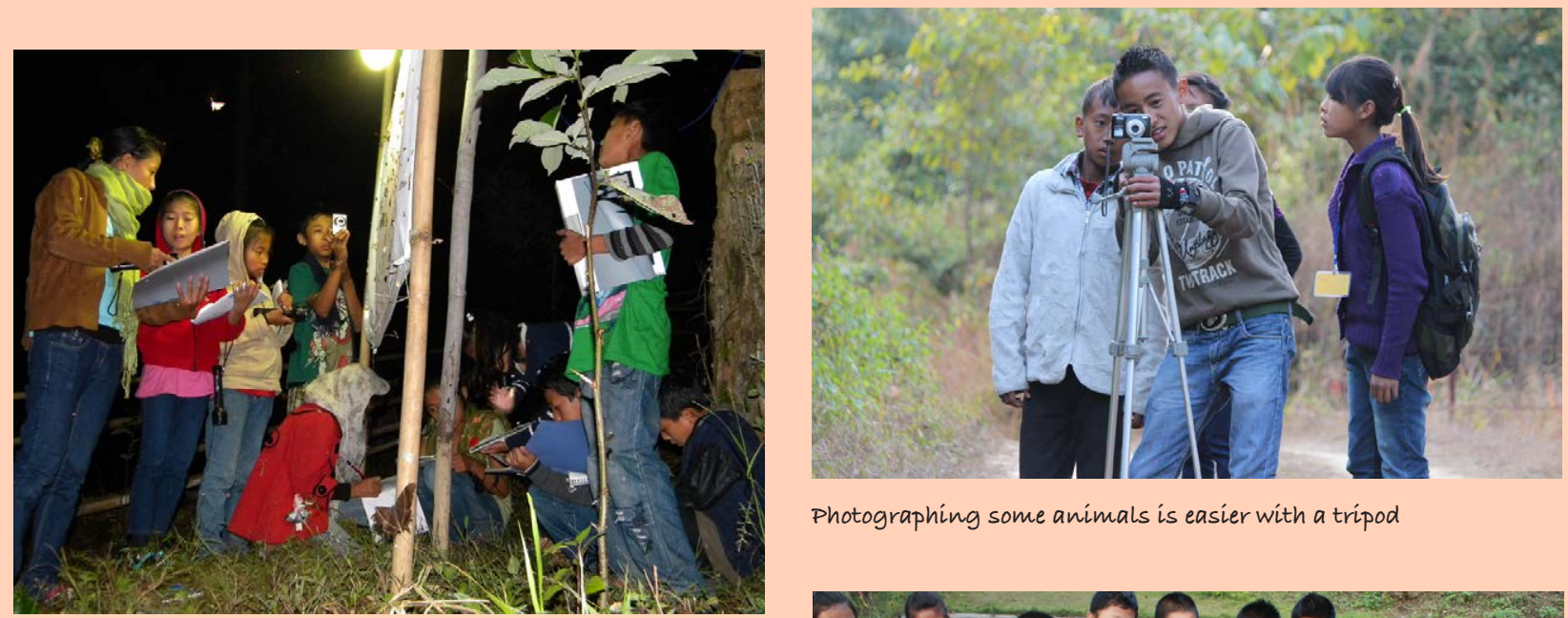

Photographing some animals is easier with a tripod

Diligently cataloging moths

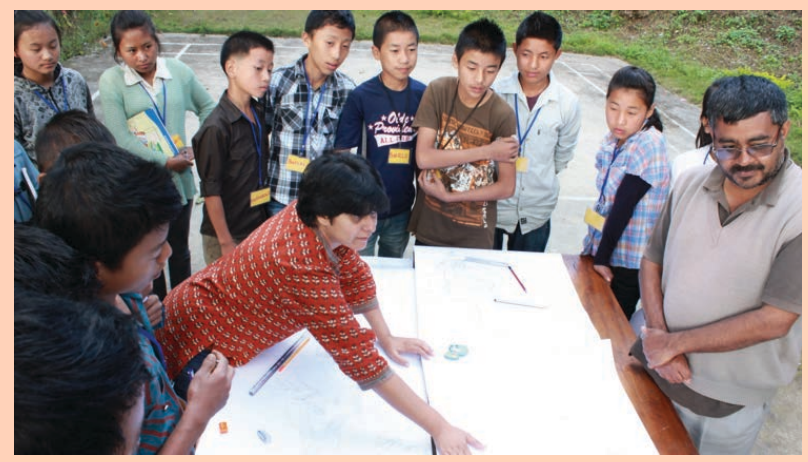

Payal Molur explaining how to map an area 